\title{
Clustering and frequency of mutations in the retinal guanylate cyclase (GUCY2D) gene in patients with dominant cone-rod dystrophies
}

Annette M Payne, Alex G Morris, Susan M Downes, Samantha Johnson, Alan C Bird, Anthony T Moore, Shomi S Bhattacharya, David M Hunt

EDITOR-Guanylate cyclase (retGC-1) is a key enzyme in the recovery phase of phototransduction in both cone and rod photoreceptor cells. ${ }^{1}$ Upon excitation by a photon of light, an enzymatic cascade of events occurs which leads to the hydrolysis of cGMP and the closure of the cGMP gated cation channels. This results in hyperpolarisation of the plasma membrane and the generation of a signal higher up in the visual pathway. Upon closure of the ion channels, the cytosolic levels of $\mathrm{Ca}^{2+}$ decrease because export by the $\mathrm{Na}^{+}, \mathrm{K}^{+}, \mathrm{Ca}^{2+}$ exchanger continues. This reduced $\mathrm{Ca}^{2+}$ concentration results in the activation of retGC by activating proteins (GCAPs) and the increased conversion of GTP to cGMP, thus restoring the level of cGMP in the photoreceptors to their dark level.

Mutations in GUCY2D, the gene encoding retGC-1, are a cause of Leber congenital amaurosis (LCA1), a recessive condition which manifests itself either at birth or during the first few months of life as total or near total blindness. ${ }^{2}{ }^{3}$ Recently, we identified mutations in GUCY2D in four British families with autosomal dominant cone-rod dystrophy (ADCORD).$^{4}$ Subsequent to this, mutations in this gene were shown to be responsible for ADCORD in a French, ${ }^{5}$ a Swiss, ${ }^{6}$ and a Norwegian $^{7}$ family. In all seven families, the mutations are either in the same or in adjacent codons in a highly conserved region of the protein. In our four families and in the Swiss and Norwegian families, mutations were found in either codon 837 or $838,{ }^{467}$ whereas codons 837-839 each encode for an amino acid substitution in the French family. ${ }^{5}$

In order to determine whether ADCORD arising from mutations in GUCY2D are restricted to these codons and how important these mutations are to autosomal retinal disease in general, we have screened an additional group of unrelated patients diagnosed with autosomal dominant macular dystrophy or autosomal dominant cone or cone-rod dystrophy.

\section{Methods}

MUTATION SCREENING

The coding exons of GUCY2D were amplified using the intronic primers and annealing temperatures essentially as described previously ${ }^{2}$ and subjected to heteroduplex analysis. ${ }^{8}$ All fragments exhibiting band shifts were directly sequenced using the PRISM ${ }^{\mathrm{TM}}$ Ready Reaction Sequencing Kit (Perkin Elmer PE Biosystems), and the products were visualised on an ABI Model 373 DNA sequencer.

\section{HAPLOTYPE ANALYSIS}

One of each primer pair was end labelled with $10 \mu \mathrm{Ci}$ of $\left[\gamma^{32} \mathrm{P}\right] \mathrm{ATP}$ using polynucleotidyl kinase for 30 minutes at $37^{\circ} \mathrm{C}$, followed by 10 minutes at $65^{\circ} \mathrm{C}$. PCR was carried out using $1.5 \mathrm{mmol} / 1 \mathrm{MgCl}_{2}, 0.2 \mathrm{mmol} / 1 \mathrm{dNTP}$ mix, $\mathrm{KCl}$ buffer, $0.05 \mathrm{U} / \mathrm{ml} \mathrm{Taq}$ polymerase (Bioline), 0.1 $\mathrm{mmol} / 1$ of each primer, and 0.1-0.2 $\mu \mathrm{g}$ of genomic DNA. The amplification protocol was $94^{\circ} \mathrm{C}$ for three minutes, followed by 35 cycles at $94^{\circ} \mathrm{C}$ for 30 seconds, $56^{\circ} \mathrm{C}$ for 30 seconds, and $72^{\circ} \mathrm{C}$ for 30 seconds. The resulting products were visualised on a $6 \%$ polyacrylamide/urea denaturing gel. The gel was dried down at $80^{\circ} \mathrm{C}$ under vacuum and autoradiographed over $x$ ray film overnight. The DISLAMB program ${ }^{9}$ was used to obtain an estimate of linkage disequilibrium.

\section{Results}

A group of 40 patients, 27 with autosomal dominant macular dystrophy and 13 with autosomal dominant cone or cone-rod dystrophy, was screened for mutations in all exons of GUCY2D. This group was drawn from the same panel that was used in our original study ${ }^{4}$ and is composed of unrelated patients with autosomal dominant macular dystrophies or cone or cone-rod dystrophies attending a Medical Retina Clinic at Moorfields Eye Hospital, London, UK. From this screen, three additional probands with mutations in GUCY2D were identified. Of these, two have the identical R838C substitution to that previously reported $^{4}$ and one has a novel G2586A transition in codon 838 , resulting in an $\mathrm{R} 838 \mathrm{H}$ substitution (fig 1). In addition, a reexamination of our CORD6 family has shown a second mutation, a C2585A transversion again in codon 838 that results in the substitution of arginine by serine (fig 1 ). This mutation is in the adjacent codon to the originally reported E837D substitution. ${ }^{4}$ This is therefore a second example of a $G U C Y 2 D$ disease
Professor Hunt,

d.hunt@ucl.ac.uk 


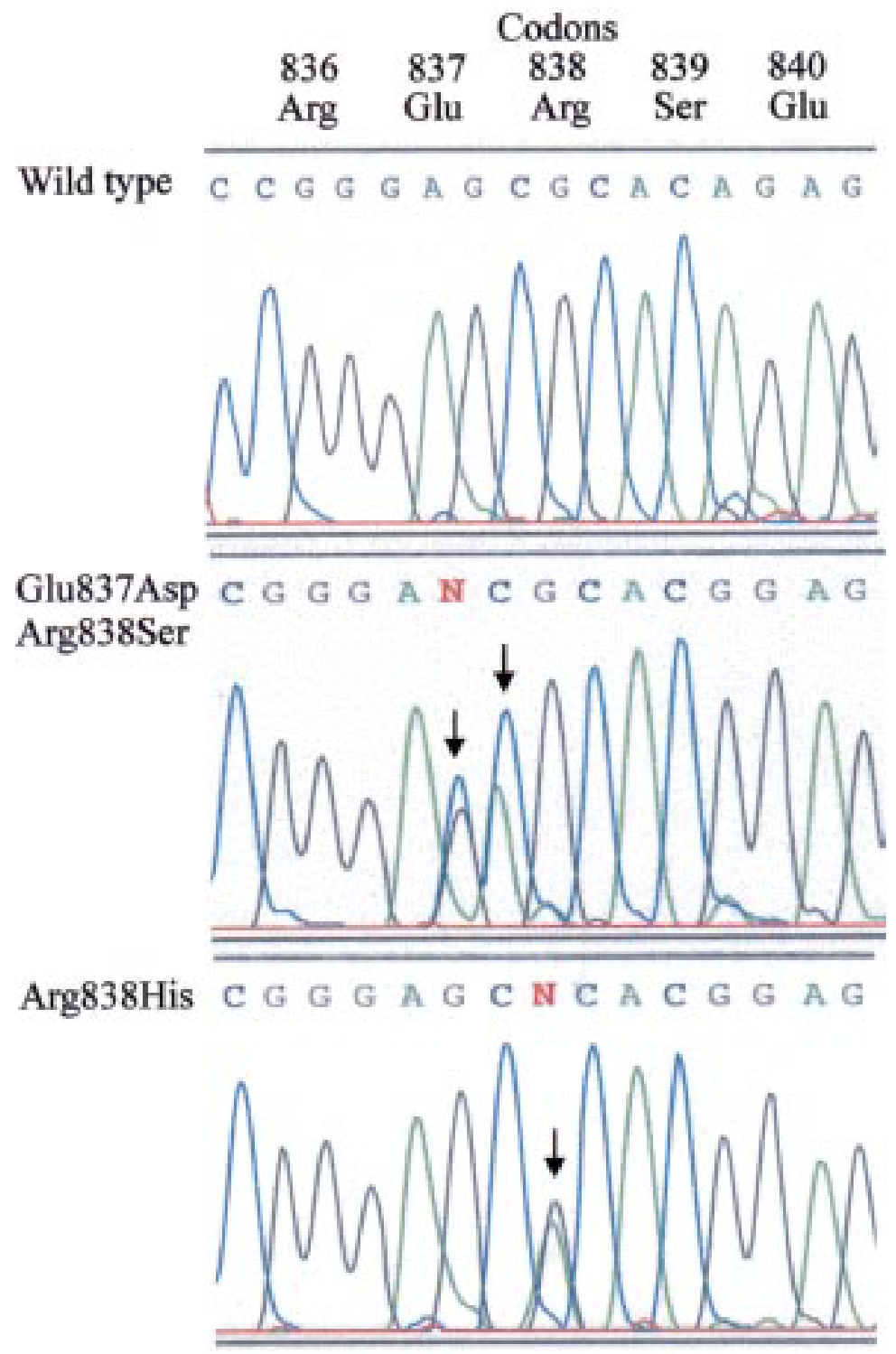

Figure 1 Sequence of exon 13 of retGC1. Heterozygous mutations in adjacent codons of the original CORD 6 family to give the Glu837Asp and Arg838Ser substitutions, and in family 8 to give the Arg838His substitution are shown.

allele carrying multiple mutations. In total, five of our families carry a $\mathrm{C}$ to $\mathrm{T}$ change in codon 838 , one family has a $\mathrm{G}$ to A change in codon 838 , and one family has a double mutation in codons 837 and 838 . All these mutations were confirmed by restriction enzyme digestion, since all cause the loss of a HhaI site. None of these changes were observed in 50 ethnically matched controls. In each case, the diagnosis was confirmed as cone-rod dystrophy ${ }^{410}$ (D Bessant, personal communication). Excluding the original CORD6 family, the 90 unrelated patients screened in this and the previous study therefore yielded a total of six ADCORD patients with mutations in codon 838 of the GUCY2D gene. The above mutations, together with all previously reported mutations, ${ }^{4-7}$ are summarised in table 1.

Haplotype analysis was used to investigate whether there is evidence for relatedness among the five families with the R838C substitution (table 2). In order to determine the
Table 1 Dominant cone-rod mutations in the GUCY2D gene

\begin{tabular}{lll} 
Families/probands & Mutation & Amino acid substitution \\
\hline $1^{\star}$ & G2584C & E837D \\
& C2585A & R838S \\
$2-4 \dagger$ & C2585T & R838C \\
$5-6 \ddagger$ & C2585T & R838C \\
$7 \Phi$ & C2585T & R838C \\
$8 \ddagger$ & G2586A & R838H \\
$9 ₫$ & G2586A & R838H \\
$10^{\star \star}$ & G2584C & E837D \\
& C2585T & R838C \\
& C2589T & T839M
\end{tabular}

$\star$ Original CORD6 family.

†Kelsell et al. ${ }^{4}$

$\ddagger$ This study.

¿Van Ghelue et al. ${ }^{7}$

"Weigell-Weber et al. ${ }^{\circ}$

$\star \star$ Perrault et al. ${ }^{5}$

haplotype of the disease chromosome, additional family members were sought. However, family 5 could not be extended beyond the original proband; the disease associated alleles for markers D17S1881 and D17S1852 could not therefore be fully resolved. All families show some commonality for marker alleles adjacent to the GUCY2D gene; families 2, 3, 5, and 6 share allele 5 at D17S960, families 2, 4, 6 , and possibly 5 share allele 2 at D17S1796, and families 3 to 6 share allele 5 at D17S1881. However, although family 3 shares the same allele as families 4,5 , and 6 at D17S1881, it is unlikely that this is part of a founder haplotype since it would require a double crossover within a very short map interval. An estimate of the likelihood of linkage disequilibrium was obtained from the DISLAMB program ${ }^{9}$ by using allele frequencies obtained from 20 unrelated "married in" subjects in the families. This is significant at the $5 \%$ probability level only for D17S960; the lower estimates of $\lambda$ and $\mathrm{p}$ for the other markers reflect in part the common occurrence of the disease associated alleles in the "married in" subjects.

During our extensive sequence analysis of the GUCY2D gene, a number of single nucleotide polymorphisms (SNPs) were identified as follows: a silent $\mathrm{C} 220 \mathrm{~A}$ transversion in exon 2, coding G227A (A52S) and G227T (A52T) changes in exon 2 (the G227T transversion has been previously reported as a possible sequence polymorphism ${ }^{2}$ ), a silent G2182A transition in exon 10, a coding $\mathrm{T} 2418 \mathrm{~A}(\mathrm{~L} 783 \mathrm{H})$ transversion in exon 12 , a silent G2589A transition in exon 13, a G to A transition in intron 17 , and a $\mathrm{T}$ insertion in intron 19. Unfortunately, in each of our R838C disease families, the more common nucleotide was present at each position. These SNPs do not therefore help to resolve the ancestry of the R838C mutations.

\section{Discussion}

In this and our previous study, ${ }^{4}$ the panel of patients with autosomal dominant disease was drawn at random from unrelated subjects who had received the diagnosis of cone-rod, cone, or macular dystrophy. Our previous study examined 50 members of this panel and identified three probands with an R838C mutation in the GUCY2D gene. In this follow up study of 
Table 2 Microsatellite markers in the vicinity of the GUCY2D gene

\begin{tabular}{|c|c|c|c|c|c|c|c|c|}
\hline & \multirow{2}{*}{$\begin{array}{l}\text { Intermarker } \\
\text { distance (cM) }\end{array}$} & \multicolumn{2}{|c|}{ Association with disease } & \multicolumn{5}{|c|}{ Haplotypes or genotypes in families or probands } \\
\hline & & $\lambda$ & $p$ & 2 & 3 & 4 & 5 & 6 \\
\hline D17S796 & 0.13 & 0 & 0.5 & $2(0.25)$ & $5(0.30)$ & 2 & 25 & $1(0.23)$ \\
\hline D17S938 & 0.2 & 0.36 & 0.25 & $7(0.06)$ & $1(0.31)$ & 1 & $1,3(0.03)$ & 7 \\
\hline D17S960 & 0 & 0.57 & 0.03 & $5(0.28)$ & 5 & $3(0.21)$ & 5 & 5 \\
\hline$G U C Y 2 D$ & 0 & - & - & R838C & $\mathrm{R} 838 \mathrm{C}$ & $\mathrm{R} 838 \mathrm{C}$ & $\mathrm{R} 838 \mathrm{C}$ & $\mathrm{R} 838 \mathrm{C}$ \\
\hline D17S1796 & 0 & 0 & 0.5 & $2(0.60)$ & $4(0.30)$ & 2 & $2,5(0.10)$ & 2 \\
\hline D17S1881 & 2.2 & 0.53 & 0.07 & $6(0.17), 8(0.10)$ & $5(0.34)$ & 5 & 5 & 5 \\
\hline D17S1852 & & & ND & 7 & 612 & 910 & 67 & 78 \\
\hline
\end{tabular}

The family numbers are identical to those in table 1 . The numbers in parentheses are the frequencies of each allele on 40 chromosomes obtained from unrelated, "married in" subjects in the families. The statistic $\lambda$ gives an estimate of linkage disequilibrium as determined by the DISLAMB program. ${ }^{9}$ Only D17S 960 shows significant disease association.

a further 40 patients, three additional patients with mutations in this codon have been identified, two with an R838C substitution and one with an $\mathrm{R} 838 \mathrm{H}$ substitution.

The clinical phenotypes in the families with single (R838C or R838H) and double (E837D, R838S) mutations have been reported in detail elsewhere. ${ }^{410} 11$ In summary, the cone-rod dystrophy exhibited by the single mutation patients is less severe than that in the original CORD6 family with the double mutation, with mild variation in disease severity in the R838C families. In all cases, photophobia with decreased visual acuity and loss of colour vision is present from early childhood. However, during the early phases of the disorder when visual acuity is still good, a marked reduction in visual function in bright light is characteristically present. Fundoscopic abnormalities are confined to the central macula with increasing central atrophy with age. Electrophysiological testing showed a marked loss of cone function with only minimal rod involvement in the single mutation families. This contrasts with expression in the CORD6 family where moderate to severe rod involvement is present. ${ }^{11}$ Different mutations in this region of the GUCY2D gene can result therefore in differing severities of cone-rod dystrophy, especially with regard to the involvement of the scotopic system.

Pooling across our two studies, a conservative estimate of the overall frequency of mutations in codon 838 of GUCY2D among autosomal dominant patients with macular, cone, or cone-rod dystrophy is therefore $6.7 \%$, although this rises to $23 \%$ if only the three new mutations found among the 13 cone and conerod dystrophy patients examined in this study are considered. It is important to emphasise that these two frequencies are estimates of the relative contribution that mutations in this codon make to the total frequency of autosomal dominant cone-rod disease in the population and that this conclusion is valid irrespective of the presence or absence of a founder effect for the R838C mutations. Whether such a founder effect is present is unclear from the present data. There is evidence for linkage disequilibrium between the disease allele and one of the flanking markers (D17S960) although, since the disease associated allele is relatively common $(28 \%)$, this renders the test of association less powerful, and the situation is not further resolved by a number of SNPs scattered through the GUCY2D gene, since none was informative in our five families. Where a founder effect has been clearly established, for example for Sorsby's fundus dystrophy, ${ }^{12}$ a highly significant disease associated haplotype covering $3 \mathrm{cM}$ of the chromosomal region surrounding the disease gene was present. In contrast, the disease associated haplotype for the R838C mutations covers $<0.2 \mathrm{cM}$. This indicates that either the $\mathrm{R} 838 \mathrm{C}$ mutations have arisen separately from each other or that a single mutation occurred in a much more distant ancestor than the common mutation for Sorsby's fundus dystrophy, with a consequent wider distribution in the population. Furthermore and again irrespective of the presence or absence of a common ancestor for our R838C families, the occurrence of the R838C mutation in a presumably unrelated Norwegian family, ${ }^{7}$ the $\mathrm{R} 838 \mathrm{H}$ mutations in one of our British families and in a Swiss family, ${ }^{6}$ and the multiple mutations in codon 838 and adjacent codons in the original CORD6 family, ${ }^{4}$ as well as in a French family, ${ }^{5}$ all identify this codon as particularly mutation prone.

Two other dominantly inherited diseases have been associated with mutation prone regions: recurring $C$ to $T$ and $G$ to $A$ transitions were found in adjacent nucleotides within the MYH7 gene in hypertrophic cardiomyopathy ${ }^{13}$ and recurring $G$ to $A$ transitions and $G$ to $C$ transversions were found at the same nucleotide within the FGFR3 gene in achondroplasia. ${ }^{14}$ The recurring DNA transitions at these two loci are situated at $\mathrm{CpG}$ dinucleotides and a study of nucleotide substitution rates ${ }^{15}$ has confirmed the high mutability of CpG sequences. The spontaneous deamination of methylated cytosine, its relatively slow repair in mammalian cells, and the production of an intermediate susceptible to deamination in the enzymatic process by which cytosine itself is methylated, are all mechanisms which make $\mathrm{CpG}$ sequences preferential targets for spontaneous mutation. ${ }^{16}{ }^{17}$ It is perhaps significant therefore that the $\mathrm{C}$ to $\mathrm{T}$ transitions and $\mathrm{C}$ to A transversions found in codons 838 and 
Codons

$836837838 \quad 839840$ CGG GAG CGC ACG GAG

... . . Т .. . . . .

$\ldots \ldots$... A .....

$\ldots$....

$\ldots \ldots$. $\ldots . . \ldots$.

E837D, R838C, T839M

E837D, R838S

$\mathrm{R} 838 \mathrm{C}$

$\mathrm{R} 838 \mathrm{H}$

Figure 2 Nucleotide and amino acid substitutions in exon 13 of GUCY2D associated with autosomal dominant cone-rod dystrophy.

839 of the GUCY2D gene all occur within a $\mathrm{CpG}$ dinucleotide (fig 2). What remains unclear is the mechanism responsible for the generation of multiple mutations in this region of exon 13 of the GUCY2D gene.

Recessive mutations in GUCY2D are a relatively common cause of LCA. However, the widespread distribution of LCA mutations (including missense, frameshift, and splice site changes) throughout the gene ${ }^{18}$ contrasts with the clustering of ADCORD mutations to codons 837, 838, and 839 encoded by exon 13 . To date, no LCA mutations have been localised to exon 13. The causative ADCORD mutations may, however, be even more restricted since the E837D substitution present in patients with double (the original CORD6 family) and triple mutations ${ }^{5}$ would appear by itself to have little effect on enzyme activity in vitro. ${ }^{19}$ In contrast, the changes in codon 838 , $\mathrm{R} 838 \mathrm{H}$, R838C, or R838S, have all been shown to alter the sensitivity of the protein to $\mathrm{Ca}^{2+}$ inhibition via interactions with GCAPs. ${ }^{19-21}$ Substitution at this site may be the critical change therefore in all cases so far reported, in causing ADCORD rather than recessive LCA. The effect of this dominant mutation is a change in function (altered $\mathrm{Ca}^{2+}$ sensitivity) whereas the recessive LCA1 mutations may represent loss of activity. ${ }^{22}$

There have been reports of other retinal dystrophies mapping to regions of chromosome $17 \mathrm{p}$ which overlap with the position of the GUCY2D gene. These include two dominant cone dystrophies and dominant central areolar choroidal dystrophy, diseases which exhibit degeneration primarily of the cone-rich macular region only. ${ }^{23-25}$ As yet, there have been no reports of GUCY2D mutations in these disorders, despite screening this gene in patients with central areolar choroidal dystrophy. ${ }^{26}$

We thank the patients for their cooperation in this study. This work was supported by the Wellcome Trust (grant numbers 041905 and 053405 ) and the Medical Research Council (grant number G9301094). We would also like to thank the Wellcome Trust for a Major Equipment Grant for the sequencing facility (grant number 039283).

1 Lagnado L, Baylor D. Signal flow in visual transduction. Neuron 1992;8:995-1002.

2 Perrault I, Rozet JM, Calvas P, Gerber S, Camuzat A, Dollfus $\mathrm{H}$, Chatelin S, Souied E, Ghazi I, Leowski C, Bonnemaison M, Le Paslier D, Frezal J, Dufier JL, Pittler Bonnemaison M, Le Paslier D, Frezal J, Dufier JL, Pittler
S, Munnich A, Kaplan J. Retinal-specific guanylate cyclase S, Munnich A, Kaplan J. Retinal-specific guanylate cyclase gene mutations

3 Perrault I, Rozet JM, Munnich A, Kaplan J. Des mutations retrouvées pour la première fois dans une guanylyl cyclase (retGC) responsables d'une cécité néonatale: l'amaurose congénitale de Leber. M/S Med Sci 1997;13:581-3. Kelsell RE, Gregory-Evans K, Payne AM, Perrault I,
Kaplan J, Yang RB, Garbers DL, Bird AC, Moore AT, Kaplan J, Yang RB, Garbers DL, Bird AC, Moore AT, Hunt DM. Mutations in the retinal guanylate cyclase
(RETGC-1) gene in dominant cone-rod dystrophy. Hum (RETGC-1) gene in dominan

5 Perrault I, Rozet JM, Gerber S, Kelsell RE, Souied E, Cabot A, Hunt DM, Munnich A, Kaplan J. A retGC-1 mutation in autosomal dominant cone-rod dystrophy. Am $\mathcal{F}$ Hum Genet 1998;63:651-4.

6 Weigell-Weber M, Fokstuen S, Torok B, Niemeyer G, Schinzel A, Hergersberg M. Codons 837 and 838 in the retinal guanylate cyclase gene on chromosome $17 \mathrm{p}$ : hot spots for mutations in autosomal dominant cone-rod dystrophy? Arch Ophthalmol 2000;118:300.

7 Van Ghelue M, Eriksen HL, Ponjavic V, Fagerheim T, Andréasson S, Forsman-Semb K, Sandgren O, Holmgren $\mathrm{G}$, Tranebjærg L. Autosomal dominant cone-rod dystrophy due to a missense mutation (R838C) in the guanylate cyclase $2 \mathrm{D}$ gene $(G U C Y 2 D)$ with preserved rod function in one branch of the family. Ophthal Genet (in press).

8 Keen J, Lester D, Inglehearn C, Curtis A, Bhattacharya SS. Rapid detection of single base mismatches as heteroduRapid detection of single base mismatches as he
plexes on HydroLink gels. Trends Genet 1993;7:5.

plexes on HydroLink gels. Trends Genet 1993;7:5.
9 Terwilliger JD. A powerful likelihood method for the analyTerwilliger JD. A powerful likelihood method for the analy-
sis of linkage disequilibrium between trait loci and one or more polymorphic marker loci. Am f Hum Genet 1995;56: 777-87.

10 Downes SM, Payne AM, Kelsell RE, Fitzke FW, Holder GE, Hunt DM, Moore AT, Bird AC. Autosomal dominant cone-rod dystrophy with mutations in the retinal guanylate cyclase GUCY2D gene encoding RetGC1. Arch Ophthalmol (in press)

11 Gregory-Evans K, Kelsell RE, Gregory-Evans CY, Downes , Fitzke FW, Holder GE, Simunovic M, Mollon JD, Tayor R, Hunt DM, Bird AC, Moore AT. Autosomal dominant cone-rod retinal dystrophy (CORD6) from heterozygous mutation of GUCY2D, which encodes retinal guanylate cyclase. Ophthalmology 2000;107:55-61.

2 Wijesuriya SD, Evans K, Jay MR, Davison C, Weber BHF, Bird AC, Bhattacharya SS. Sorsby's fundus dystrophy in the British Isles: demonstration of a striking founder effect by microsatellite-generated haplotypes. Genome Res 1996; 6:92-101

13 Moolman JC, Brink PA, Corfield VA. Identification of a new missense mutation at Arg403, a CpG mutation hotspot, in exon 13 of the $\beta$-myosin heavy chain gene in hypertrophic cardiomyopathy. Hum Mol Genet 1993;2:1731-2.

14 Bellus GA, Hefferton GW, Ortiz de Luna, RI, Hecht JT, Horton WA, Machado M, Kaitila I, McIntosh I, Francomano CA. Achondroplasia is defined by recurrent G380R mutations of FGFR3. Am f Hum Genet 1995;56: 368-73

15 Krawcza M, Ball EV, Cooper DN. Neighbouring-nucleotide effects on the rates of germ-line single base pair substitution in human genes. Am f Hum Genet 1998;63: 474-88.

16 Lindahl $\mathrm{T}$. Instability and decay of the primary structure of DNA. Nature 1993;362:709-15.

17 Cooper DN, Youssoufian H. The CpG dinucleotide and human genetic disease. Hum Genet 1988;78:151-5.

18 Perrault I, Rozet JM, Gerber S, Ghazi I, Leowski C, Ducroq D, Souied E, Dufier JL, Munnich A, Kaplan J. Leber congenital amaurosis. Mol Genet Metab 1999;68:200-8.

19 Tucker CL, Woodcock SC, Kelsell RE, Ramamurthy V, Hunt DM, Hurley JB. Biochemical analysis of a dimerization domain mutation in RetGC-1 associated with dominant cone-rod dystrophy. Proc Natl Acad Sci USA 1999;96:9039-44

20 Ramamurthy V, Wilkie SE, Warren MJ, Hunt DM, Hurley JB. Role of dimerization domain in activation of human retinal guanylyl cyclase-1 (RetGC-1) and dominant cone-rod dystrophy (CORD). Invest Ophthalmol Vis Sci 2000;41:S533.

21 Wilkie SE, Newbold RJ, Deery E, Walker CE, Stinton I, Ramamurthy V, Hurley JB, Bhattacharya SS, Warren MJ, Ramamurthy V, Hurley JB, Bhattacharya SS, Warren MJ, tions at codon 838 in retinal guanylate cyclase correlates with disease severity in patients with autosomal dominant with disease severity in patients with autosomal domin
cone-rod dystrophy. Hum Mol Genet 2000;9:3065-73.

22 Duda T, Venkataraman V, Goraczniak R, Lange C, Koch K, Sharma RK. Functional consequences of a rod outer segment membrane guanylate cyclase (ROS-GC1) gene mutation linked with Leber's congenital amaurosis. Biochemistry 1999;38:509-15.

23 Balciuniene J, Johansson K, Sandgren O, Wachtmeister L, Holmgren G, Forsman K. A gene for autosomal dominant progressive cone dystrophy (CORD5) maps to chromosome 17p12-p13. Genomics. 1995;30:281-6.

24 Small KW, Syrquin M, Mullen L, Gehrs K. Mapping of autosomal dominant cone degeneration to chromosome 17p. Am f Ophthalmol 1996;121:13-18.

25 Lotery AJ, Ennis KT, Silvestri G, Nicholl S, McGibbon D, Collins AD, Hughes AE. Localisation of a gene for central areolar choroidal dystrophy to chromosome $17 \mathrm{p}$. Hum Mol Genet 1996:5:705-8.

26 Lotery AJ, Hughes AE, Silvestri G, Tombran-Tink J, Archer DB. Characterisation of candidate genes for central areolar choroidal dystrophy on chromosome 17p. Invest Ophthalmol Vis Sci 1997;38:3722. 


\title{
A G339R mutation in the CTNS gene is a common cause of nephropathic cystinosis in the south western Ontario Amish Mennonite population
}

\author{
C Anthony Rupar, Douglas Matsell, Susan Surry, Victoria Siu
}

f Med Genet

2001;38:615-616

Department of

Biochemistry,

University of Western

Ontario, London, ON,

Canada

C A Rupar

Department of

Paediatrics, University

of Western Ontario,

London, ON, Canada

C A Rupar

D Matsell

S Surry

V Siu

Child Health Research Institute, University of Western Ontario, London, ON, Canada C A Rupar

Child and Parent Resource Institute, University of Western Ontario, London, ON, Canada

C A Rupar

Correspondence to: $\mathrm{Dr}$ Rupar, Biochemical Genetics Laboratory, CPRI, 600 Sanatorium Road, London, Ontario, Canada N6H 3W7, trupar@julian.uwo.ca

Table 1 Primers for amplifying CTNS exons and testing for the $65 \mathrm{~kb}$ deletion

\begin{tabular}{|c|c|c|}
\hline Exon & Direction & Sequence \\
\hline \multirow[t]{2}{*}{3} & Forward & 5'- CAG ATT GTC TAC AGG GAG CT -3' \\
\hline & Reverse & 5'- CTT GGC AAC AAA CAG ATC AG -3' \\
\hline \multirow[t]{2}{*}{4} & Forward & 5'- CTG ACC CAG TGC CTC ATG TC -3' \\
\hline & Reverse & 5'- GAG CTG AGC ACA GCG CCA -3' \\
\hline \multirow[t]{2}{*}{5} & Forward & 5'- TCC AGC TTC TCA GCA GTA AT -3' \\
\hline & Reverse & 5'- ACC TAG CAT TTC CCT ACC C -3' \\
\hline \multirow[t]{2}{*}{6} & Forward & 5'- GCG GGG TCC TCG GTA ACT G -3' \\
\hline & Reverse & 5'- CAG CAC GGC CCC CTT CT -3' \\
\hline \multirow[t]{2}{*}{7} & Forward & 5'- AGT CTC CTT CAG AAG CCC AG -3' \\
\hline & Reverse & 5'- GGC AGA CAG AAG GGT AGA GG -3' \\
\hline \multirow[t]{2}{*}{8} & Forward & 5'- CCC TGC CCT GTC TTG TCC -3' \\
\hline & Reverse & 5'- CAG AGA TGT AGG GCA GGC AA -3' \\
\hline \multirow[t]{2}{*}{9} & Forward & 5'- CAT CTC TGC CCA CAT GGC GT -3' \\
\hline & Reverse & 5'- GCT CTG CCG TGT CTT CTG TC -3' \\
\hline \multirow[t]{2}{*}{10} & Forward & 5'- GGC CTC TGT GTG GGT CC -3' \\
\hline & Reverse & 5'- GGC CAT GTA GCT CTC ACC TC -3' \\
\hline \multirow[t]{2}{*}{11} & Forward & 5'- GCC CTC CGT CTG TCT GTC CG -3' \\
\hline & Reverse & 5'- GCC CGA TGC CCC AGC -3' \\
\hline \multirow[t]{2}{*}{12} & Forward & 5'- TCG GAG ACC CAA CCA AGT TT -3' \\
\hline & Reverse & 5'- TGG CCC CAG GAG CAG AGT GG -3' \\
\hline \multirow[t]{2}{*}{$\mathrm{LDM}-1^{\star}$} & Forward & 5'- CCG GAG TCT ACA GGG CAC AG -3' \\
\hline & Reverse & 5'- GGC CAT GTA GCT CTC ACC TC -3' \\
\hline \multirow[t]{2}{*}{ D17S829* } & Forward & 5'- CTA GGG GAG CTG GTT AGC AT -3' \\
\hline & Reverse & 5'- TGT AAG ACT GAG GCT GGA GC -3' \\
\hline
\end{tabular}

«Sequences from Anikster et al. $^{4}$
EDITOR-Nephropathic cystinosis (MIM $219800)$ is a rare autosomal recessively inherited lysosomal storage disorder with a newborn incidence of about 1 in 100 000-200 000 in the general population (OMIM). Cystine accumulates in lysosomes because of dysfunctional cystinosin mediated transport of cystine out of lysosomes. The accumulation of cystine results in damage to several organs with renal damage being the most pronounced in the first decade of life. Patients with cystinosis experience both tubular dysfunction (renal Fanconi syndrome) and glomerular deterioration. Renal Fanconi syndrome usually occurs within the first year of life with glomerular deterioration progressing throughout the first decade of life resulting in end stage renal failure. ${ }^{1}$

The CTNS gene was mapped to chromosome $17 \mathrm{p} 13$ and subsequently isolated and characterised to have 12 exons spanning $23 \mathrm{~kb}$ of genomic DNA. ${ }^{2} 3$ The most common mutation that causes cystinosis is a large deletion that encompasses exons $1-10 .{ }^{4}$ Originally, this deletion was described as $65 \mathrm{~kb}$ long but the size has been recently refined to 57257 bases. $^{5}$ Forty four percent of 108 American based patients with nephropathic cystinosis were homozygous for this deletion. ${ }^{6}$

At least seven children in the Old Order Amish population in south western Ontario, Canada have been diagnosed with nephropathic cystinosis. This population is a culturally isolated population founded in 1824 by emigrants from Bavaria and Alsace-Lorraine.

.

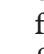

Further immigration occurred from the same regions and more recently from the United States.

Within this Amish community, we have recently diagnosed four children with cystinosis, two sibs in two families not known to be related. In each family the parents are consanguineous. The proband presented at 14 months of age with protracted vomiting and dehydration, polyuria, polydipsia, and failure to thrive. On initial investigations he had a metabolic acidosis, hypophosphataemia, hypokalaemia, and glucosuria. Slit lamp examination of his eyes showed corneal crystals. Urine amino acid analysis indicated a generalised amino aciduria. At presentation he had no evidence of renal insufficiency. A leucocyte cystine level done before the initiation of treatment was $1.99 \mathrm{nmol} \mathrm{1/2}$ cystine/mg protein. Patients with untreated cystinosis usually have greater than $2.0 \mathrm{nmol} 1 / 2$ cystine/mg protein (Dr J A Schneider, San Diego). His younger sister was diagnosed at 8 months when she presented with a similar clinical history and a leucocyte cystine of $1.19 \mathrm{nmol} 1 / 2$ cystine $/ \mathrm{mg}$ protein before the initiation of treatment. Leucocyte cystine concentrations were measured at the Cystine Determination Laboratory, UCSD, La Jolla, CA using the cystine binding protein assay.

DNA was isolated from blood specimens that were obtained after receiving consent from the parents. Mutations were identified in the CTNS gene by PCR amplification and direct sequencing (ABI PRISM Model 377 sequencer) of exons 3-10 and PCR amplification for detection of the 57257 base deletion using

A mutation, $1354 \mathrm{G} \rightarrow \mathrm{A}$, was identified in exon 12. This mutation results in the loss of an AvaI restriction site. The proband was homozygous for the $1354 \mathrm{G} \rightarrow \mathrm{A}$ mutation as shown in fig 1 and no other mutations were identified. This mutation results in a glycine 339 to arginine amino acid change in a transmembrane region of cystinosin. All four cystinosis patients from the two families were homozygous for this mutation and an unaffected sister was heterozygous.

The G339R mutation has been previously identified in one allele in a compound heterozygous patient of Italian ancestry. ${ }^{6}$ Further evidence that this mutation is pathogenetic is that glycine 339 is an amino acid which is conserved between $C$ elegans and humans in cystinosin. ${ }^{6}$ In our patients, homozygosity for the G339R mutation seems to be associated 


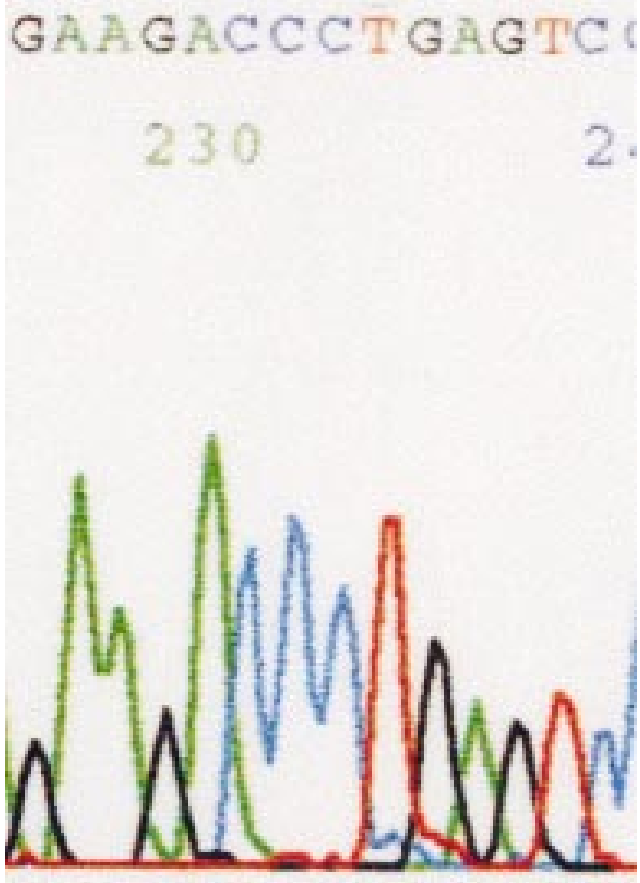

Figure 1 Part of the DNA sequence of exon 12 showing that the patient is homozygous for the $1354 \mathrm{G} \rightarrow A$ mutation. The sequence is in the reverse direction with the normal sequence across this region being GAAGACCCCGAGTC.

with a relatively low concentration of leucocyte cystine.

Germany is likely to be the country of origin for the common 57257 base deletion in the CTNS gene. ${ }^{5}$ The Amish Mennonite population originated in Germany but appears to have the G339R mutation exclusively rather than the 57257 base deletion. This may reflect a founder effect but there are no data to indicate from whom or when the founder allele originated. Cystinosis does not appear to be present in the Amish population of Pennsylvania, suggesting that the mutation may have originated in a founder who emigrated to south western Ontario directly from Europe. A study of other populations that are related to the population from which this Amish community is derived would be helpful in this regard.

There are no data on the incidence of cystinosis or the prevalence of the G339R allele in the south western Ontario Amish Mennonite community. Our awareness of seven cases in the past 10 years suggests an incidence far greater than that of the general population.

There is evidence that the earlier that cysteamine therapy is started the less cystine accumulates in tissues. Markello et al showed that the treatment of children with cystinosis with cysteamine before the onset of end stage renal disease resulted in a delay in the need for renal replacement therapy when compared to children not treated or not compliant with therapy. Early therapy has also been shown to prevent hypothyroidism ${ }^{8}$ and the accumulation of cystine in muscle. ${ }^{9}$

If this Amish Mennonite community wishes, the determination of the frequency of the G339R allele within the population using the AvaI restriction site would enable the prediction of the population incidence of cystinosis. This incidence may be high enough to justify targeted newborn screening and early institution of management.

Electronic database information: Online Mendelian Inheritance in Man (OMIM), http://www.ncbi.nlm.nih.gov/Omim (for cystinosis (MIM 219800)).

Technical assistance was provided by Roger Dewar and Sajid Shaikh.

1 Gahl WA, Schneider JA, Aula P. Lysosomal transport disorders: cystinosis and sialic acid storage disorders. In: Scriver CR, Beaudet AL, Sly WS, Valle D, eds. The metabolic and molecular bases of inherited diseases. 7th ed. New York: molecular bases of inherited disec

2 Cystinosis Collaborative Research Group. Linkage of the gene for cystinosis to markers on the short arm of chromoome 17. Nat Genet 1995;10:246-8.

3 Town M, Jean G, Cherqui S, Attard M, Forestier L, Whitmore SA, Callen DF, Gribouval O, Broyer M, Bates GP, van't Hoff W, Antignac C. A novel gene encoding an integral membrane protein is mutated in nephropathic cystinosis. Nat Genet 1998;18:319-24.

4 Anikster Y, Lucero C, Touchman J, Huizing M, McDowell G, Shotelersuk V, Green ED, Gahl WA. Identification and detection of the common $65-\mathrm{kb}$ deletion breakpoint in the nephropathic cystinosis gene (CTNS). Mol Genet Metab 1998;66:111-16.

5 Touchman JW, McDowell G, Shotelersuk V, Bouffard GG, Beckstrom-Sternberg SM, Anikster Y, Dietrich NL, Maduro Gahl WA, Green ED. The genomic region encompassing the nephropathic cystinosis gene (CTNS): Compassing the nephropathic cystinosis gene (CTNS): Com-
plete sequencing of a 200-kb segment and discovery of a novel gene within the common cystinosis-causing deletion. Genome Res 2000;10:165-73.

6 Shotelersuk V, Larson D, Anikster Y, McDowell G, Lemons R, Bernardini I, Guo J, Thoene J, Gahl WA. CTNS mutations in an American-based population of cystinosis patients. Am f Hum Genet 1998;63:1352-62.

7 Markello TC, Bernardini IM, Gahl WA. Improved renal function in children with cystinosis treated with cysteamine. N Engl f Med 1993;328:1157-62.

8 Kimonis VE, Troendle J, Rose SR, Yang ML, Markello TC, Gahl WA. Effects of early cysteamine therapy on thyroid function and growth in nephropathic cystinosis. F Clin Endocrinol Metab 1995;80:3257-61.

9 Gahl WA, Charnas L, Markello TC, Bernardini I, Ishak KG, Dalakas MC. Parenchymal organ depletion with longterm cysteamine therapy. Biochem Med Metab Biol 1992;48: 275-85. 


\title{
De novo terminal deletion of chromosome $15 \mathrm{q} 26.1$ characterised by comparative genomic hybridisation and FISH with locus specific probes
}

\author{
Holger Tönnies, Ilka Schulze, Hans-Christian Hennies, Luitgard Margarete Neumann, \\ Rolf Keitzer, Heidemarie Neitzel
}

EDITOR-Reports of patients with terminal de novo deletions of chromosome $15 \mathrm{q} 26$ are rare. Excluding cases of ring chromosome 15 formation with different sized deleted chromosomal segments, only seven cases with solely distal deletions of $15 \mathrm{q}$ have been published. ${ }^{1-7}$ All other cases resulted from unbalanced reciprocal translocations involving different chromosomes and are therefore not comparable with de novo terminal deletions as described in our case.

With two exceptions, all de novo cases had interstitial deletions between chromosomal bands 15q21-q25. Only the patients described by Roback et $a \bar{l}$ and Siebler et $a l^{6}$ had terminal deletions of 15q26.1. The deletions in these patients were not investigated by FISH, but molecular genetic techniques showed the loss of one copy of the insulin-like growth factor 1 receptor gene. IGF1R is a tyrosine kinase containing transmembrane protein that plays an important role in cell growth control. It has been assumed that monozygosity for this gene, which maps to distal 15q26, will directly disturb this pathway and inhibit normal growth of patients. ${ }^{8}$

Today, in addition to classical cytogenetic banding methods, FISH techniques including comparative genomic hybridisation (CGH) can be used to provide a powerful tool to characterise chromosomal aberrations. In this study, we present the molecular cytogenetic findings and the detailed clinical phenotype of a girl with deletion 15q26.1 and compare these with other published cases. Our patient described here is, to the best of our knowledge, the second patient with a de novo terminal deletion at 15q26.1 and the first one well characterised by molecular cytogenetic techniques.

Department of General Paediatrics, Charité, Campus Virchow-Klinikum, Humboldt-University, Augustenburger Platz 1, D-13353, Berlin, Germany

I Schulze

R Keitzer

Department of Molecular Genetics and Gene Mapping Centre,

Max-Delbrueck Centre

for Molecular

Medicine, Berlin,

Germany

H-C Hennies

Correspondence to: Dr Tönnies,

Toennies@charite.de
Furthermore, there was a blood pressure difference between the upper and the lower
The female infant was the first child of healthy, unrelated parents. An ultrasound examination at 15 weeks of gestation showed intrauterine growth retardation. At 39 weeks of gestation a caesarean section became necessary because of fetal heart rate deceleration. The Apgar scores were 6,8 , and 10 at one, five, and 10 minutes, respectively. Her birth weight was $1980 \mathrm{~g}(<3 \mathrm{rd}$ centile) with a length of $42 \mathrm{~cm}$ ( $<3 \mathrm{rd}$ centile) and a head circumference of $30 \mathrm{~cm}(<3 \mathrm{rd}$ centile). The first chromosome analysis after birth in an outside laboratory showed a normal female karyotype. The girl had minor anomalies including micrognathia, low set ears, a broad nasal bridge, and a short neck (fig 1). extremities. Cardiac examination including cardiac catheterisation exhibited a complex heart defect with ventricular septal defect (VSD), atrial septal defect (ASD), preductal coarctation of the aorta, patent ductus arteriosus, and arteria lusoria. This complex congenital heart disease was corrected by several surgical interventions up to the age of 3 months. Laboratory findings including IGF1 and a screening for congenital infection were normal except for a transient hypothyroidism owing to maternal hypothyroidism. Renal ultrasonography showed a slight ectasia of the left renal pelvis from the age of 7 months. Neurological examination showed developmental delay but no other pathological findings. At the age of 15 months the infant could roll over but could not sit without support. Furthermore, she had severe feeding problems with gastrooesophageal reflux and vomiting. Because of increasing vomiting and a lack of weight gain, a gastrostomy feeding tube had to be inserted. For the whole period of time the girl continued to have poor development and severe failure to thrive. At the age of 16 months her weight was $5300 \mathrm{~g}$ ( $<<3 \mathrm{rd}$ centile), length was $62 \mathrm{~cm}$ $(<<3$ rd centile), and head circumference was $39 \mathrm{~cm}(<<3$ rd centile).

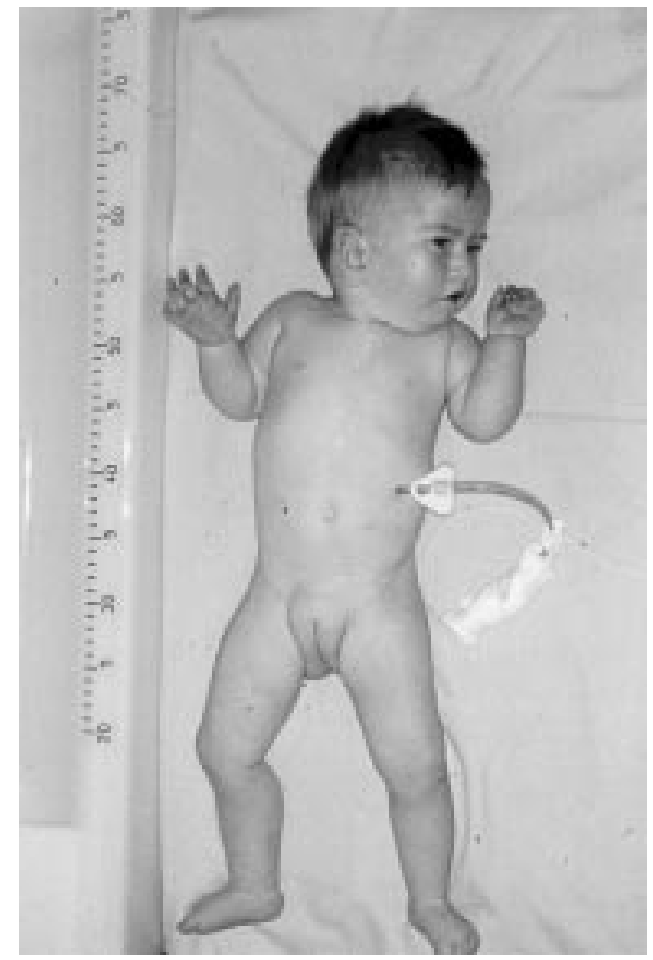

Figure 1 The patient at the age of 19 months. 
Material and methods

Blood samples from the patient and her parents were drawn after informed consent. High resolution chromosome analyses from peripheral blood lymphocytes of the patient and both parents were performed using standard techniques. Preparations were GTG banded and karyotyped using the Ikaros system (Metasystems, Altlussheim, Germany).

Whole chromosome painting (WCP) was initiated using the probe for chromosome 15 (VYSIS). YAC clones for chromosome 15 were selected from the CEPH mega-YAC library and obtained through the Positional Cloning Centre at the Max-Planck Institute of Molecular Genetics (Berlin, Germany). YAC DNA was amplified and labelled by degenerate oligonucleotide primed polymerase chain reaction (DOP-PCR) with minor modifications. ${ }^{9}$ YAC-FISH was performed according to standard protocols. Hybridisation of commercial probes for the subtelomeric region of chromosome 15q (TelVysion 15q, VYSIS) and the all human telomeres probe (ONCOR) were according to the manufacturers' instructions. All probes used were directly labelled with fluorochromes.

Genomic DNA of the patient was investigated by comparative genomic hybridisation using normal male reference DNA as a control. DNA was isolated using standard methods. Briefly, genomic DNA samples were differently labelled by nick translation with SpectrumGreen ${ }^{\circledR}$-dUTP (VYSIS, test DNA) and SpectrumOrange ${ }^{\circledR}$-dUTP (VYSIS, reference DNA). For each hybridisation, $200 \mathrm{ng}$ of labelled test DNA, $200 \mathrm{ng}$ reference DNA, and $12.5 \mu \mathrm{g}$ Cot-1 DNA were coprecipitated, resuspended in $14 \mu \mathrm{l}$ hybridisation mix containing $50 \%$ formamide, $2 \times$ SSC, and $10 \%$ dextran sulphate, denatured at $70^{\circ} \mathrm{C}$ for five minutes, and hybridised to denatured normal male metaphase spreads. Slides were incubated at $37^{\circ} \mathrm{C}$ in a moist chamber for two days. Posthybridisation washes were performed as described previously..$^{10}$ Images of the hybridised metaphases were evaluated using an epifluorescence microscope (Axiophot, ZEISS, Germany) fitted with different single band pass filter sets for DAPI, SpectrumGreen ${ }^{\circledR}$, and SpectrumOrange ${ }^{\circledR}$ fluorescence. The microscope is equipped with a cooled CCD camera (Hamamatsu) for image acquisition. Image analysis and karyotyping (CGH) was performed using the ISIS analysis system (Metasystems, Germany). Diagnostic thresholds used for the identification of chromosomal under-representations (deletions) and overrepresentations (duplications) were 0.85 and $1.17 .^{11}$

Microsatellite markers on chromosome 15q were analysed in the patient and her parents. Marker loci were chosen from the Généthon final linkage map and from the Marshfield comprehensive human genetic maps. ${ }^{12}{ }^{13}$ Markers were amplified by PCR in a final reaction volume of $10 \mu \mathrm{l}$ containing $10 \mathrm{mmol} / 1$ Tris, 1.5 $\mathrm{mmol} / 1 \mathrm{MgCl}_{2}, 100 \mu \mathrm{mol} / 1$ each dNTP, $0.4 \mathrm{U}$ polymerase (Applied Biosystems), $7 \mathrm{pmol}$ of each primer, and $20 \mathrm{ng}$ of genomic DNA. One of the primers was end labelled with fluorescent dye. DNA amplification was carried out in an MJ Research PTC-225 thermal cycler. Reactions were electrophoresed on an ABI PRISM 377 automatic DNA sequencer (Applied Biosystems). Data were analysed using the computer programs Genescan v3.0 and Genotyper v2.5 (Applied Biosystems).

\section{Results}

Cytogenetic studies from the peripheral blood lymphocytes of the patient at the age of 9 months showed a female karyotype with a small deletion in the long arm of chromosome 15 at the 500-600 band level (fig 2). ${ }^{14}$ After conventional cytogenetics, the extent of the deletion was assumed to be from band 15q25 26 to the distal end of the chromosome, but it was impossible to decide whether the deletion was interstitial or terminal. Maternal and paternal karyotypes were normal at the same resolution level.

For further characterisation of the deletion, CGH was performed using total DNA from the patient as a probe. The averaged ratio profile analysis clearly indicated a terminal deletion (dim) of the chromosomal region 15q26 (fig 2). No other chromosome showed any ratio profile imbalance.

This result was in agreement with the FISH analysis using a chromosome 15 specific whole chromosome paint (VYSIS) showing homogeneous painting of the whole deleted chromosome 15 without any hint of a translocation of the missing chromosome 15 material to any other chromosome (data not shown).

To define the proximal and distal boundaries of the deletion, FISH with different YAC clones was performed. Two of five YAC clones localised in chromosome band 15q25 (81-84 $\mathrm{cM}$, table 1) showed signals on both chromosomes 15 on metaphase preparations of the patient (fig 3). Three YAC clones, 963d03, $895 \mathrm{~h} 10$, and $882 \mathrm{~h} 08$, localised distal to chromosome band 15q25 (98-110 cM), were missing from the patient's deleted chromosome 15 (fig 3).

To delineate this chromosomal abnormality further, FISH with a probe hybridising to unique telomeric DNA sequences of chromosome 15q (TelVysion 15q, VYSIS) was performed. The investigation showed that a signal of this $100 \mathrm{~kb}$ sized probe for chromosome $15 \mathrm{q}$ is missing on the deleted chromosome 15 (fig 3). In contrast, FISH with an all telomeric probe (ONCOR) detecting the highly repeated (TTAGGG)n sequences located at the telomeres of all human chromosomes showed telomeric signals on both the normal and the deleted chromosome 15 as well as on all other chromosomes (fig 3). Thus the patient's karyotype can be summarised as: 46, XX, del(15)(q26.1).ish $\quad \operatorname{del}(15)(\mathrm{D} 15 \mathrm{~S} 130-$, D15S207/D15S157-, D15S120/D15S203D15S936-).

In order to complement the FISH data and to substantiate the loss of the IGF1R gene locus, a microsatellite analysis was performed. Twelve polymorphic markers from chromosome 15q were analysed (table 1). All the 


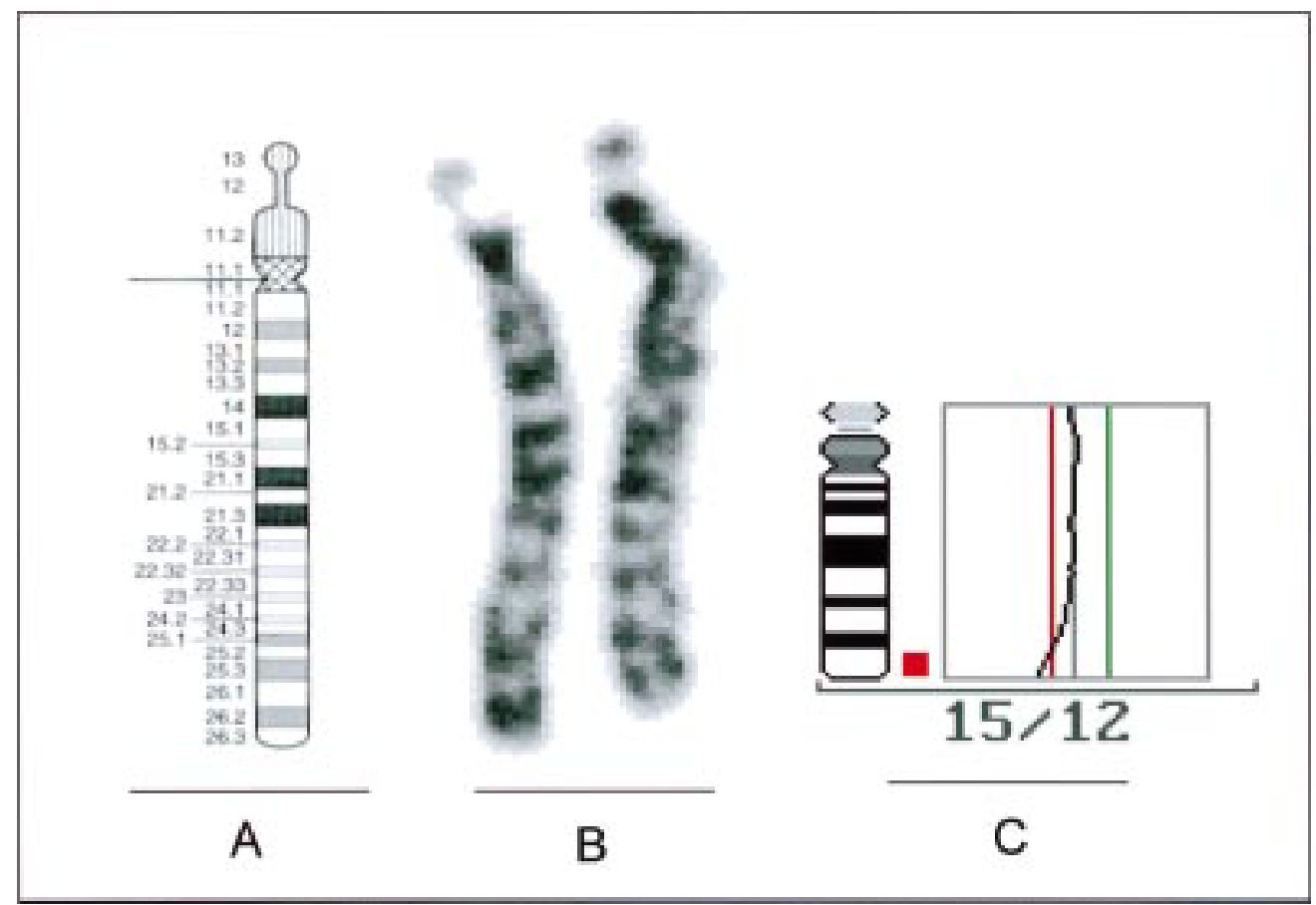

Figure 2 Ideogram ${ }^{14}$ of the human chromosome $15(A)$ and the patient's chromosomes 15 (B) after GTG banding. The normal chromosome 15 is to the left of the deleted chromosome 15. (C) Averaged CGH ratio profile of 12 measured chromosomes 15 of the patient.

markers but those at D15S152, D15S1014, and D15S120 were informative for the family. Segregation of two different alleles clearly showed that the patient carries two copies of chromosome $15 \mathrm{q}$ proximal to D15S652 (table 1). Hence, the proximal boundary of the deletion is in the $10 \mathrm{cM}$ interval between D15S652 and D15S130, so the deletion lies between D15S652 and the telomere. This finding is in accordance with the proximal boundary of the deletion defined by YAC hybridisation (table 1). Unfortunately, there is no true telomeric marker available on chromosome 15q, and the distance between the most distal marker at D15S642 and the telomere remains unclear. Additionally, it could be determined that the

Table 1 Detection of chromosome $15 q$ loci by FISH and microsatellite analysis

\begin{tabular}{|c|c|c|c|c|c|}
\hline STS & $c M^{\star}$ & Probe (YAC clone) & Methodt & $\begin{array}{l}\text { Normal } \\
\text { chromosome } 15\end{array}$ & $\begin{array}{l}\text { Derivative } \\
\text { chromosome } 15\end{array}$ \\
\hline D15S153 & 62.1 & - & MS & + & + \\
\hline D15S114 & 72.3 & - & MS & + & + \\
\hline D15S152 & 78.6 & - & MS & NI & NI \\
\hline D15S199 & 81.9 & $913 \mathrm{e} 02$ & FISH & + & + \\
\hline D15S979 & 82.4 & - & MS & + & + \\
\hline D15S1045 & 84.7 & $859 \mathrm{c} 06$ & FISH & + & + \\
\hline D15S127 & 84.8 & - & MS & + & + \\
\hline D15S963 & 85.8 & - & MS & + & + \\
\hline D15S652 & 88.0 & - & MS & + & + \\
\hline D15S130 & 98.0 & $963 \mathrm{~d} 03$ & FISH & + & - \\
\hline D15S130 & 98.0 & - & MS & + & - \\
\hline D15S207/ & 100.8 & $895 \mathrm{~h} 10$ & FISH & + & - \\
\hline D15S157 & 103.5 & & & & \\
\hline D15S1014 & 103.5 & - & MS & NI & NI \\
\hline D15S120/ & 109.6 & $882 \mathrm{~h} 08$ & FISH & + & - \\
\hline D15S203 & 109.6 & & & & \\
\hline D $15 S 120$ & 109.6 & - & MS & NI & $\mathrm{NI}$ \\
\hline D15S966 & 110.2 & - & MS & + & - \\
\hline D15S642 & (119.8) & - & MS & + & - \\
\hline D15S936 & $?$ & TelVysion 15q & FISH & + & - \\
\hline Telomere & ? & All telomeric probe & FISH & + & + \\
\hline
\end{tabular}

${ }^{\star}$ Genetic localisation according to Dib et al. ${ }^{12}$ The distance between D15S966 and D15S642 was obtained from Broman et al. ${ }^{13}$

†Loci were studied either by FISH with YAC clones or by analysis of microsatellites (MS).

+ , allele detected; -, allele missing; NI, not informative. aberrant chromosome 15 was of paternal origin. The IGF1R gene is located close to D15S120 as shown by radiation hybrid mapping between D15S107 and D15S87..$^{15}$ These two markers are within the deleted region of our patient who therefore exhibits monozygosity for the IGF1R gene.

\section{Discussion}

Terminal deletions of chromosome $15 \mathrm{q}$ are rare events or are seldom diagnosed. Only a few cases of de novo distal deletions of chromosome $15 \mathrm{q}$ without ring formation have been described and the vast majority have been characterised by standard banding only yielding breakpoints in the range from $15 \mathrm{q} 24$ to 15q26. We describe here a new case of terminal deletion 15q26. Even with high resolution chromosome analysis, it was difficult to determine the exact size of the deletion. Therefore, we used different molecular cytogenetic approaches like CGH and FISH with YAC clones and commercially available telomeric probes to refine the deleted chromosome region to chromosome band $15 \mathrm{q} 26$. However, even with the molecular cytogenetic investigation, it was impossible to differentiate between an interstitial versus terminal deletion. The result of the FISH analysis with the YAC from the subtelomere of 15q (Telvision, D15S936) clearly showed a deletion on the aberrant 15 while a signal could be detected on both chromosomes 15 with the all telomeric repetitive probe (TTAGGG)n.

Therefore, it cannot be shown whether the telomeric sequence (TTAGGG)n at the distal end of the deleted chromosome 15 was from the paternal chromosome, or whether it derived from another chromosome by translocation. 

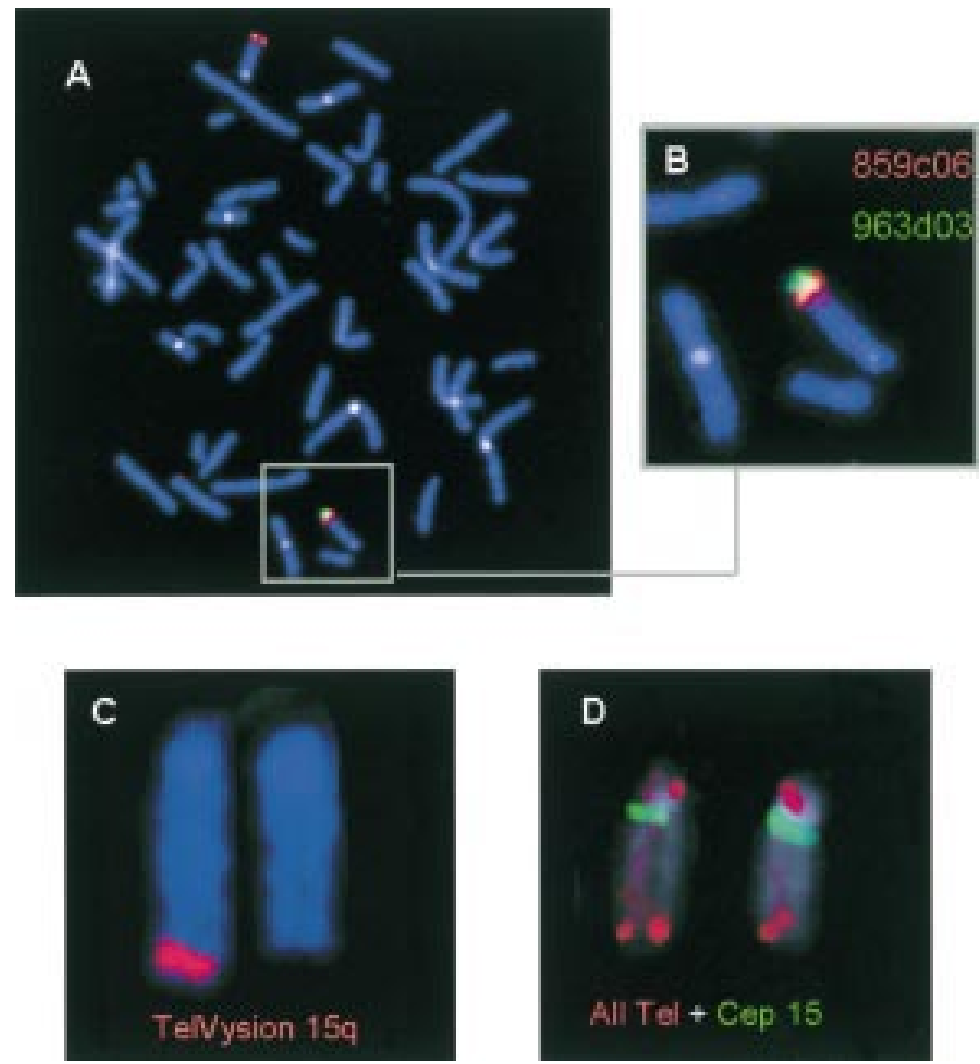

Figure 3 FISH images of YAC clones and commercially available probes hybridised to the patient's chromosomes. (A) Fluorescence signals after hybridisation of the YAC clones $859 \mathrm{c} 06$ and 963d03. There is no signal for the latter clone in the patient's deleted chromosome 15. Both signals are seen in the linear orientation in the normal chromosome 15 (see B, magnification). (C) The subtelomeric TelVysion probe for chromosome 15q is also missing in the deleted chromosome 15. (D) A normal signal is seen for the all human telomeres probe detecting the highly repeated DNA (TTAGGG)n sequences located at the telomeres of all human chromosomes.

New studies on terminal deletions also suggest that de novo telomere addition could occur either mediated by telomerase or by recombination based mechanisms. ${ }^{17}$ In addition to the characterisation of the size of the deletion by in situ hybridisation, the deleted interval was determined by the analysis of microsatellites. These studies showed that the de novo deleted chromosome 15 was of paternal origin. This result is consistent with the paternal origin in the case described by Roback et al. ${ }^{5}$

Most patients with deletions of distal $15 \mathrm{q}$ have intrauterine growth retardation (IUGR), microcephaly, abnormal face and ears, micrognathia, a high arched palate, renal abnormalities, lung hypoplasia, failure to thrive, developmental delay, and mental retardation. ${ }^{5}$ Apart from unbalanced chromosome translocations involving distal $15 \mathrm{q}$ and ring chromosome 15 syndromes, there are only seven previously described patients with de novo deletions of the distal long arm of chromosome $15 .^{1-7}$ Most of these patients had interstitial deletions with different breakpoints indicating that the phenotypic discordance observed probably results from differences in the size and localisation of the deleted material.

Similarly to patients with distal deletion of $15 \mathrm{q}$, many patients with ring chromosome 15 syndrome showed symptoms like IUGR, mental retardation, and microcephaly, but they more frequently had a triangular face, hypertelorism, café au lait spots, cryptorchidism, cardiac anomalies, and brachydactyly. ${ }^{18}$

To the best of our knowledge there are only two comparable cases to our patient with a deletion of 15q26.1 (table 2) that have been investigated by molecular genetic techniques. $^{5618}$ These patients and our patient share intrauterine growth retardation, poor growth and development, and minor anomalies of the face. The female child described by Siebler $e t a l^{6}$ also had a triangular face and brachydactyly and exhibited characteristics of patients with ring chromosome 15 syndrome and deletion of $15 \mathrm{q} 26.1$. Renal malformations were only reported in the case of Roback et $a \bar{l}$ and our case. The patient of Roback et al also had lung hypoplasia, while our patient suffered from a complex heart defect. Feeding difficulties, as in our patient, were reported in four cases out of seven.

Only a couple of genes have been mapped to date in the distal part of chromosome 15, one of which is IGF1R (OMIM, http:// www3.ncbi.nlm.nih.gov/htbin-post/Omim/ getmap? chromosome $=15 \mathrm{q} 26)$. It has been proposed that haploinsufficiency of the IGF1R gene, which has been assigned to $15 \mathrm{q} 25-\mathrm{q} 26,{ }^{19}$ may play a role in the growth deficiency seen in patients with distal deletions of 15q25-26. Roback et $a p^{\overline{5}}$ refined the mapping of IGF1R distal to $15 \mathrm{q} 26.1$ by deletion mapping. These findings were corroborated by Southern blot analysis of two patients with deletions of $15 \mathrm{q} 26.1 .^{6}$ The IGF1R gene locus lies physically between the STS markers D15S107 and D15S87. ${ }^{16}$ Therefore, IGF1R is also deleted in our patient who displayed extreme pre- and postnatal growth retardation.

Peoples et $a l^{16}$ investigated five children with de novo ring chromosomes 15 with breakpoints in $15 \mathrm{q} 26.3$ showing monozygosity of the IGF1R gene in three of them. These three children had significantly more severe growth retardation in the first few years of life than one patient who retained the IGF1R gene on the ring chromosome. These data support a correlation between monozygosity for the IGF1R gene and severe growth retardation in early childhood, while patients who have retained two copies of the IGF1R gene show milder growth retardation. ${ }^{20}$

In vitro studies of fibroblasts of the two patients described by Siebler et $a l^{6}$ showed that IGF1 receptor expression was decreased, while there was no evidence for impairment of the response to IGF1. Thus, Siebler et al suggested that the growth retardation might not be related to monozygosity for IGF1R. However, the authors conceded that extrapolation from findings in skin fibroblasts to the situation in vivo is difficult.

De Lacerda $e t a l^{21}$ were the first to describe in vitro and in vivo studies of a patient with ring chromosome 15 syndrome and monozygosity for IGF1R. The female child showed prenatal and severe postnatal growth failure, a slightly triangular face, high arched palate, café au lait spots, and delayed psychomotor development. The patient's fibroblasts exhibited growth 
response in vitro to the addition of IGF1, similar to that of control fibroblasts. In contrast, the treatment of the child with short term recombinant human IGF1 (rhIGF1) caused no significant reduction in urinary urea nitrogen excretion, only $60 \%$ increase in calcium excretion, and no significant decrease in the $\mathrm{GH}$ secretion. Therefore, the authors suggested that the growth retardation could be the result of the absence of one IGF1R allele because of in vivo resistance to IGF1.

Studies on the effects of IGF1R in the cardiovascular system may support this assumption. These data showed evidence that IGF1 is an essential regulator of developmental growth and plays an important role in cardiovascular development. ${ }^{22} \mathrm{~A}$ variety of growth factors upregulate IGF1R on vascular smooth muscle cells and the data support the concept that IGF1R number per cell is an important factor for cellular growth response.

Therefore, monozygosity for IGF1R would be the best explanation for the complex heart defect seen in our patient. Thus, in addition to severe growth retardation, monozygosity for $I G F 1 R$ might be a risk factor for the development of complex heart defects.

We thank the Max-Planck-Institute of Molecular Genetics, Berlin, for the YAC clones. The authors thanks Antje Gerlach and Britta Teubner for excellent technical assistance in the molecular cytogenetic experiments.

1 Fryns JP, de Muelenaere A, van den Berghe H. Interstitial deletion of the long arm of chromosome 15. Ann Genet 1982;25:59-60.

2 Clark RD. Del(15)(q22q24) syndrome with Potter sequence. Am f Med Genet 1984;19:703-5.

3 Formiga LD, Poenaru L, Couronne F, Flori E, Eibel JL, Deminatti MM, Savary JB, Lai JL, Gilgenkrantz S, Pierson M. Interstitial deletion of chromosome 15: two cases. Hum Genet 1988;80:401-4

4 Ulm JE, Shah DM, Dev VG, Phillips JA III. Counseling and decision dilemmas associated with fetal blood sampling. Am $\mathcal{7}$ Med Genet 1990;35:75-8.

5 Roback EW, Barakat AJ, Dev VG, Mbikay M, Chretien M, Roback EW, Barakat AJ, Dev VG, Mbikay M, Chretien M,
Butler MG. An infant with deletion of the distal long arm Butler MG. An infant with deletion of the distal long arm
of chromosome 15 (q26.1qter) and loss of insulin-like growth factor I receptor gene. Am $\mathcal{f}$ Med Genet 1991;38:749 .

6 Siebler T, Lopaczynski W, Terry CL, Casella SJ, Munson P, De Leon DD, Phang L, Blakemore KJ, McEvoy RC, Kelley RI, Nissley P. Insulin-like growth factor I receptor expression and function in fibroblasts from two patients with deletion of the distal long arm of chromosome $15 . \mathscr{f}$ Clin Endocrinol Metab 1995;80:3447-57.

7 Verma RS, Kleyman SM, Giridharan R, Ramesh KH. A de novo interstitial deletion of chromosome 15 band 925 as revealed by FISH-technique. Clin Genet 1996;49:303-5.
8 Ullrich A, Gray A, Tam AW, Yang-Feng T, Tsubokawa M, Collins C, Henzel W, Le Bon T, Kathuria S, Chen E, Jacobs S, Francke U, Ramachandran J, Fujita-Yamaguchi T. Insulin-like growth factor I receptor primary structure: comparison with insulin receptor suggests structural determinants that define functional specificity. $E M B O f$ 1986;10:2503-12

9 Telenius H, Carter NP, Nordenskjold M, Ponder BA, Yunnacliffe A. Degenerate oligonucleotide-primed PCR: general amplification of target DNA by a single degenerate primer. Genomics 1992;13:718-25.

10 Kallioniemi OP, Kallioniemi A, Piper J, Isola J, Waldman FM, Gray JW, Pinkel D. Optimizing comparative genomic hybridization for analysis of DNA sequence copy number changes in solid tumors. Genes Chrom Cancer 1994;10:23143.

11 Larramendy ML, El-Rifai W, Knuutila S. Comparison of fluorescein isothiocyanate- and Texas red-conjugated nucleotides for direct labeling in comparative genomic hybridization. Cytometry 1998;31:174-9.

12 Dib C, Fauré S, Fizames C, Samson D, Drouot N, Vignal A, Millasseau P, Marc S, Hazan J, Seboun E, Lathrop M, Gyapay G, Morissette J, Weissenbach J. A comprehensive genetic map of the human genome based on 5,264 microsatellites. Nature 1996;380:152-4.

13 Broman KW, Murray JC, Sheffield VC, White RL, Weber JL. Comprehensive human genetic maps: individual and sex-specific variation in recombination. Am 7 Hum Genet 1998;63:861-9.

14 Mitelman F, ed. ISCN (1995). An international system for human cytogenetic nomenclature. Basel: Karger, 1995.

15 Deloukas P, Schuler GD, Gyapay G, Beasley EM, Soderlund C, Rodriguez-Tome P, Hui L, Matise TC, McKusick KB, Beckmann JS, Bentolila S, Bihoreau M, Birren BB, Browne J, Butler A, Castle AB, Chiannilkulchai N, Clee C, Day PJ, Dehejia A, Dibling T, Drouot N, Duprat S, Fizames C, Fox S, Gelling S, Green L, Harrison P, Hocking R, Holloway E, Hunt S, Keil S, Lijnzaad P, Louis-Dit-Sully C, Ma J, Mendis A, Miller J, Morissette J, Muselet D, Nusbaum HC, Peck A, Rozen S, Simon D, Sloim DK, Staples R, Stein LD, Stewart EA, Such D, Slonim DK, Staples R, Stein LD, Stewart EA, Suchard MA, Thangarajah T, Vega-Czarny N, Webber C, Wu X, Hudson J, Auffray C, Nomura N, Sikela JM, Polymeropoulos MH, James MR, Lander ES, Hudson TJ, Myers RM, Cox DR, Weissenbach J, Boguski MS, Bentley DR. A phys

16 Peoples R, Milatovich A, Francke U. Hemizygosity at the insulin-like growth factor I receptor (IGF1R) locus and growth failure in the ring chromosome 15 syndrome. Cytogenet Cell Genet 1995;70:228-34.

17 Varley H, Di S, Scherer SW, Royle NJ. Characterization of terminal deletions at $7 \mathrm{q} 32$ and $22 \mathrm{q} 13.3$ healed by de novo telomere addition. Am f Hum Genet 2000;67:610-22.

18 Butler MG, Fogo AB, Fuchs DA, Collins FS, Dev VG, Phillips JA. Brief clinical report and review. Two patients with ring chromosome 15 syndrome. Am f Med Genet 1988;29: $149-54$

19 Francke U, Yang-Feng TL, Brissenden JE, Ullrich A. Chromosomal mapping of genes involved in growth control. Cold Spring Harbor Symp Ouant Biol 1986;51:855-66.

20 Kosztolanyi G. Does "ring syndrome" exist? An analysis of 207 case reports on patients with a ring autosome. Hum Genet $1987 ; 75: 174-9$.

21 de Lacerda L, Carvalho JAR, Stannard B, Werner H, Boguszewski MCS, Sandrini R, Malozowski SN, LeRoith D, Underwood LE. In vitro and in vivo responses to shortterm recombinant human insulin-like growth factor-1 (IGF-I) in a severely growth-retarded girl with ring chromosome 15 and deletion of a single allele for the type 1 IGF receptor gene. Clin Endocrinol 1999;51:541-50.

22 Delafontaine P. Insulin-like growth factor I and its binding proteins in the cardiovascular system. Cardiovasc Res 1995; 30:825-34.
7 Med Genet 2001;38:621-624

Centre for Human

Genetics, University of

Leuven, Herestraat 49,

B-3000 Leuven,

Belgium

M Syrrou

J-P Fryns

Correspondence to:

Professor Fryns

Jean-Pierre.Fryns@

med.kuleuven.ac.be

\section{Interstitial deletion of chromosome 11 (q22.3-q23.2) in a boy with mild developmental delay}

\author{
M Syrrou, J-P Fryns
}

EDITOR-Deletions of the terminal region of the long arm of chromosome 11 (bands 11q23.3-11q24) are associated with a clinically recognisable phenotype, also called Jacobsen syndrome (JS). ${ }^{1}$ Reports on more proximal $11 \mathrm{q}$ deletions are rare. This is the second report describing a de novo interstitial deletion of the $11 \mathrm{q} 22.3-\mathrm{q} 23.2$ region. The first described a de novo interstitial deletion of the 11q22.3-q23.2 region in a mildly retarded male with minor 
dysmorphic signs (high and narrow palate, low set, dysplastic ears, small hands and feet, and slender fingers) and epileptic seizures. ${ }^{2}$ However, no FISH studies were performed in this patient.

In this report we describe a small de novo interstitial deletion in the long arm of chromosome 11 (bands q22.3-q23.2) in a 2 year 8 month old boy with mild developmental delay and without major associated dysmorphic features or a clinically recognisable phenotype.

\section{Case report}

The proband, a boy, is the second and youngest child of healthy, non-consanguineous parents. His 5 year old sister is normal. Pregnancy and delivery, at 39 weeks, were normal. Birth weight was $3130 \mathrm{~g}$, length $49 \mathrm{~cm}$, and head circumference $33.5 \mathrm{~cm}$. Clinical examination in the neonatal period was normal, apart from mild axial hypotonia. Motor development was slightly retarded and he walked without support at the age of 17 months.

Now, at the age of 2 years 8 months, psychomotor development is borderline normal (2 years 2 months to 2 years 4 months on the Bayley Developmental scale). Social contact is adequate but expressive language is mildly retarded at a developmental level of 2 years. Height is $89.5 \mathrm{~cm}$ (10th centile), weight 12.5 $\mathrm{kg}$ (10th centile), and head circumference 48 $\mathrm{cm}$ ( $3 \mathrm{rd}$ centile for age). Except for the relative microcephaly and mild trigonocephaly, craniofacial dysmorphism is mild and non-specific, including a somewhat large mouth with a thin upper lip and everted lower lip and rather large and everted ears. Both thumbs are proximally implanted. Further clinical and neurological examinations were normal. Additional examinations including MRI scan of the brain, metabolic screening, and ophthalmological examination were normal.

Cytogenetic studies were performed using PHA stimulated lymphocytes according to standard cytogenetic procedures. G banded chromosome analysis showed an interstitial deletion of the long arm of chromosome 11 (q22.2-q23.1) (fig 1). The karyotype was 46,XY,del(11) (pter $\rightarrow$ q22.3::q23.1 $\rightarrow$ qter).

The parental karyotypes were normal.

FISH with chromosome 11 specific paint probe (Cambio) showed no translocation of chromosome 11 material (fig 2A). FISH analysis was performed with five YAC probes (878C12, 876G04, 801E11，755B11, and 742F09), BAC442e11, and three cosmid probes that map to the $11 \mathrm{q} 22-11 \mathrm{q} 23$ region. BAC442e11(RPC11 human BAC library, Roswell Park Cancer Institute) has been recently reported and spans the $\mathrm{t}(11 ; 22)$ breakpoint on chromosome $11 .^{3}$ Cosmid probes 4746 and 4748 cover the $M L L$ gene region and $2072 \mathrm{c} 1$ is a subtelomeric probe (table 1$){ }^{4}$

FISH results defined the extent of the deletion (from q22.3 and q23.2). The proximal boundary of the deleted region is between D11S1762/D11S1339 and D11S1167 because FISH with YAC878C12 gave a signal on the deleted chromosome, whereas the terminal

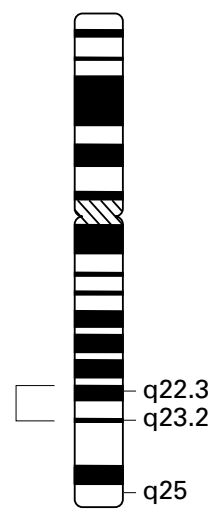

11

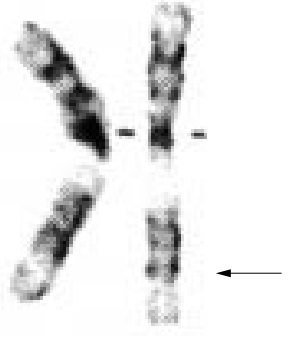

11 del (11)
Figure 1 Partial $G$ banded karyotype showing the normal chromosome 11 (on the left) and the deleted chromosome 11 (on the right). An ideogram of chromosome 11 is also shown. The deleted region is indicated by brackets.

boundary is placed proximal to the $M L L$ locus (fig 2B, C, D, E, F). Chromosomes were viewed with a Zeiss Axioplan epifluorescence microscope. For digital image analysis the Cytovision System (Applied Imaging) was used.

\section{Discussion}

Chromosomal region 11q22-q23 is apparently prone to instability (recombination, breakage, or rearrangement). The breakpoints of the classical constitutional $t(11 ; 22)$ and the breakpoints in the majority of cases with terminal $11 \mathrm{q}$ deletions and derivative chromosomes 11 are located in this region. This region is often involved in multiple tumour associated rearrangements of chromosome 11 and distally lies the $M L L$ gene region that is frequently rearranged in haematopoietic malignant disorders. $^{5}$ On the telomeric side of $M L L$ is the fragile site FRA11B and also the Jacobsen syndrome breakpoints (11q23.3-11q24.2). ${ }^{13}$ Consequently the region could be considered as a hot spot of chromosomal recombination and breakage.

In this case, the deletion is smaller than the previously reported deletions on $11 \mathrm{q}$, for example, deletions critical for the diagnosis of Jacobsen syndrome (MIM 147791) ${ }^{1}$ or larger deletions involving the $11 \mathrm{q} 22-\mathrm{q} 23 \rightarrow 11 \mathrm{qter}$ region. ${ }^{6-9}$

The fragile site at $11 \mathrm{q} 23.3$ (FRA11B) is linked to some Jacobsen syndrome breakpoints ( $10 \%$ of the cases) but the majority are located distal to FRA11B. It was proposed that JS is not a single disease but a collection of different genetic disorders with overlapping phenotypes. The phenotypic variability observed is because of the variation of breakpoints and the different genes involved. ${ }^{1011}$ Thus, the $11 \mathrm{q} 22.3-\mathrm{q} 32.2$ deletions in the present patient could be considered as a part of the spectrum of $11 \mathrm{q}$ deletions resulting from a similar mechanism, with the more distal deletions resulting in Jacobsen syndrome and the more proximal resulting in a milder phenotype.

In the present case, Bac442e11, which spans the $t(11 ; 22)$ breakpoint in $11 \mathrm{q} 23$, was deleted. This BAC clone is related to a palindromic AT 
rich region. ${ }^{12}$ The mechanism of formation of the deletion in the reported case could be consistent with the one proposed by Akgun et al. ${ }^{13}$ They proposed that in mammals palindromic DNA sequences can lead to the formation of unstable DNA structures, such as single stranded hairpin and double stranded cruciform structures, and they hypothesised that a small disruption of symmetry in the palindrome could stabilise the locus. To explain their results, they proposed two different models that could explain the formation of deletions and translocations. According to one model, replication slippage could result in two sided palindrome deletions spanning the tip of the hairpin and create a product with a deletion in the palindrome. This mechanism could explain the deletion in the present patient. According to the
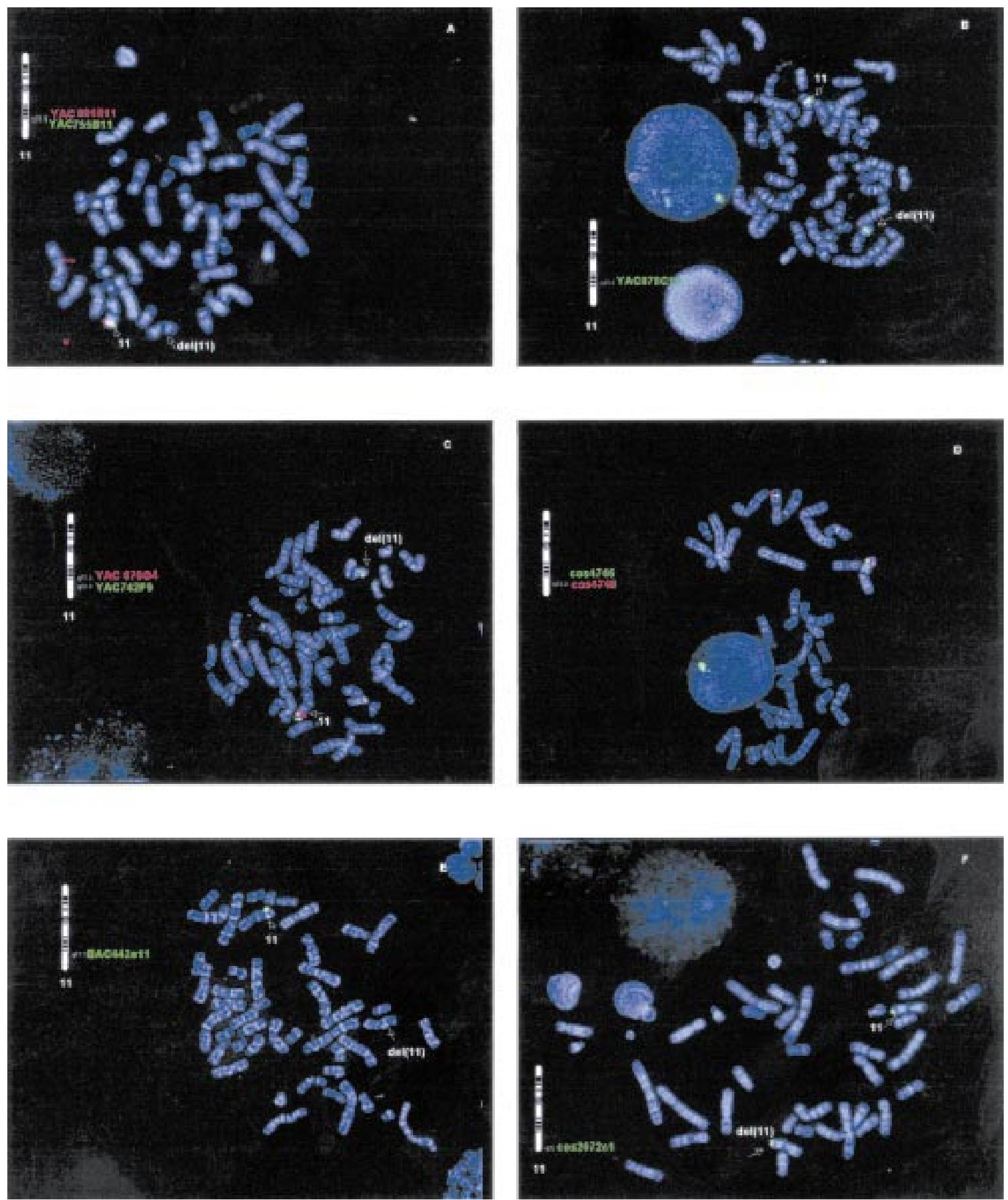

Figure 2 (A) Hybridisation with YAC 801E11 and YAC 755B11. (B) Hybridisation with YAC 878C12. (C) Hybridisation with YAC 876G04 and 742F09. (D) Hybridisation with cos 4746 and cos 4748. (E) Hybridisation with BAC442e11. (F) Hybridisation with cosmid 2072c1. An explanation for the mechanism of the deletion has been included. 
Table 1 FISH data

\begin{tabular}{lllll}
\hline Probe & STS markers covered & & Result & $\begin{array}{l}\text { Cytogenetic } \\
\text { position }\end{array}$ \\
\hline YAC878C12 & D11S1762/D11S1339 & - D11S1167 & + & $\mathrm{q} 22.2$ \\
YAC876G04 & D11S817 & - Y734D08L & - & $\mathrm{q} 22.3$ \\
YAC801E11 & D11S384 & - D11S1897 & - & $\mathrm{q} 22.3$ \\
YAC755B11 & D11S1960 & - Y296F0FR & - & $\mathrm{q} 23.1$ \\
BAC442e11 & D11S1340 & - D11S4516 & - & $\mathrm{q} 23.2$ \\
Cos4746 & MLL & & + & $\mathrm{q} 23.3$ \\
Cos4748 & MLL & & + & $\mathrm{q} 23.3$ \\
YAC742F09 & D11S461/D11S939 & - HLR2 & + & $\mathrm{q} 23.3$ \\
Cos2072c1 & (Subtelomere) & & + & $\mathrm{q} 25$ \\
\hline
\end{tabular}

(+) Hybridisation to both chromosomes 11. (-) Hybridisation only to normal chromosome 11.

second model, a single strand nick in the tip of the hairpin could result in a double strand break and then lead to illegitimate recombination. The second model could be consistent with the formation of the $\mathrm{t}(11 ; 22) .^{13}$

1 Tunnacliffe A, Jones C, Le Paslier D, Todd R, Cherif D, Birdsall M, Devenish L, Yousry C, Cotter FE, James MR. Localization of Jacobsen syndrome breakpoints on a $40-\mathrm{Mb}$ physical map of distal chromosome 11q. Genome Res 1999;9:44-52.

2 De Pater JM, Ippel PF, Bijlsma JB, Van Nieuwenhuizen O. Interstitial deletion $11 \mathrm{q}$ case report and review of the literature. Genet Couns 1997;8:335-9.

3 Shaikh TH, Budarf ML, Celle L, Zackai EH, Emanuel BS. Clustered 11q23 and 22q11 breakpoints and 3:1 meiotic malsegregation in multiple unrelated $\mathrm{t}(11 ; 22)$ families. $\mathrm{Am}$ malsegregation in multiple unrelat

7 Med Genet 2001;38:624-629

4 National Institutes of Health and Institute for Molecular Medicine Collaboration. A complete set of human telomeric probes and their clinical application. Nat Genet 1996;14:86-9.

5 O'Hare AE, Grace E, Edmunds AT. Deletion of the long arm of chromosome 11(46,XX, del(11)(q24.1-qter). Clin Genet 1984;25:373-7.

6 Fryns JP, Kleczkowska A, Buttiens M, Marien P, Van den Berghe H. Distal 11q monosomy. The typical 11q monosomy syndrome is due to deletion of subband 11q24.1. Clin Genet 1986;30:255-60.

7 Penny LA, del Aquila M, Jones MC, Bergoffen JA, Cunniff C, Fryns JP, Grace E, Graham JM, Kousseff B, Mattina T, Syme J, Voullaire L, Zelante L, Zenger-Hain J, Jones OW, Evans GA. Clinical and molecular characterisation of patients with distal $11 \mathrm{q}$ deletions. Am $\mathcal{F}$ Hum Genet 1995;56:676-83.

8 Leegte B, Kerstjens-Frederikse WS, Deelstra K, Begeer JH, Van Essen AJ. 11q- syndrome: three cases and a review of the literature. Genet Couns 1999;10:305-13.

9 Arai Y, Hosoda F, Nakayama K Ohki M. A yeast artificial chromosome contig and NotI restriction map that spans the tumor suppressor gene(s) locus, 11q22.2-q23.3. Genomics 1996;35:195-206.

10 Jones C, Mullenbach R, Grossfeld P, Auer R, Favier R, Chien K, James K, Tunnacliffe A, Cotter F. Co-localisation of CCG repeats and chromosome deletion breakpoints in Jacobsen syndrome: evidence for a common mechanism of chromosome breakage. Hum Mol Genet 2000;9:1201-8.

11 Michaelis RC, Vegaleti GVN, Jones C, Pivnick EK, Phelan MC, Boyd E, Tarleton J, Wilroy RS, Tunnackliffe A, Tharapel AT. Most Jacobsen syndrome deletion breakpoints occur distal to FRA11B. Am $\mathcal{f}$ Med Genet 1998;76:222-8.

12 Kurahashi H, Shaikh TH, Ping H, Roe BA, Emanuel BS, Budarf ML. Regions of genomic instability on 22q11 and $11 \mathrm{q} 23$ as the etiology for the recurrent constitutional $t(11$; 22). Hum Mol Genet 2000;9:1665-70.

13 Akgun E, Zahn J, Baumes S, Brown G, Liang F, Romanienko PJ, Lewis S, Jasin M. Palindrome resolution and recombination in the mammalian germ lien. Mol Cell Biol 1997;17:559-70.
Molecular Genetics Laboratory, Auckland Hospital, Auckland,

New Zealand M R Hegde

B Chong

M Fawkner

Institute of Medica

Genetics, Medical

School Charite,

Humboldt University,

D-10098 Berlin,

Germany

N Lambiris

$\mathrm{H}$ Peters

Howard Hughes

Medical Institute,

Emory University

School of Medicine,

1510 Clifton Road,

Room 4035 Rollins

Research Center,

Atlanta, Georgia

30322, USA

A Kenneson

S T Warren

Molecular Genetics and Development

Group, School of

Biological Sciences,

University of

Auckland, Private Bag

92019, Auckland, New

Zealand

D R Love

Northern Regional

Genetics Service,

Building 18, Auckland

Hospital, Park Road,

Grafton, U

Correspondence to:

Dr McGaughran

JulieMc@ahsl.co.nz

\section{Microdeletion in the FMR-1 gene: an apparent null allele using routine clinical PCR amplification}

Madhuri R Hegde, Belinda Chong, Matthew Fawkner, Nikolas Lambiris, Hartmut Peters, Aileen Kenneson, Stephen T Warren, Donald R Love, Julie McGaughran

EDITOR-Fragile $\mathrm{X}$ syndrome is the most common chromosomal cause of inherited mental retardation. At the chromosome level, this syndrome is characterised by the presence of a fragile site at $\mathrm{Xq} 27.3 .^{1}$ The incidence of this disorder is approximately 1 in 4000 and 1 in 7000 in males and females, respectively. ${ }^{23}$ In most cases, the mutation responsible for fragile $\mathrm{X}$ syndrome is a CGG repeat expansion in the 5 ' untranslated region (UTR) of exon 1 of the FMR-1 gene. People in the normal population have six to approximately 50 repeats. ${ }^{45}$ Those with 50 to 200 repeats correspond to the premutation class. Repeats in this class are meiotically unstable and can expand to a full mutation. ${ }^{4}$ The premutation class encompasses the "grey area" of 45-55 CGG repeats for which there is a variable risk of repeat expansion. ${ }^{6}$ Subjects with a full mutation have repeat lengths in excess of 200, which are associated with hypermethylation of the $\mathrm{CpG}$ island immediately upstream of the FMR-1 gene. $^{7-9}$ This methylation correlates with transcriptional suppression of the FMR-1 gene, while the repeat expansion has been suggested to cause translational suppression by impeding the migration of the $40 \mathrm{~S}$ ribosomal subunit along the 5' UTR of the FMR-1 gene transcript. ${ }^{9-11}$

Fragile $\mathrm{X}$ syndrome has also been found to occur in a few patients without CGG repeat expansions. These mutation events fall into two classes, intragenic point mutations ${ }^{12}{ }^{13}$ and deletion events. ${ }^{14-22}$ Of the latter class, five patients with microdeletions in the 5' UTR of the FMR-1 gene transcript have been described. ${ }^{23} 24$

We report here a patient referred for fragile $\mathrm{X}$ testing who was found to carry an apparent null allele by PCR amplification of the CGG repeat region of the FMR-1 gene. This patient was analysed further using a combination of primers flanking the CGG repeat region, together with FMRP studies, in order to characterise the nature of the molecular defect underlying this apparent null allele.

\section{Case report}

The proband was born to healthy, nonconsanguineous parents at 40 weeks of gestation. There was no significant family history. $\mathrm{He}$ weighed $4500 \mathrm{~g}$ (>90th centile), head circumference was $37.5 \mathrm{~cm}$ (>90th centile), and length was $57.5 \mathrm{~cm}$ (>90th centile). There 
was aspiration of meconium at delivery necessitating assessment in the neonatal unit. $\mathrm{He}$ appeared well initially but on the following day was noted to be irritable and hypotonic with an abnormal Moro reflex. A cranial ultrasound scan was normal. He required an inguinal hernia repair at a few weeks of age. His early development was felt to be normal. He had gastro-oesophageal reflux diagnosed at 8 months and was treated with ranitidine. $\mathrm{He}$ had mild plagiocephaly and a torticollis that required surgical correction at 18 months. $\mathrm{He}$ had persistent problems with drooling of saliva and tends to have an open mouthed expression. In the second year of life he had problems with recurrent ear infections requiring insertion of grommets and adenoidectomy. An assessment at the age of 3 years showed his speech and language development to be significantly delayed. His parents felt his comprehension was limited and he had difficulty retaining information. The delay had been noted earlier but had been attributed to his recurrent ear infections. Full assessment at that time showed that he had developmental delay in all areas. $\mathrm{He}$ had some behavioural problems with trichotillomania and obsessive traits. He did not play well with other children.

On examination by a clinical geneticist, the proband was found not have any phenotypic features suggestive of fragile $\mathrm{X}$ syndrome, although he did have early features of joint laxity. His head circumference was on the 50th-90th centile, his height on the 75 th centile, and weight on the 50th centile. He had mild clinodactyly and fetal pads. He had mild facial asymmetry and a deep crease between his first and second toes. Examination was otherwise unremarkable. The case was referred to the laboratory for fragile X screening.

\section{Materials and methods}

CYTOGENETIC AND DNA ANALYSIS

Cytogenetic analysis of a folate deprived culture of lymphocytes was performed as previously described. ${ }^{25}$ An estimation of the length of the CGG repeats, together with an analysis of the methylation status of the $\mathrm{CpG}$ island of the FMR-1 gene, were performed by PCR amplification and Southern blot analysis, respectively. In the case of the latter, $5 \mu \mathrm{g}$ of genomic DNA was digested with EcoRI and NruI, electrophoretically separated, blotted onto a positively charged nylon membrane, and hybridised with approximately 10-20 ng of probe StB12.3, as described previously. ${ }^{26}$ The hybridisation solution contained herring sperm DNA at $75 \mu \mathrm{g} / \mathrm{ml}$ to prevent non-specific binding of the probe. The blots were washed finally in $0.2 \times \mathrm{SSC}$ plus $0.1 \% \mathrm{SDS}$ at $60^{\circ} \mathrm{C}$. DNA controls included a normal male, a male with a full mutation (expanded CGG repeat with hypermethylation of the $\mathrm{CpG}$ island), a female with a premutation, and a normal female control. A radioactively labelled $1 \mathrm{~kb}$ ladder was included for sizing purposes.

PCR amplification of the CGG repeat region of the FMR-1 gene using primers FMRA and FMRB was carried out in $15 \mu \mathrm{l}$ reactions. Each reaction comprised $10 \%$ DMSO, $50 \% \mathrm{w} / \mathrm{v}$ glycerol, $60 \mathrm{pmol}$ of each primer, $0.4 \mathrm{U}$ of Taq DNA polymerase, $1 \times$ PCR buffer with $0.32 \mathrm{mmol} / 1$ of dCTP, dATP, dTTP, and $1.5 \mathrm{mmol} / 1$ deaza GTP, $0.25 \mu \mathrm{l}$ of $10 \mu \mathrm{Ci} \mu \mathrm{l} \alpha^{32} \mathrm{P} \mathrm{dCTP}$, and 0.6 $\mathrm{mg} / \mathrm{ml}$ genomic DNA. Non-radioactive PCR amplification using primers FMR1 and FMR2 was carried out using the GC rich kit of Roche Diagnostics Ltd according to the manufacturer's instructions. The sequences of the primers used in the amplification reactions were FMRA (5'-GACGGAGGCGCCCGTGCCAGG-3'), FMRB (5'-TCCTCCATCTTCTCTTCAGC CCT-3'), FMR1 (5'-ATAACCGGATGCA TTTGAT-3'), and FMR2 (5'-AGGC CCTAGCGCCTATCGAAATGAGAGA-3'). Primers FMR1, FMRA, FMRB, and FMR2 were designed using the $F M R-1$ gene sequence deposited in GenBank (Accession number X61378), with their 5 ' ends at base positions 2271, 2684, 2844, and 3106, respectively. The PCR cycling conditions comprised $95^{\circ} \mathrm{C}$ for two minutes followed by 30 cycles of $97^{\circ} \mathrm{C}$ for 30 seconds, $55^{\circ} \mathrm{C}$ for one minute, and $72^{\circ} \mathrm{C}$ for one minute. The reactions were held at $4^{\circ} \mathrm{C}$ following a final extension of $72^{\circ} \mathrm{C}$ for $10 \mathrm{~min}$ utes. Amplification products were electrophoresed in a $1 \%$ agarose gel, together with a $100 \mathrm{bp}$ DNA ladder. In the case of radioactive amplification, the products were electrophoresed in a denaturing sequencing gel using a radioactively labelled M13 sequencing ladder for sizing purposes.

Amplification products were purified for sequencing using a PCR purification kit (Roche Diagnostics). Each amplicon was sequenced using the forward and reverse amplifying primers and an Applied Biosystems (ABI) sequencing kit. DNA was recovered by ethanol precipitation and subsequently washed in $70 \%$ ethanol before the addition of denaturation buffer and loading in an ABI PRIS$M^{\mathrm{TM}} 377$ DNA sequencer. The electropherograms were subsequently assembled using SeqMan DNA software.

\section{PROTEIN ANALYSIS}

An EBV transformed B lymphoblastoid cell line was established from a peripheral blood sample of the proband. FMRP and eIF4e levels were determined in whole cell lysates in a slotblot based assay, using purified flag tagged murine Fmrp ${ }^{27}$ and purified human $\mathrm{eIF} 4 \mathrm{e}^{28}$ as standards. Sample proteins and standards were applied to nitrocellulose membranes with a Bio-Rad slot blot apparatus. Using standard protocols, FMRP and eIF4e were detected with mouse monoclonal primary antibodies mAb 1C3 for FMRP, kindly provided by JeanLouis Mandel, ${ }^{29}$ and anti-eIF4e (Transduction Laboratories) and HRP conjugated goat antimouse secondary antibody (Kirkegaard and Perry Laboratories). Signals were generated by Enhanced Chemi Luminescence (Amersham) and detected by exposure to Hyperfilm (Amersham). Signal intensities were quantified by analysis of digital scans using the program NIH Image $1.62 \mathrm{~b} 7 \mathrm{f}$ to plot signal profiles. Areas under the plot profile were calculated and used as signal intensities after subtracting out signals 
A

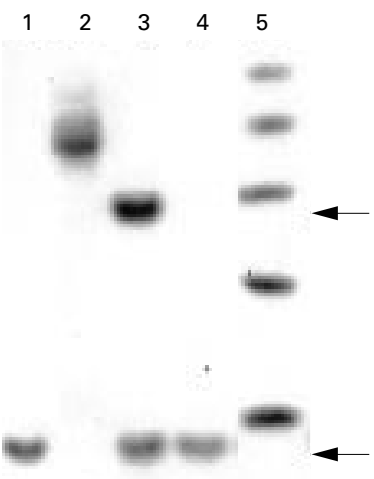

B

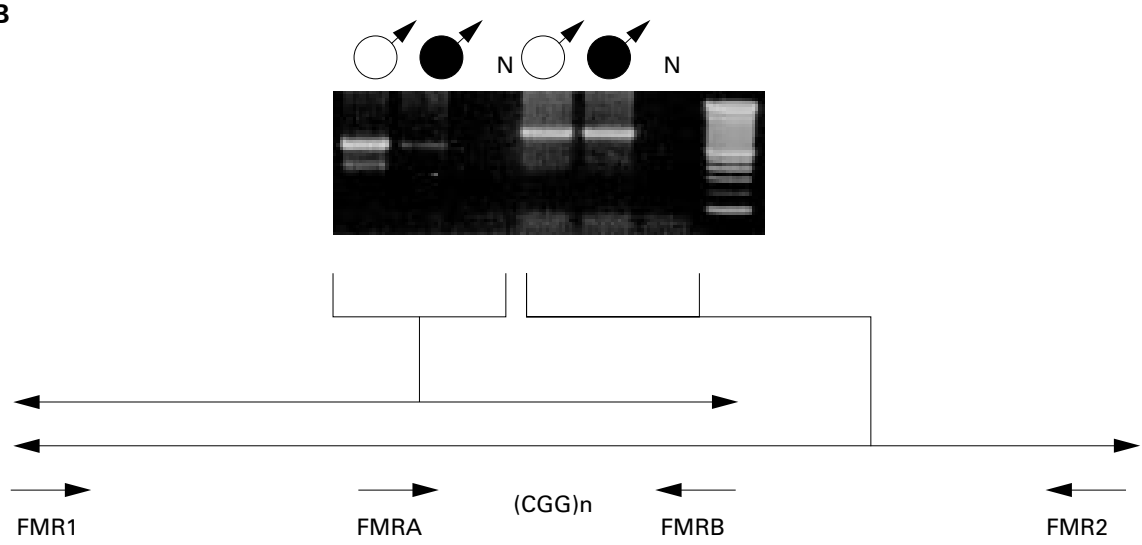

C
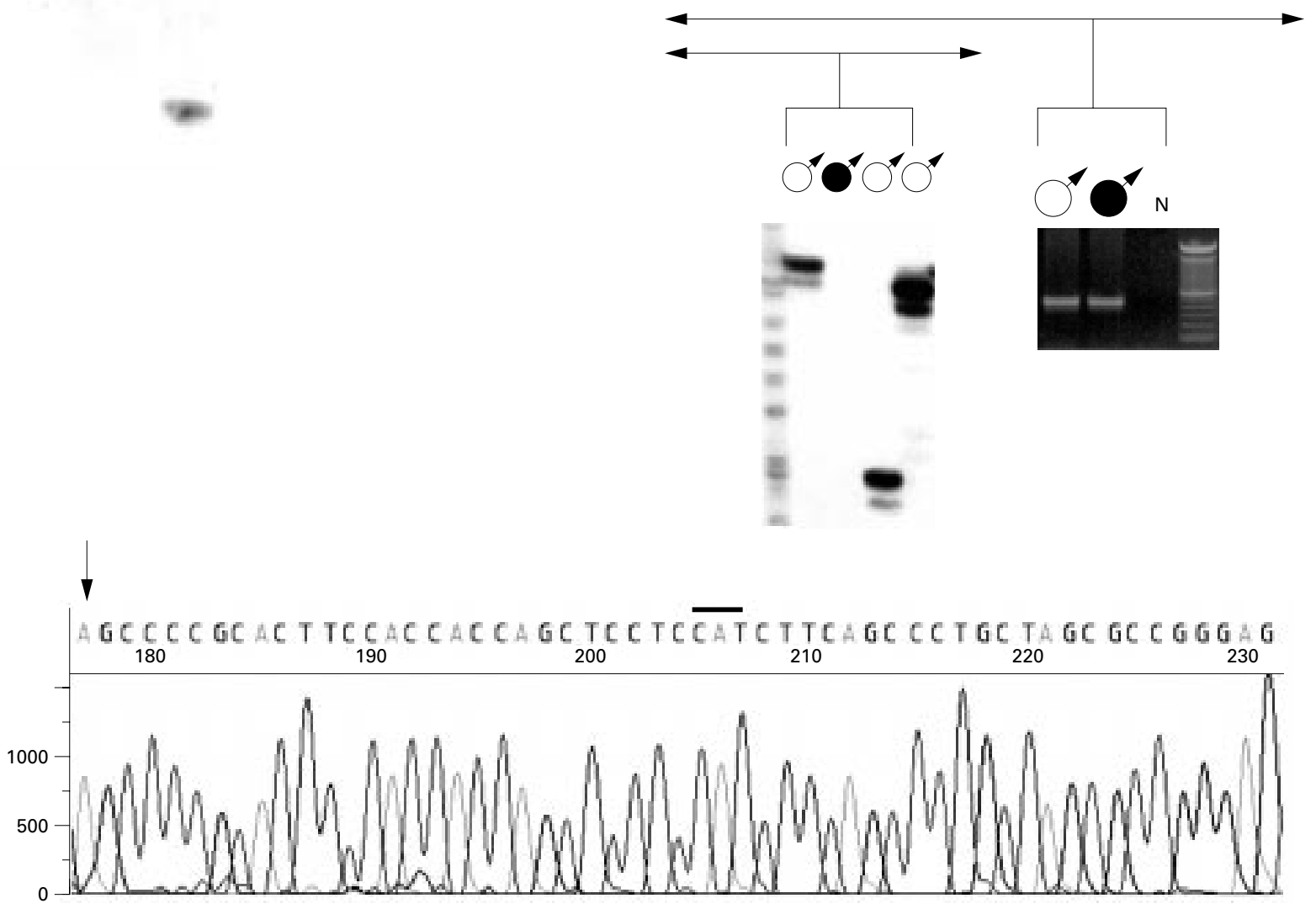

D

25

FMRA

GACGGAGGCG $\quad$ CCGCTGCCAG

GGGGCGTGCG GCAGCG ( CGG )n

CTGGGCCTCG

AGCGCCCGCA

GCCCACCTCT

CGGGGGCGGG

CTCCCGGCGC

TAGCAGGGCT

GAAGAGAAGA

TGGAGGAGCT

GGTGGTGGAA

GTGCGGGGCT

\section{7}

Figure 1 DNA analysis of the CGG repeat region of the FMR-1 gene. (A) EcoRI plus NruI digested genomic DNA from a normal male (lane 1), a male with a full mutation (lane 2), a normal female (lane 3), and the proband (lane 4) was probed with StB12.3. The $1 \mathrm{~kb}$ ladder is shown in lane 5, with the lengths of the unmethylated and methylated alleles in a normal subject indicated on the right hand side of the panel. (B) PCR amplification products encompassing the CGG repeat region of the FMR-1 gene are shown. The proband and normal males are represented by the filled and open symbols, respectively, while negative PCR controls are indicated by the letter $N$. The radioactively labelled products corresponding to PCR amplification using primers FMRA and FMRB were electrophoresed in a denaturing sequencing gel with a labelled M13 sequencing ladder, while the other amplification products were separated in $1 \%$ agarose gels with $100 \mathrm{bp}$ ladders. (C) Electropherogram of the sequence of the proband's FMR-1 gene encompassing the ATG initiation codon (indicated by a horizontal bar). The sequence is shown in the 3' to 5' direction. The vertical arrow indicates an arbitrary start site for the sequence presented in (D). (D) Partial sequence of the FMR-1 gene (GenBank accession number X61378) indicating the GAAGA direct repeats (in bold type and numbered horizontal arrows) and the ATG initiation codon (underlined). The location of the FMRA and FMRB primers are shown as horizontal arrows, together with their position with respect to the transcription start site. The nucleotide sequence derived from the electropherogram is shown starting at an arbitrary site, indicated by an arrow. 
A
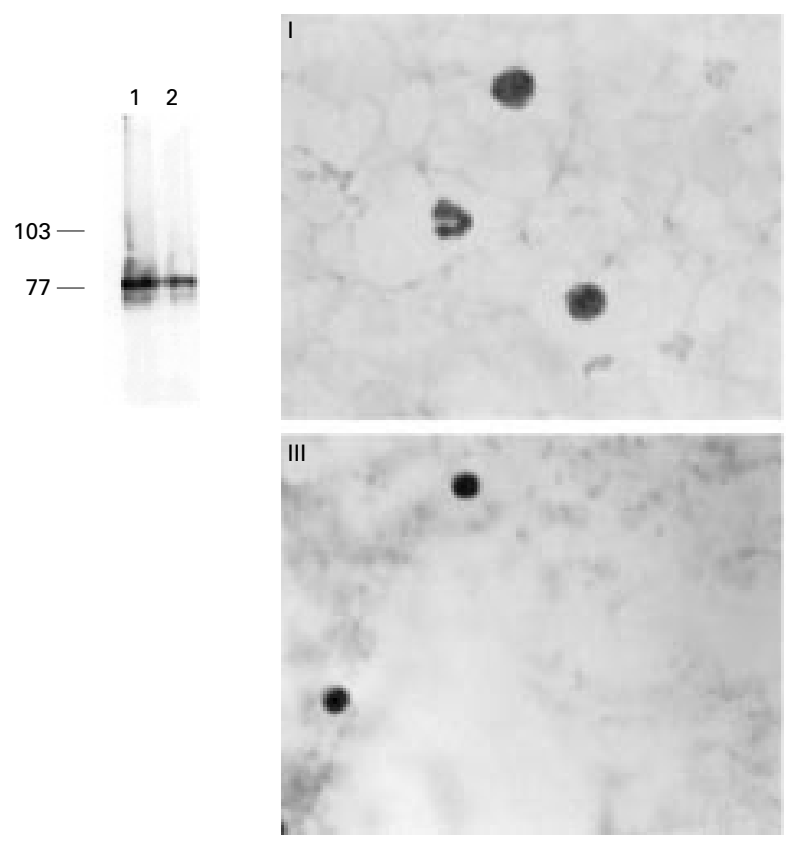

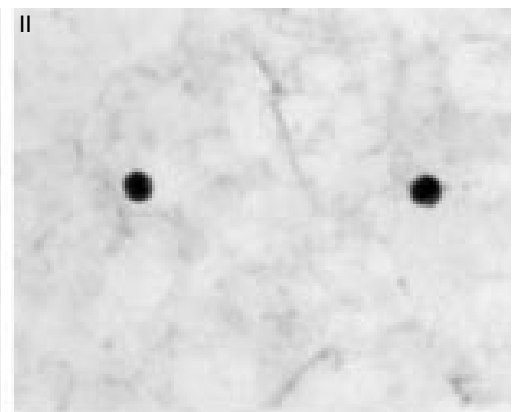

IV

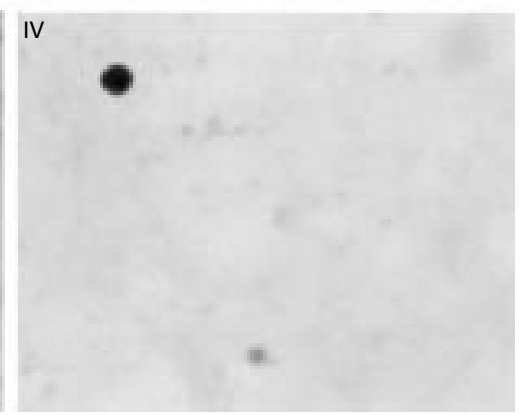

Figure 2 FMRP analysis. (A) Western blot analyses of FMRP expressed by the proband and a normal male are shown in lanes 1 and 2, respectively. Molecular weight standards (expressed in $\mathrm{kDa}$ ) are indicated on the left hand side of the panel. (B) Immunohistochemical staining of FMRP in lymphocytes of the proband (I), the proband's carrier mother (II), a negative control (III), and a positive control (IV). FMRP staining is seen in the cytoplasm, with the nuclei stained with Nuclear Fast Red.

from the background and from the secondary antibody controls as appropriate. Standard curves were generated using data from the purified proteins, which then allowed the quantitation of protein levels in the samples. Quantitation data was calculated as the molar ratio of FMRP:eIF4e. Purified FMRP was obtained from Keith Wilkinson and eIF4e was from Curt Hagedorn, both of Emory University.

In the case of western blot studies, total proteins were isolated from EBV transformed B lymphoblasts of the proband, as well as from a normal male control. The proteins were electrophoresed in a $7.5 \%$ non-denaturing polyacrylamide gel, and transferred to nitrocellulose and hybridised using $\mathrm{mAb} 1 \mathrm{C} 3$ as described above.

In the case of immunohistochemical staining of FMRP from blood smears, a modification of the method of Willemsen et $a l^{30}$ was used. Blood smears were counterstained with $\mathrm{Nu}-$ clear Fast Red and 100 lymphocytes were examined for each person, together with positive and negative control blood samples. Less than $42 \%$ of lymphocytes are FMRP positive in affected males, whereas for carrier females this figure is $83 \%$; the specificity of this assay is $100 \%$ for males and $41 \%$ for females. ${ }^{31}$

\section{Results}

Cytogenetic analysis of the proband's chromosomes indicated an apparently normal $46, \mathrm{XY}$ karyotype. Southern blot analysis showed a positively hybridising $2.8 \mathrm{~kb}$ DNA fragment, suggesting a normal sized CGG repeat length in the FMR-1 gene (fig 1A). PCR amplification of this locus using previously published primers FMRA and FMRB $^{32}$ yielded no product from the proband's genomic DNA. However, amplification products were obtained using primers FMRA and FMR2 (643 bp) and FMR1 and FMR2 (1 kb, fig 1B). The latter product was sequenced and showed a deletion of a 5 bp direct repeat, GAAGA, either immediately upstream, or encompassing the first base, of the ATG initiation codon of the FMR-1 gene (fig 1C, D). The mother of the proband was found to be heterozygous for this deletion event (data not shown). The deletion leaves the ATG codon unchanged and in phase with the remaining open reading frame of the $F M R-1$ gene.

FMRP quantitation, western blot analysis, and immunohistochemical studies were undertaken using the patient's lymphoblasts to determine the effect of the deletion event on translation initiation (fig 2). In order to assess the level of FMRP in the patient's lymphoblasts, quantitation studies were undertaken using the protein eIF4e as an internal control. The latter protein is the cap binding protein in eukaryotic translation initiation ${ }^{33}$ and is the rate limiting factor in translation initiation. ${ }^{34-36}$ FMRP levels were normalised with respect to eIF4e levels as a loading control. In seven cell lines from males with normal CGG allele lengths, the mean molar ratio of FMRP:eIF4e is 0.218 (standard deviation of 0.009). In the case of the cells from the proband, the molar ratio was 0.214 , and thus the level of FMRP is not reduced compared to normal cell lines. In the case of the western blot analysis, normal sized FMRP was detected (fig 2A). Immunohistochemical staining of lymphocytes from the proband and his carrier mother showed FMRP staining in $80 \%$ and $98 \%$ of 100 lymphocytes examined, respectively (fig $2 \mathrm{~B}$ ). 


\section{Discussion}

The proband reported here carries an apparent null allele with respect to the primer pair FMRA and FMRB, which are used routinely for amplifying the CGG repeat tract of the FMR-1 gene. This case suggests that caution should be exercised regarding predictive testing for fragile $\mathrm{X}$ syndrome that relies solely on PCR amplification of the FMR-1 gene using one primer pair only. This reliance has been suggested as a first level predictive screen for fragile $\mathrm{X}$ syndrome in the general population. ${ }^{37}$ The need for caution with respect to single PCR amplifications of trinucleotide repeats has also been described with regard to predictive testing for the Huntington's disease (HD) gene. $^{38}$ Our data underline the need for complementing PCR analysis with Southern blotting or, at minimum, PCR amplification of the CGG repeat region with two primer pairs.

Direct sequencing of amplification products using primers that map further upstream and downstream of FMRA and FMRB identified a 5 bp microdeletion near, or encompassing, the initiation codon of the FMR-1 gene. It appears that this deletion affects the annealing of the FMRB primer leading to inefficient amplification using this primer. The proband represents one of only a few cases that have been reported to have microdeletions in the FMR-1 gene..$^{23}$ In these other cases, which were found in subjects with fragile $\mathrm{X}$ syndrome, the microdeletions ranged from $116 \mathrm{bp}$ to $567 \mathrm{bp}$ and were located in the 5' UTR of the FMR-1 gene. The deletions were expected to lead to a lack of the FMR-1 gene product, which was confirmed in some patients. ${ }^{23}$ A mispairing model for the generation of a $486 \mathrm{bp}$ deletion was described by Schmucker et $a l,{ }^{24}$ which involved chi-like elements flanked by direct tandem repeats. In the case reported here, end joining, strand slippage, or indeed homologous recombination are possible molecular mechanisms that could account for the $5 \mathrm{bp}$ deletion event.

Changes in the sequence of DNA upstream of an initiation codon can dramatically influence translation efficiency. ${ }^{39}$ Fragile $\mathrm{X}$ males with a full mutation have complete absence of FMRP. However, in the case described here, FMRP was detected of apparently normal size and at normal levels in the lymphocytes of the proband.

This study leads to the suggestion that the proband does not have fragile $\mathrm{X}$ syndrome and that the $5 \mathrm{bp}$ deletion in this patient's FMR-1 gene is not causative of his phenotype. The FMRP detected in this patient appears to be qualitatively and quantitatively normal. Therefore, the comprehensive screening of genes implicated in disorders that are similar to fragile X syndrome may help resolve the cause of this patient's phenotype.

We acknowledge Dr Hugh Lees of Waikato Tauranga for bringing this case to our attention and the technical assistance of Jane Iber. We further acknowledge the financial assistance of Laboratory Services of Auckland Hospital for running expenses, and the University of Auckland Research Committee and the Lottery Grants Board of New Zealand for funding an Applied Biosystems Model 377 DNA Sequencer.

1 Warren ST, Nelson DL. Advances in molecular analysis of fragile X syndrome. FAMA 1994;271:536-42.
- We report here a case that was referred for testing for fragile $\mathrm{X}$ syndrome. The patient was found to carry an apparent null allele by routine clinical PCR, but with CGG repeats that fall within the normal range.

- DNA sequencing showed that the patient carried a microdeletion of a $5 \mathrm{bp}$ direct repeat immediately upstream, or encompassing, the translation initiation codon of the FMR-1 gene.

- Protein studies indicated that the patient expressed the protein product of the FMR-1 gene (FMRP), and that this expression was at near normal levels in the patient's lymphoblasts.

2 Turner G, Webb T, Wake S, Robinson H. Prevalence of fragile X syndrome. Am F Med Genet 1996;64:196-7.

3 Syrrou M, Georgiou I, Grigoriadou M, Petersen MB, Kitsiou S, Pagoulatos G, Patsalis PC. FRAXA and FRAXE prevalence in patients with nonspecific mental retardation in the Hellenic population. Genet Epidemiol 1998;15:103-9.

$4 \mathrm{Fu}$ YH, Kuhl DP, Pizzuti A, Pieretti M, Sutcliffe JS, Richards S, Verkerk AJ, Holden JJ, Fenwick RG Jr, Warren ST, Oostra BA, Nelson DL, Caskey CT. Variation of the CGG repeat at the fragile $X$ site results in genetic instability: resolution of the Sherman paradox. Cell 1991;67:1047-58.

5 Fragile $\mathrm{X}$ syndrome: diagnostic and carrier testing. Working Group of the Genetic Screening Subcommittee of the Clinical Practice Committee. American College of Medical Genetics. Am f Med Genet 1994;53:380-1.

6 Warren ST, Nelson DL. Trinucleotide repeat expansions in neurological disease. Curr Opin Neurobiol 1993;3:752-9.

7 Oberle I, Rousseau F, Heitz D, Kretz C, Devys D, Hanauer A, Boue J, Bertheas MF, Mandel JL. Instability of a 550 -base pair DNA segment and abnormal methylation in ragile X syndrome. Science 1991;252:1097-102.

8 Bell MV, Hirst MC, Nakahori Y, MacKinnon RN, Roche A, Flint TJ, Jacobs PA, Tommerup N, Tranebjaerg L, FrosterIskenius U, Kerr B, Turner G, Lindenbaum RH, Winter R, Pembrey M, Thibodeau S, Davies KE. Physical mapping across the fragile X: hypermethylation and clinical expression of the fragile X syndrome. Cell 1991;64:861-6.

9 Pieretti M, Zhang F, Fu YH, Warren ST, Oostra BA, Caskey CT, Nelson DL. Absence of expression of the FMR-1 gene in fragile X syndrome. Cell 1991;66:817-22.

10 Sutcliffe JS, Nelson DL, Zhang F, Pieretti M, Caskey CT, Saxe D, Warren ST. DNA methylation represses FMR-1 transcription in fragile X syndrome. Hum Mol Genet 1992; 1:397-400.

11 Feng Y, Zhang F, Lokey LK, Chastain JL, Lakkis L, Eberhart D, Warren ST. Translational suppression by trinucleotide repeat expansion at FMR1. Science 1995;268: 731-4.

12 De Boulle K, Verkerk AJ, Reyniers E, Vits L, Hendrickx J, Van Roy B, Van den Bos F, de Graaff E, Oostra BA, Willems PJ. A point mutation in the FMR-1 gene associated with fragile X mental retardation. Nat Genet 1993;3:31-5.

13 Lugenbeel KA, Peier AM, Carson NL, Chudley AE, Nelson DL. Intragenic loss of function mutations demonstrate the primary role of FMR1 in fragile X syndrome. Nat Genet 1995;10:483-5.

14 Gedeon AK, Baker E, Robinson H, Partington MW, Gross B, Manca A, Korn B, Poustka A, Yu S, Sutherland GR, Mulley JC. Fragile $\mathrm{X}$ syndrome without CCG amplification has an FMR1 deletion. Nat Genet 1992;1:341-4.

15 Tarleton J, Richie R, Schwartz C, Rao K, Aylesworth AS, Lachiewicz A. An extensive de novo deletion removing FMR1 in a patient with mental retardation and the fragile X syndrome phenotype. Hum Mol Genet 1993;2:1973-4.

16 Quan F, Grompe M, Jakobs P, Popovich BW. Spontaneous deletion in the FMR1 gene in a patient with fragile X syndrome and cherubism. Hum Mol Genet 1995;4:1681-4.

17 Quan F, Zonana J, Gunter K, Peterson KL, Magenis RE, Popovich BW. An atypical case of fragile X syndrome caused by a deletion that includes the FMR1 gene. $A m \mathcal{F}$ Hum Genet 1995;56:1042-51.

18 Wöhrle D, Kotzot D, Hirst MC, Manca A, Korn B, Schmidt A, Barbi G, Rott HD, Poustka A, Davies KE, Steinbach P. A microdeletion of less than $250 \mathrm{~kb}$, including the proximal part of the FMR-I gene and the fragile-X site, in a male with the clinical phenotype of fragile-X syndrome. Am $\mathcal{F}$ Hum Genet 1992;51:299-306.

19 Gu Y, Lugenbeel KA, Vockley JG, Grody WW, Nelson DL. A de novo deletion in FMR1 in a patient with developmental delay. Hum Mol Genet 1994;3:1705-6.

20 Meijer H, de Graaff E, Merckx DM, Jongbloed RJ, de DieSmulders CE, Engelen JJ, Fryns JP, Curfs PM, Oostra BA. A deletion of $1.6 \mathrm{~kb}$ proximal to the CGG repeat of the FMR1 gene causes the clinical phenotype of the fragile $\mathrm{X}$ syndrome. Hum Mol Genet 1994;3: 615-20. 
21 Trottier Y, Imbert G, Poustka A, Fryns JP, Mandel JL. Male with typical fragile $\mathrm{X}$ phenotype is deleted for part of the FMR1 gene and for about $100 \mathrm{~kb}$ of upstream region. $\mathrm{Am}$ 7 Med Genet 1994;51:454-7.

22 Hirst M, Grewal P, Flannery A, Slatter R, Maher E, Barton D, Fryns JP, Davies K. Two new cases of FMR1 deletion associated with mental impairment. Am f Hum Genet 1995;56:67-74

23 De Graaff E, De Vries BB, Willemsen R, van Hemel JO, Mohkamsing S, Oostra BA, van den Ouweland AM. The fragile $\mathrm{X}$ phenotype in a mosaic male with a deletion showing expression of the FMR 1 protein in $28 \%$ of the cells. $A m$ 7 Med Genet 1996;64:302-8.

24 Schmucker B, Ballhausen WG, Pfeiffer RA. Mosaicism of a microdeletion of $486 \mathrm{bp}$ involving the CGG repeat of the FMR1 gene due to misalignment of GTT tandem repeats at chi-like elements flanking both breakpoints and a full mutation. Hum Genet 1996;98:409-14.

25 Sutherland GR. Heritable fragile sites on human chromosomes. II. Distribution, phenotypic effects, and cytogenetsomes. II. Distribution, phenotypic effect
ics. Am f Hum Genet 1979;31:136-48.

26 Mila M, Castellvi-Bel S, Gine R, Vazquez C, Badenas C, Sanchez A, Estivill X. A female compound heterozygote (pre- and full mutation) for the CGG FMR1 expansion Hum Genet 1996;98:419-21.

27 Brown V, Small K, Lakkis L, Feng Y, Gunter C, Wilkinson KD, Warren ST. Purified recombinant Fmrp exhibits selective RNA binding as an intrinsic property of the fragile X mental retardation protein. I Biol Chem 1998;273: 15521-7.

28 Hagedorn CH, Spivak-Kroizman T, Friedland DE, Goss DJ, Xie Y. Expression of functional eIF4e human: purification, detailed characterization, and its use in isolating eIF-4e binding proteins. Protein Express Purif 1997;9:5360.

29 Devys D, Lutz Y, Rouyer N, Bellocq JP, Mandel JL. The FMR1 protein is cytoplasmic, most abundant in neurons and appears normal in carriers of a fragile $\mathrm{X}$ premutation. Nat Genet 1993;4:335-40
30 Willemsen R, Mohkamsing S, de Vries B, Devys D, van den Ouweland A, Mandel JL, Galjaard H, Oostra B. Rapid antibody test for fragile $\mathrm{X}$ syndrome. Lancet 1995;345: $1147-8$

31 Willemsen R, Smits A, Mohkamsing S, van Beerendonk H, de Haan A, de Vries B, van den Ouweland A, Sistermans E, Galjaard H, Oostra BA. Rapid antibody test for diagnosing fragile X syndrome: a validation of the technique. Hum Genet 1997;99:308-11.

32 Snow K, Doud LK, Hagerman R, Pergolizzi RG, Erster SH, Thibodeau SN. Analysis of a CGG sequence at the FMR-1 locus in fragile $\mathrm{X}$ families and in the general population. Am f Hum Genet 1993;53:1217-28.

33 Hiremath LS, Webb NR, Rhoads RE. Immunological detection of the messenger RNA cap-binding protein. $f$ Biol Chem 1985;260:7843-9.

34 Duncan R, Hershey JWB. Identification and quantification of levels of protein synthesis initiation factors in crude HeLa cell lysates by two-dimensional polyacrylamide gel electrophoresis. F Biol Chem 1983;258:7228-35.

35 Duncan R, Milburn SC, Hershey JWB. Regulated phosphorylation and low abundance of HeLa cell initiation factor eIF-4F suggests a role in translational control. $\mathcal{F}$ Biol Chem 1987;262:380-8

36 Wei CL, MacMillan SE, Hershey JWB. Protein synthesis initiation factor eIF-1A is a moderately abundant RNAinitiation factor eIF-1A is a moderately abundant
binding protein. $\mathcal{F}$ Biol Chem 1995;270:5764-71.

37 Erster SH, Brown WT, Goonewardena P, Dobkin CS, Jenkins EC, Pergolizzi RG. Polymerase chain reaction analysis of fragile X mutations. Hum Genet 1992;90:55-61.

38 Williams LC, Hegde MR, Nagappan R, Bullock J, Faull RLM, Winship I, Snow K, Love DR. Null alleles at the Huntington disease locus: implications for diagnostics, and CAG repeat instability. Genet Testing 2000;4:55-60.

39 Kozak M. Recognition of AUG and alternative initiator codons is augmented by $\mathrm{G}$ in position +4 but is not generally affected by the nucleotides in positions +5 and +6 . EMBO f 1997;16:2482-92.

\section{Non-invasive evaluation of arterial involvement in patients affected with Fabry disease}

Pierre Boutouyrie, Stéphane Laurent, Brigitte Laloux, Olivier Lidove, Jean-Pierre Grunfeld, Dominique P Germain

EDITOR-Fabry disease (FD) (OMIM $301500)$ is an $\mathrm{X}$ linked recessive disease resulting from deficiency of the lysosomal hydrolase $\alpha$-galactosidase A. ${ }^{1}$ The enzymatic defect leads to the widespread deposition of uncleaved neutral glycosphingolipids in the plasma and lysosomes, especially in vascular endothelial and smooth muscle cells. Initial clinical signs include skin lesions (angiokeratoma), excruciating acral pain, and benign corneal opacities. Progressive glycosphingolipid deposition in the microvasculature of hemizygous males subsequently leads to failure of target organs and to ischaemic complications involving the kidneys, heart, and brain. ${ }^{23}$ Much interest is currently shown in emerging therapies for FD and recent studies have reported that genetic engineering has removed many of the obstacles to the clinical use of enzyme replacement and that infusions of purified $\alpha$-galactosidase A are safe and biochemically active. ${ }^{45}$ However, clinical and laboratory indicators of benefit are lacking, given the slow course of the disease. This emphasises the need for non-invasive surrogate endpoints to delineate target organ damage and to monitor the efficacy of enzyme replacement therapies.

\section{Methods and results}

In the present study, we determined intimamedia thickness (IMT) at the site of the radial artery, a distal, muscular, medium sized artery, in a cohort of 21 hemizygous male FD patients, with a mean age of 32 years (SD 13, range 13-56 years), compared with 21 age and sex matched normal controls. All patients were diagnosed with FD by the presence of both clinical signs and a markedly decreased $\alpha$-galactosidase $\mathrm{A}$ activity in leucocytes $(<4$ $\mathrm{nmol} / \mathrm{h} / \mathrm{mg}$ protein, normal values $25-55 \mathrm{nmol} /$ $\mathrm{h} / \mathrm{mg}$ protein). No patient had end stage renal disease. Measurements of the radial artery parameters were obtained with a high precision echotracking device (NIUS 02, SMH, Bienne, Switzerland) as previously described. ${ }^{6}$ Briefly, the radiofrequency signal was visualised and the peaks corresponding to the blood-intima and media-adventitia interface were electronically tagged and followed over several cardiac cycles. Internal diameter and wall thickness were then measured with a precision of about $10 \mu \mathrm{m}$. Four to six measurements were averaged. ${ }^{67}$ Radial artery IMT was measured 2 $\mathrm{cm}$ upstream from the wrist.

Compared to controls, FD patients had considerably higher IMT values at the site of the radial artery (fig 1). IMT was twice as high in 


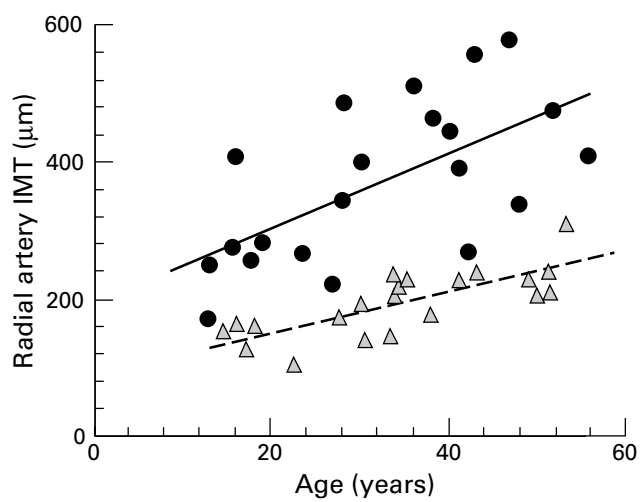

Figure 1 Correlation between radial artery intima-media thickness and age in patients with Fabry disease (circles) and in control subjects (triangles). Correlations are significant $(p<0.001)$ in both populations and slopes differ significantly (59 (SD 14) v 25 (SD 4) $\mu \mathrm{m}$ per 10 years, $p<0.001)$.

FD patients than in controls, even after adjustment for body surface area, age, and mean blood pressure $(p<0.001)$. Radial artery IMT increased significantly with age in each group. However the slope was 2.3-fold higher in FD patients than in controls $(\mathrm{p}<0.001)$ (fig 1$)$.

\section{Discussion}

In the present study, we describe evidence of a major, accelerated hypertrophy of the wall of a medium sized artery in a cohort of patients with FD. The magnitude of the difference in radial artery IMT was very large, with virtually no overlap between FD patients and controls. With age, the radial artery wall thickening was 2.3-fold faster in FD patients than in controls. The high definition echotracking system used in the present study has been previously validated in large subsets of patients with various diseases, and its accuracy and reproducibility are well accepted. ${ }^{6}$

The most commonly proposed explanation for the pathogenesis of cardiovascular lesions in FD patients is the slow deposition of uncleaved neutral glycosphingolipids within the arterial and cardiac tissues. However, the hypothesis of

A Control subject

Bidimensional scan

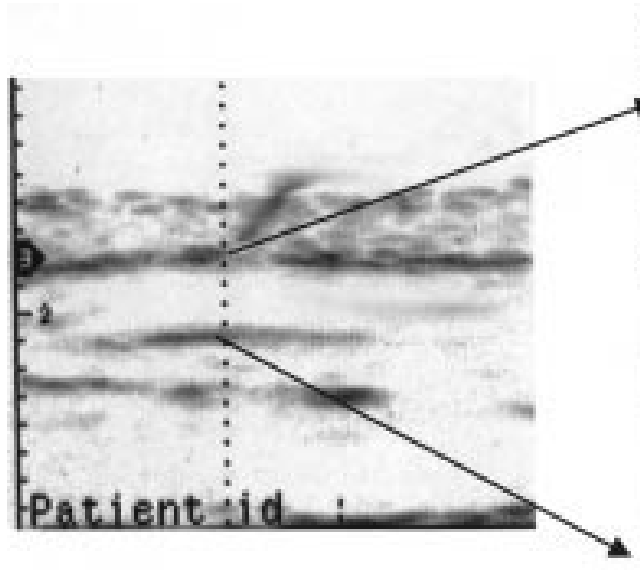

B Fabry patient
RF signal

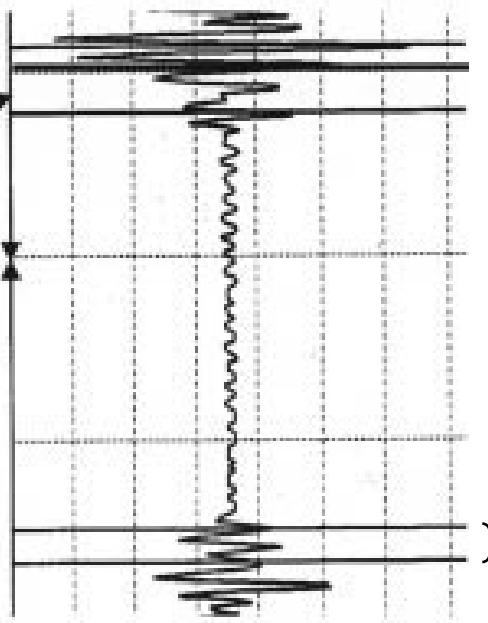

Anterior wall

Lumen

Posterior wall

RF signal

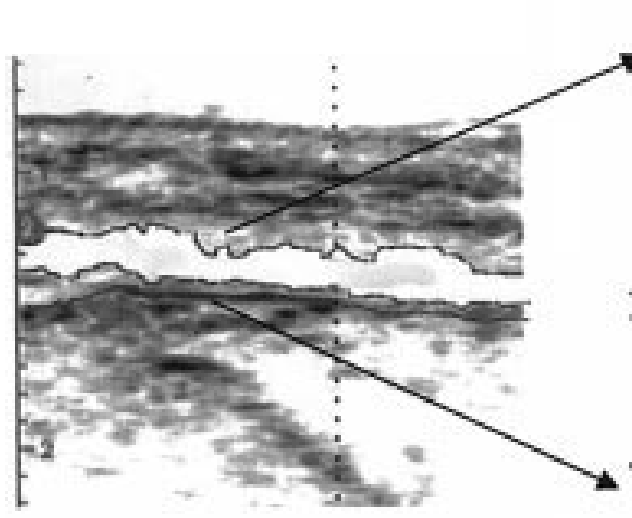

Anterior wall

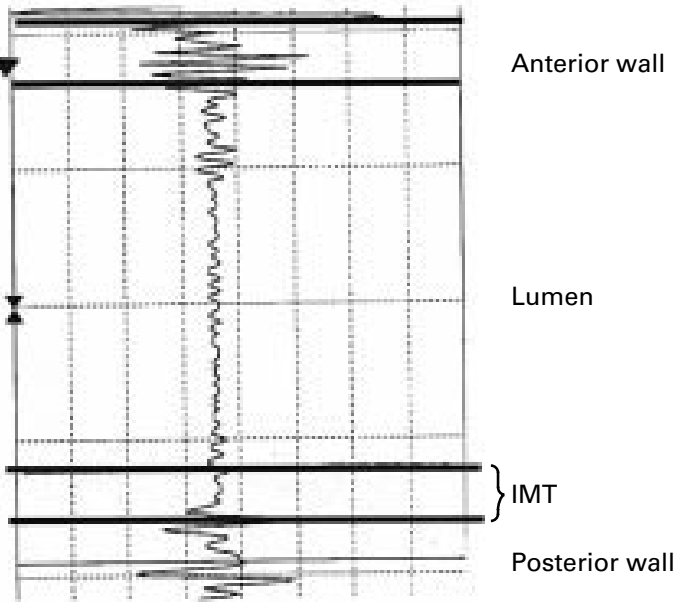

Figure 2 Bidimensional scans and radiofrequency signals $(R F)$ of the right radial artery from a control $(A)$ and a patient with Fabry disease (B). Lumen and posterior wall contours have been emphasised. Intima-media thickness (IMT) was measured from the distance between the RF peaks corresponding to the blood-intima and media-adventitia interfaces. Note the irregularity and the prominent thickening of the arterial wall in the Fabry patient. 
a sole lysosomal accumulation of sphingolipids is somewhat simplistic since in the most advanced reported cases of left ventricle hypertrophy in FD patients, the amount of uncleaved glycosphingolipids found in the cardiac tissue did not exceed $1.6 \%$ of tissue weight (10-20 $\mathrm{mg} / \mathrm{g}$ wet weight). ${ }^{8}$ Other mechanisms are thus probably involved. First, although accumulation of globotriaosylceramide is the main mechanism in FD, the metabolism of other glycosphingolipids may also be disregulated. ${ }^{9}$ Among them, lactosylceramide, which mimics the biological function of cytokines, growth factors, and stress signalling molecules ${ }^{1011}$ and accumulates in vascular tissues of FD patients, ${ }^{89}$ could act as a second messenger and potentiate the hypertrophy of the arterial wall. Second, the smaller internal diameter of the radial artery in FD patients may be the result not only of wall hypertrophy encroaching the lumen (fig 2), but also endothelial dysfunction. Deposition of glycosphingolipids occurs predominantly in the lysosomes of endothelial and smooth muscle cells, with consequent cellular dysfunction. ${ }^{3}$ An altered endothelium dependent relaxation of arterial smooth muscle could occur at the site of the radial artery or downstream, in arterioles, influencing the tonic flow dependent vasodilatation. The mechanism of flow dilatation is known to occur physiologically at the site of the radial and brachial arteries, ${ }^{12}$ and has been related to changes in basal and stimulated nitric oxide (NO) release. ${ }^{12}$ Finally, both in the media and intima, smooth muscle cells with glycosphingolipid inclusions secrete important quantities of extracellular matrix, notably elastic fibres. ${ }^{8}$ Proliferation of smooth muscle cells and extracellular matrix deposition may thus contribute to the hypertrophy of the radial artery observed in FD patients.

In conclusion, this study presents the first non-invasive demonstration of a major increase in arterial wall thickness at the site of the radial artery in a cohort of patients with confirmed FD. The assessment of the involvement of the large arteries, through non-invasive procedures, could prove useful in monitoring new therapies for FD in providing an intermediate phenotype or a surrogate marker. However, the prognostic significance of the radial artery wall hypertrophy and its ability to regress with emerging treatments, such us enzyme replacement $^{451314}$ or gene therapy, ${ }^{15}$ remains to be determined during follow up studies.

This study received financial support from the Institut National de la Santé et de la Recherche Médicale (INSERM) and from Vaincre les Maladies Lysosomales (VML).

1 Brady RO, Gal AE, Bradley RM, Martensson R, Warshaw AL, Laster L. Enzymatic defect in Fabry's disease: ceramide-trihexosidase deficiency. $N$ Engl $\mathcal{f}$ Med 1967;276:1163-7

2 Desnick RJ, Ioannou YA, Eng CM. $\alpha$-galactosidase A deficiency: Fabry disease. In: Scriver CR, Beaudet AL, Sly WS, Valle D, Kinzler KE, Vogelstein B, eds. The metabolic and molecular bases of inherited diseases. 8th ed. New York: McGraw-Hill, 2001:3733-74.

3 Germain DP. Fabry disease. Clinical and genetic aspects. Therapeutic perspectives. Rev Med Intern 2000;21:1086103.

4 Schiffmann R, Murray GJ, Treco D, Daniel P, Sellos-Moura M, Myers M, Quirk JM, Zirzow GC, Borowski M, Loveday K, Anderson T, Gillespie F, Oliver KL, Jeffries NO, Doo E, Kiang TJ, Kreps C, Gunter K, Frei K, Crutchfield K, Liang TJ, Kreps C, Gunter K, Frei K, Crutchfield K,
Selden RF, Brady RO. Infusion of alpha-galactosidase A Selden RF, Brady RO. Infusion of alpha-galactosidase A
reduces tissue globotriaosylceramide storage in patients reduces tissue globotriaosylceramide storage in patients 70 .

5 Eng CM, Cochat P, Wilcox WR, Germain DP, Lee P, Waldek S, Caplan L, Heymans H, Braakman T, Fitzpatrick MA, Huertas P, O'Callaghan MW, Richards S, Tandon PK, Desnick RJ. Enzyme replacement therapy in Fabry disease: results of a placebo-controlled phase 3 trial. $A m \mathcal{F}$ Hum Genet 2000;67:A134.

6 Boutouyrie P, Bussy C, Lacolley P, Girerd X, Laloux B, Laurent $S$. Association between local pulse pressure, mean blood pressure and arterial remodeling. Circulation 1999; 100:1387-93.

7 Girerd X, Mourad JJ, Acar C, Heudes D, Chiche S, Bruneval P, Mignot JP, Billaud E, Safar M, Laurent S. Noninvasive measurement of medium-sized artery intimamedia thickness in humans: in vitro validation. $\mathcal{F}$ Vasc Res 1994;31:114-20.

8 Elleder M, Bradova V, Smid F, Budesinsky M, Harzer K, Kustermann-Kuhn B, Ledvinova J, Belohlavek, Kral V, Dorazilova V. Cardiocyte storage and hypertrophy as a sole manifestation of Fabry's disease. Report on a case simulating hypertrophic non-obstructive cardiomyopathy. Virchows Arch A Pathol Anat Histopathol 1990;417:449-55.

9 Desnick RJ, Blieden LC, Sharp HL, Hofshire PJ, Moller JH. Cardiac and valvular anomalies in Fabry disease. Clinical, morphologic and biochemical studies. Circulation 1976;54: 818-25.

10 Chatterjee S. Sphingolipids in atherosclerosis and vascular biology. Arterioscler Thromb Vasc Biol 1998;18:1523-33.

11 Kolter T, Sandhoff K. Recent advances in the biochemistry of sphingolipidoses. Brain Pathol 1998;8:79-100.

12 Joannides R, Richard V, Haefeli WE, Linder L, Luscher TF, Thuillez C. Role of basal and stimulated release of nitric oxide in the regulation or radial artery caliber in humans. oxide in the regulation or radial

13 Ioannou Y, Zeidner K, Friedman B, Desnick R. Fabry disease: enzyme replacement therapy in $\alpha$-galactosidase A disease: enzyme replacement therapy in $\alpha$-galacto
deficient mice. Am f Hum Genet 2000;68:14-25.

14 Eng CM, Guffon N, Wilcox WR, Germain DP, Lee P, Waldek S, Caplan L, Linthorst GE, Desnick RJ. A multicenter, randomized, double-blind, placebo-controlled study of the safety and efficacy of recombinant human $\alpha$-galactosidase A replacement therapy in Fabry disease. $N$ Engl f Med (in press).

15 Ziegler RJ, Yew NS, Li C, Cherry M, Berthelette P, Romanczuk H, Ioannou YA, Zeidner KM, Desnick RJ, Cheng SH. Correction of enzymatic and lysosomal storage defects in Fabry mice by adenovirus-mediated gene transfer. Hum Gene Ther 1999;10:1667-82. 


\section{Variation of iron loading expression in C282Y homozygous haemochromatosis probands and sib pairs}

Catherine Mura, Gérald Le Gac, Virginie Scotet, Odile Raguenes, Anne-Yvonne Mercier, Claude Férec

EDITOR-Hereditary haemochromatosis $(\mathrm{HH})$, a common autosomal recessive disease of iron metabolism, is more prevalent among populations of northern Europe with an affected rate of 1 in 200 to 400 and a carrier frequency of around 1 in $10 .^{12}$ The disease is characterised by progressive iron overload, and the clinical onset usually appears after middle age. The phenotypic manifestations of $\mathrm{HH}$ are variable, and the severity of the disease is related to the iron loading; the most common symptoms of iron overload are fatigue, lethargy, arthropathy, and skin pigmentation, often along with more serious organ damage including cirrhosis, diabetes mellitus, myocardiopathy, and endocrine dysfunction. The assessment of iron loading is currently based on the levels of biochemical iron markers such as transferrin saturation percentage, serum ferritin, and serum iron concentrations. However, the diagnosis of haemochromatosis can now be confirmed using direct HFE mutation testing. The prognosis depends on early diagnosis and therapeutic venesections. Thus, population screening would allow early diagnosis during the asymptomatic phase and prophylactic treatment by repeated venesection to prevent the irreversible damage of iron overload, ${ }^{3}$ but predictive diagnosis requires a well established phenotype-genotype correlation.

The identification of the haemochromatosis gene, ${ }^{4}$ now referred to as $H F E,{ }^{5}$ enables the performance of direct genetic testing for diagnosis. The role of the HFE protein in iron metabolism has not yet been clearly established, but it seems that the complex of HFE with $\beta 2$-microglobulin interacts with the transferrin receptor (TfR) on the cell surface, which decreases the affinity of TfR for transferrin. ${ }^{6-9}$ Some mutations characterised in the HFE gene and leading to a functional defect have been correlated with $\mathrm{HH}$. Two missense mutations, $845 \mathrm{G} \rightarrow \mathrm{A}(\mathrm{C} 282 \mathrm{Y})$ accounting for $80-90 \%$ of $\mathrm{HH}$ chromosomes, ${ }^{40-13}$ and $187 \mathrm{C} \rightarrow \mathrm{G}$, (H63D) representing $40-70 \%$ of non-C282Y $\mathrm{HH}$ chromosomes, ${ }^{4-12}{ }^{2-15}$ leading to the absence and decrease of HFE activity, respectively, have been described. ${ }^{16}{ }^{17}$ Another variant, $193 \mathrm{~A} \rightarrow \mathrm{T}$, leading to the missense substitution $\mathrm{S} 65 \mathrm{C}$, has been reported to be increased in $\mathrm{HH}$ chromosomes, accounting for $7.2 \%$ of $\mathrm{HH}$ chromosomes, neither $845 \mathrm{~A}(\mathrm{C} 282 \mathrm{Y})$ nor $187 \mathrm{G}$ (H63D)..$^{18}$

The considerable heterogeneity of iron loading observed in $\mathrm{HH}$ patients has been correlated with their genotype. Several studies have confirmed that $\mathrm{HH}$ patients homozygous for the C282Y mutation are associated with a more severe form of the disease than those carrying other genotypes (H63D/H63D, C282Y/H63D, C282Y/S65C). ${ }^{12}{ }^{13} 19$ Phenotypegenotype correlation studies have shown discrepancies. Some reports have mentioned patients diagnosed with haemochromatosis who did not carry known HFE mutations on both chromosomes, accounting for up to $21 \%$ of the $\mathrm{HH}$ population. ${ }^{412}{ }^{13}$ Thus, the aetiology of the iron loading in these patients remains unclear. Non-HFE related patient cases may have been included in these $\mathrm{HH}$ subjects because of misdiagnosis owing to secondary iron overload or atypical juvenile haemochromatosis linked to chromosome $1 \mathrm{q}^{20-21}$; this point still needs to be clarified. In addition, despite the prominent role of the C282Y mutation in $\mathrm{HH}$, population screening indicates that $17.6 \%$ of homozygotes for $\mathrm{C} 282 \mathrm{Y}$ were asymptomatic patients. ${ }^{22}$ Thus, C282Y penetrance confronts one with a problem and requires more investigation.

In the present study, we assessed the biochemical expression of iron loading in $H F E$ C282Y homozygotes. We thus examined the parameters indicative of iron loading in a series of probands homozygous for the C282Y mutation. Then we conducted a family case study of $H F E$ identical sibs enrolled because one of them had HH. The whole study showed a variable biochemical expression of iron overload related to the patients' age and sex, which was not correlated in subjects with an identical inherited genotype at the $H F E$ locus.

\section{Patients and methods}

SUBJECTS

A series of 545 unrelated probands, all homozygous for C282Y, showing various symptoms of clinical haemochromatosis and referred from clinicians to our blood centre for treatment by venesection, was included in this study. Before treatment the diagnosis was confirmed by their iron status markers, and all of them showed at least two of the following criteria: (1) transferrin saturation higher than $60 \%$ in males and $50 \%$ in females, (2) serum ferritin concentration exceeding $400 \mu \mathrm{g} / 1$ in males and $300 \mu \mathrm{g} / 1$ in females, and (3) serum iron above $20 \mu \mathrm{mol} / 1$. These iron status markers were measured by standard techniques.

\section{SIB PAIR STUDY}

As part of genetic counselling a family study was conducted. Partners and sibs of C282Y $\mathrm{HH}$ probands were screened for $H F E$ mutations and biochemical iron markers. The study 
Table 1 Iron status in 545 probands homozygous for the C282Y mutation

\begin{tabular}{|c|c|c|c|c|c|}
\hline Sex & Age & No & $\begin{array}{l}\text { Transferrin } \\
\text { saturation (\%) }\end{array}$ & $\begin{array}{l}\text { Serum ferritin } \\
(\mu g / l)\end{array}$ & $\begin{array}{l}\text { Serum iron } \\
(\mu \mathrm{mol} / \mathrm{l})\end{array}$ \\
\hline $\mathrm{F}$ & $<30$ & 11 & $\begin{array}{l}68(11.8) \\
{[55-82]}\end{array}$ & $\begin{array}{l}262(104) \\
{[108-398]}\end{array}$ & $\begin{array}{l}37(5.6) \\
{[28-42]}\end{array}$ \\
\hline$M$ & $<30$ & 22 & $\begin{array}{l}79.6(16.7) \\
{[51-98]} \\
\text { NS }\end{array}$ & $\begin{array}{l}598(506) \\
{[83-2000]} \\
\text { NS }\end{array}$ & $\begin{array}{l}38.4(8.8) \\
{[21-49]} \\
\text { NS }\end{array}$ \\
\hline $\mathrm{F}$ & $<40$ & 30 & $\begin{array}{l}79(14.7) \\
{[57-99]}\end{array}$ & $\begin{array}{l}663(944) \\
{[69-4000]}\end{array}$ & $\begin{array}{l}37(11.3) \\
{[14-62]}\end{array}$ \\
\hline$M$ & $<40$ & 105 & $\begin{array}{l}78.2(15.5) \\
{[34-100]} \\
\text { NS }\end{array}$ & $\begin{array}{l}1341(1078) \\
{[240-4800]} \\
p=0.02\end{array}$ & $\begin{array}{l}38.8(7.8) \\
{[22-69]} \\
\text { NS }\end{array}$ \\
\hline $\mathrm{F}$ & $<50$ & 50 & $\begin{array}{l}76.6(14.6) \\
{[54-95]}\end{array}$ & $\begin{array}{l}588(764) \\
{[36-3300]}\end{array}$ & $\begin{array}{l}33.2(6.6) \\
{[22-53]}\end{array}$ \\
\hline M & $<50$ & 117 & $\begin{array}{l}82.5(12.1) \\
{[44-100]} \\
\mathrm{p}=0.05\end{array}$ & $\begin{array}{l}1822(1672) \\
{[95-8890]} \\
p=0.0003\end{array}$ & $\begin{array}{l}38.4(6.3) \\
{[22-51]} \\
p=0.055\end{array}$ \\
\hline $\mathrm{F}$ & $<60$ & 52 & $\begin{array}{l}70(16.9) \\
{[27-96]}\end{array}$ & $\begin{array}{l}847(657) \\
{[77-2500]}\end{array}$ & $\begin{array}{l}31.8(6.4) \\
{[22-48]}\end{array}$ \\
\hline M & $<60$ & 71 & $\begin{array}{l}81.8(12) \\
{[47-97]} \\
\mathrm{p}=0.001\end{array}$ & $\begin{array}{l}2133(1601) \\
{[450-5368]} \\
p=7.10^{-6}\end{array}$ & $\begin{array}{l}44.7(25.2) \\
{[27-57]} \\
p=0.01\end{array}$ \\
\hline $\mathrm{F}$ & $>60$ & 54 & $\begin{array}{l}75.8(18.4) \\
{[37-98]}\end{array}$ & $\begin{array}{l}1649(1525) \\
{[195-6680]}\end{array}$ & $\begin{array}{l}36.3(8.4) \\
{[14-55]}\end{array}$ \\
\hline$M$ & $>60$ & 33 & $\begin{array}{l}79.6(18) \\
{[37-95]} \\
\text { NS }\end{array}$ & $\begin{array}{l}2349(2059) \\
{[215-8800]} \\
p=0.033\end{array}$ & $\begin{array}{l}38.8(6) \\
{[28-49]} \\
\text { NS }\end{array}$ \\
\hline
\end{tabular}

Transferrin saturation, serum ferritin, and serum iron values are expressed as means (SD) and range (NS = not significant).

group consisted of 53 subjects from 24 unrelated $\mathrm{HH}$ families in whom at least one sib had exhibited symptoms and an increased total body iron loading, indicative of $\mathrm{HH}$. This allowed the examination of 18 same sex sib pairs, homozygous for C282Y, and composed of 13 male pairs and five female pairs; eight others were opposite sex pairs. At the time of the biochemical diagnosis, all these sibs were 32 to 64 years old. The mean difference in age within a set of sibs was 5.6 years.

HFE MUTATION ANALYSIS

DNA was extracted from peripheral blood leucocytes. C282Y, H63Ds, and S65C substitutions were analysed as previously described. ${ }^{18}$

\section{STATISTICAL ANALYSIS}

Measurements of transferrin saturation, serum ferritin, and serum iron are expressed as means (SD) and range is indicated. Comparisons between groups of subjects were made with Student's $t$ test and correlation between iron parameters was assessed. The relationship between the iron parameters and the age of patients was studied separately in males and females using linear regression analysis.

\section{Results}

A total of 545 unrelated subjects including 197 females and 348 males, all diagnosed with $\mathrm{HH}$ and homozygous for the C282Y mutation, were studied. Thus, the male to female sex ratio was $1.7: 1$ showing a reduced penetrance of the C282Y mutation in females compared to males. The difference in age at onset was recorded according to the sex of probands. The mean age was 44.1 (SD 10.9) and 49.8 (SD 12.5) in males and females, respectively. The difference in mean age at onset calculated between the males and the females using Student's $t$ test was significant $(\mathrm{t}=4.57, \mathrm{p}=3.3 \times$ $10^{-6}$ ) showing that, at onset, females were significantly older than males. Approximately

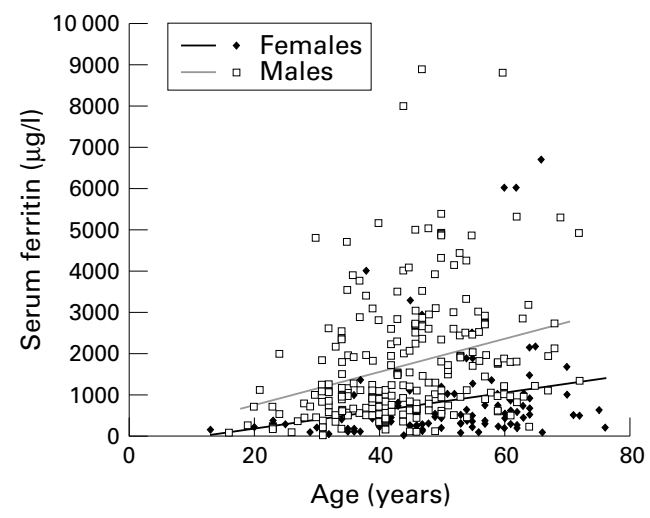

Figure 1 Distribution and correlation of serum ferritin concentration in 348 males $(r=0.29)$ and 197 females $(r=0.23)$ according to age. The equation of the fitted regression line was $Y=39.9 X-43.4$ in males (light line) and $Y=21.1 X-217.2$ in females (dark line).

$70 \%$ of the males were diagnosed with $\mathrm{HH}$ before the age of 50 , whereas only $48.6 \%$ of females were; $90 \%$ of the males and $76.5 \%$ of the females were diagnosed with $\mathrm{HH}$ before the age of 60 (table 1). These results show that the biochemical expression of haemochromatosis strongly depended on both sex and age in $\mathrm{C} 282 \mathrm{Y}$ homozygotes. Iron marker values ranged between normal and significantly increased compared with control values and regardless of the proband's sex and age. However, transferrin saturation, serum ferritin, and serum iron values as a whole were significantly higher in males than in females $\left(\mathrm{p}=1.2 \times 10^{-3}\right.$, $6.7 \times 10^{-8}, 9 \times 10^{-3}$, respectively).

According to the age range, above 30 years old serum ferritin and serum iron concentrations were significantly higher in males than in females; transferrin saturation was significantly increased with age only after 40 years in males compared with females (table 1). A correlation analysis showed that, whereas transferrin saturation and serum iron remained stable with age in both sexes, there was a progressive increase of serum ferritin concentration with age in males ( $r=0.29)$ and females ( $r=0.23$ ) (fig 1); it increased from 262 to $1355 \mu \mathrm{g} / \mathrm{l}$ in females and from 598 to $2349 \mu \mathrm{g} / 1$ in males aged from 30 to over 60 years of age. The linear regression analysis indicated a significant mean annual progression of serum ferritin of $39.9 \mu \mathrm{g} / \mathrm{l}$ $\left(\mathrm{p}<10^{-3}\right)$ in males and $\left.21.1 \mu \mathrm{g} / 1 \quad \mathrm{p}=10^{-2}\right)$ in females.

The biochemical data of families were reviewed following the discovery of one sib pair $H F E$ identical by descent, in which one sib exhibited total body iron overload and was clinically diagnosed as $\mathrm{HH}$. Sex matched sibs, homozygous for the C282Y mutation, were reviewed to determine the degree of iron loading in the other sib through transferrin saturation percentage and serum ferritin and serum iron concentrations. Opposite sex sibs were not compared because iron overload is known to be higher in male subjects compared to females. Therefore, $18 \mathrm{C} 282 \mathrm{Y}$ homozygous same sex sib pairs were examined; this showed that transferrin saturation ranged between 39 and $98 \%$, serum ferritin between 159 and 4900 $\mu \mathrm{g} / \mathrm{l}$, and serum iron from 12.5 to $48 \mu \mathrm{mol} / 1$. 
Table 2 Comparison of 18 same sex sib pairs homozygous for the C282Y mutation

\begin{tabular}{llll}
\hline & $\begin{array}{l}\text { Transferrin } \\
\text { saturation }(\%)\end{array}$ & $\begin{array}{l}\text { Serum ferritin } \\
(\mu \mathrm{g} / \mathrm{l})\end{array}$ & $\begin{array}{l}\text { Serum iron } \\
(\mu \mathrm{mol} / \mathrm{l})\end{array}$ \\
\hline Correlation & $\mathrm{r}=0.47$ & $\mathrm{r}=0.10$ & $\mathrm{r}=0.23$ \\
& $\mathrm{p}=0.07$ & $\mathrm{NS}$ & $\mathrm{NS}$ \\
Mean difference & $14[0-35]$ & $1026[90-4243]$ & $7.5[0-20]$ \\
& $\mathrm{t}=5.1$ & $\mathrm{t}=3.12$ & $\mathrm{t}=6.1$ \\
& $\mathrm{p}=0.00017$ & $\mathrm{p}=0.0065$ & $\mathrm{p}=0.00002$ \\
\hline
\end{tabular}

Transferrin saturation, serum ferritin, and serum iron means in probands were $79.4 \%$ (SD 13), $1382 \mu \mathrm{g} / 1$ (SD 1348), $39.5 \mu \mathrm{mol} / 1$ (SD 6.4 ), respectively, and in sib cases $74.2 \%$ (SD 19), $1069 \mu \mathrm{g} / \mathrm{l}$ (SD 1166), and $38.1 \mu \mathrm{mol} / 1$ (SD 8.1 ), respectively; these results were not significantly different. The concordance of these parameters between sib pairs was also assessed. There was no correlation of serum ferritin or serum iron levels between the $\mathrm{HH}$ diagnosed sibs and other sibs, while transferrin saturation level tended to be correlated, but remained non-significant $(p=0.07)$; the mean differences in transferrin saturation, serum ferritin, and serum iron values in sib pairs were all significant (table 2). In addition, no significant correlation was found between the oldest and the youngest sibs for the three iron markers when all same sex pairs were considered, indicating that, in this case, the lack of correlation was not related to the age of the subjects. This intrafamilial study showed a variable level of iron overload for subjects with $H F E$ genotype identical by descent. In addition, among the 18 same sex sibs, two, six, and one sibs were in the normal range of values for transferrin saturation percentage $(<43 \%)$, serum ferritin concentration $(<300 \mu \mathrm{g} / \mathrm{l})$, and serum iron concentration $(<20 \mu \mathrm{mol} / \mathrm{l})$, respectively.

Moreover, in a family of five HFE identical sibs homozygous for the $\mathrm{C} 282 \mathrm{Y}$ mutation, ranging in age from 53 to 61 years old, the sibs displayed variable biochemical expression of iron loading (fig 2). One 60 year old female had no significant increase of any of the iron parameters. Her two sisters (mother of four and two children, respectively) and two brothers, who were C282Y homozygotes, were affected with $\mathrm{HH}$ and showed iron overload according to their iron status parameters.

Another case of discrepancy between genotype and phenotype was discovered in a female homozygous for the C282Y mutation; she had five children. Her husband was genotyped to evaluate the potential risk for the children of having $\mathrm{HH}$. He was found to be homozygous for C282Y and his biochemical iron status at 61 years of age did not show any sign of iron loading (fig 3). Their son, 35 years old and C282Y homozygous, showed signs of iron overloading whereas of their four daughters, aged 30 to 40 years old, only the oldest showed raised transferrin saturation and serum iron concentration.

\section{Discussion}

The present study reports on the relationship between the biochemical expression of iron loading and the homozygous genotype for the $\mathrm{C} 282 \mathrm{Y}$ mutation. Iron loading was first examined in a series of 545 probands homozygous for the C282Y mutation. The iron loading was significantly lower in females than in males whatever the parameter investigated; moreover the study confirmed the reduced penetrance of $\mathrm{C} 282 \mathrm{Y}$ in females with a male to female sex ratio of $1.7: 1$ in probands with clinical $\mathrm{HH}$. The biochemical expression of $\mathrm{HH}$, lower in females than in males, indicated that some C282Y homozygous females may not develop signs of iron overload. In a family study, one case of a female identical by descent to four sibs homozygous for C282Y and diagnosed with $\mathrm{HH}$ did not reach the threshold values for iron

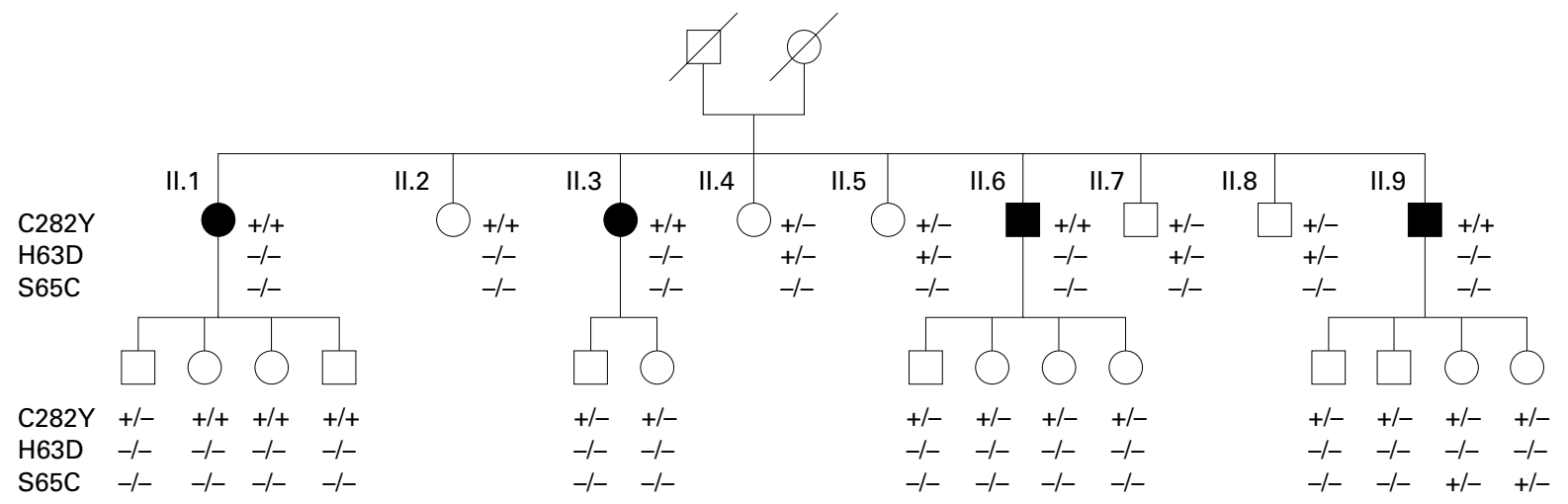

\begin{tabular}{llllllllll}
\hline & II.1 & II.2 & II.3 & II.4 & II.5 & II.6 & II.7 & II.8 & II.9 \\
\hline Age at diagnosis & 60 & $\mathbf{5 6}$ & 53 & 62 & 55 & 61 & 46 & 45 & 57 \\
Transferrin saturation (\%) & 79 & $\mathbf{4 6}$ & 61 & 44 & 46 & 92 & 39 & 17 & 91 \\
Serum ferritin $(\mu \mathrm{g} / \mathrm{l})$ & 445 & $\mathbf{9 3}$ & 279 & 167 & 93 & 1763 & 155 & 139 & 860 \\
Serum iron $(\mu \mathrm{mol} / \mathrm{l})$ & 38 & $\mathbf{2 0}$ & 31 & 22 & 22 & 46 & 24 & 11 & 40
\end{tabular}

Figure 2 A familial case of a female (II.2) homozygous for the C282Y mutation without haemochromatosis. The genotypes are given in order C282Y, H63D, and S65C. + indicates the presence of the mutant allele and - the presence of the wild type allele. 


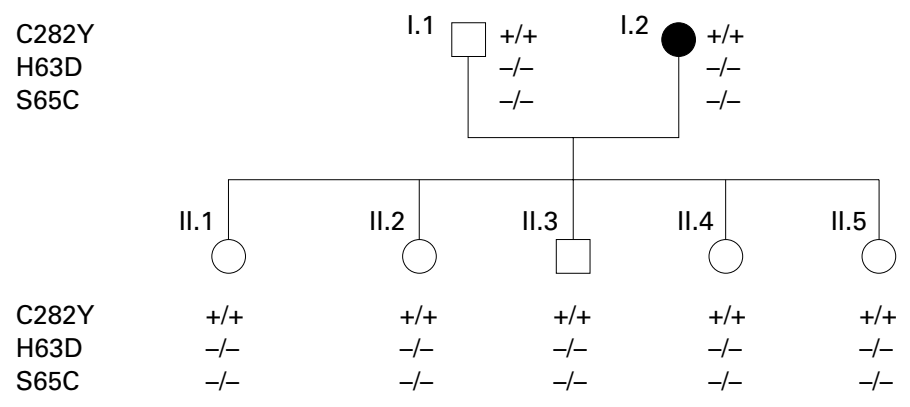

\begin{tabular}{lllll}
\hline & $\mathbf{I . 1}$ & $\mathrm{I} .2$ & 1.3 & 1.4 \\
\hline Age at diagnosis & $\mathbf{6 7}$ & 55 & 35 & 32 \\
Transferrin saturation $(\%)$ & $\mathbf{2 5}$ & 50 & 51 & 72 \\
Serum ferritin $(\mu \mathrm{g} / \mathrm{l})$ & $\mathbf{4 1}$ & 352 & 252 & 116 \\
Serum iron $(\mu \mathrm{mol} / \mathrm{l})$ & $\mathbf{1 4 . 8}$ & 22.2 & 29 & 33
\end{tabular}

Figure 3 A male case (I.1) homozygous for the C282Y mutation without reaching iron status level for haemochromatosis. The genotypes are given in order C282Y, H63D, and S65C. +indicates the presence of the mutant allele and - the presence of the wild type allele.

overload expression defined for haemochromatosis, which indicated that the $\mathrm{C} 282 \mathrm{Y}$ mutation did not show complete penetrance in females.

In this series, iron marker values ranged between normal and significantly increased; transferrin saturation percentage seemed to be the best parameter to predict haemochromatosis in young $\mathrm{C} 282 \mathrm{Y}$ homozygous subjects whereas serum ferritin, the only value to increase progressively, was proved better to show overloading extent. This study thus confirmed that the extent of iron loading in haemochromatosis $\mathrm{C} 282 \mathrm{Y}$ homozygotes is directly related to the age and sex of probands. ${ }^{23-25}$ However, when considering age range, large variations in iron status values were observed in subjects homozygous for C282Y mutation; serum ferritin showed the largest variation. We thus checked for intrafamilial variation of iron markers in sib pairs homozygous for the C282Y mutation. The lack of correlation between sibs and the significant differences of the iron marker values between sib pairs clearly showed a variable biochemical expression of iron overload in sibs with genotype identical by descent at the HFE locus. Although the expression of the disease is strongly influenced by the C282Y mutation, an intrafamilial study of subjects also confirmed that an identical genotype for the $H F E$ gene can show variable iron loading; thus, intrafamilial variations in iron loading do not only represent a variation in the genetic expression of the HFE gene. The cases of non-expressing C282Y homozygous males aged over 60 years old, and displaying iron parameters in the normal range, as reported here and by others, ${ }^{26}$ showed that the biochemical expression of $\mathrm{HH}$ is under the influence of other factor(s). In the families studied, transferrin saturation, serum ferritin, and serum iron variations could result from environmental and non-genetic factors or other genetic factors than those examined. Recent population studies have shown that, compared with non-carriers, any genotype group defined as carriers of a $H F E$ mutation had higher mean serum iron concentration and mean transferrin saturation, whereas only C282Y homozygotes showed higher serum ferritin concentration ${ }^{23}$; they also highlighted that some C282Y heterozygotes could be diagnosed as $\mathrm{HH}^{22}$ Thus, despite a good correlation between HFE defined genotypes and phenotype in population studies, $H F E$ genotyping does not show a clear level of iron loading in subjects and may have implications in genetic counselling.

- Hereditary haemochromatosis $(\mathrm{HH})$ is a common autosomal recessive disease characterised by progressive iron overload. The identification of the $H F E$ gene and mutations involved in haemochromatosis allows direct genetic testing for diagnosis. However, correlations between phenotype and HFE genotypes showed discrepancies and mutation penetrance raises questions.

- We examined the iron loading status in 545 probands and 18 same sex sibs, all homozygous for the C282Y mutation.

- Our data support transferrin saturation percentage and serum ferritin concentration as the best biochemical iron marker for $\mathrm{HH}$ phenotype in young subjects and extent of overload in these patients, respectively. The results also confirm a clear correlation of the iron loading level with age and sex of the patients. However, the lack of correlation of the iron marker status between pairs of sibs, homozygous for C282Y identical by descent, indicated a variable phenotypic expression of iron loading independent of HFE genotype.

This work was supported by INSERM grants from CRI 9607 and Association de Transfusion Sanguine et de Biogénétique Gaetan Saleun.

1 Edwards CQ, Griffen LM, Goldgar D, Drummond C, Skolnick MH, Kushner JP. Prevalence of hemochromatosis among 11065 presumably healthy blood donors. N Engl f Med 1988;318:1355-62.

2 Leggett BA, Halliday JW, Brown NN, Bryant S, Powell LW. Prevalence of haemochromatosis among asymptomatic Australians. Br F Haematol 1990; 74:525-30.

3 Niederau C, Fisher R, Purschel A, Stremmel W, Haussinger $D$, Strohmeyer G. Long-term survival in patients with hereditary hemochromatosis. Gastroenterology 1996;110: 1107-19.

4 Feder JN, Gnirke A, Thomas W, Tsuchihashi Z, Ruddy DA, Basava A, Dormishian F, Domingo R, Ellis MC, Fullan A, Basava A, Dormishian F, Domingo R, Ellis MC, Fullan A,
Hinton LM, Jones NL, Kimmel BE, Kronmal GS, Lauer P, Hinton LM, Jones NL, Kimmel BE, Kronmal GS, Lauer P, Mintier GA, Moeller N, Moore T, Morikang E, Prass CE, Quintana L, Starnes SM, Schatzman RC, Brunke KJ, Drayna DT, Rish NJ, Bacon BR, Wolff RK. A novel MHC class I-like gene is mutated in patients with hereditary haemochromatosis. Nat Genet 1996;13:399-408.

5 Mercier B, Mura C, Férec C. Putting a hold on HLA-H. Nat Genet 1997;15:34

6 Parkkila S, Waheed A, Britton RS, Bacon BR, Zhou XY, Tomatsu S, Fleming RE, Sly WS. Association of the transferrin receptor in human placenta with HFE, the protein defective in hereditary hemochromatosis. Proc Natl Acad Sci USA 1997;94:13198-202.

7 Feder JN, Penny DM, Irrinki A, Lee VK, Lebron JA, Watson N, Tsuchihashi Z, Sigal E, Bjorkman PJ, Schatzman RC. The hemochromatosis gene product complexes with the transferrin receptor and lowers its affinity for

8 Zhou XY, Tomatsu S, Fleming RE, Parkkila S, Waheed A, Jiang J, Fei Y, Brunt EM, Ruddy DA, Prass CE, Schatzman RC, O'Neil R, Britton RS, Bacon BR, Sly WS. HFE gene 
knockout produces mouse model of hereditary hemoknockout produces mouse model of hereditary hem
chomatosis. Proc Natl Acad Sci USA 1998;95:2492-7.

9 Waheed A, Parkkila S, Saarnio J, Fleming RE, Zhou XY, Tomatsu S, Britton RS, Bacon BR, Sly WS. Association of HFE protein with transferrin receptor in crypt enterocytes of human duodenum. Proc Natl Acad Sci USA 1999;96: 1579-84

10 Jazwinska EC, Cullen LM, Busfield F, Pyper WR, Webb SI, Powell LW, Morris CP, Walsh TP. Haemochromatosis and HLA-H. Nat Genet 1996;14:249-51.

11 Carella M, D'Ambrosio L, Totaro A, Grifa A, Valentino MA, Piperno A, Girelli D, Roetto A, Franco B, Gasparin $\mathrm{P}$, Camashella C. Mutation analysis of the HLA-H gene in Italian hemochromatosis patients. Am $\mathcal{F} \mathrm{Hum}$ Genet 1997;60:828-32.

12 Beutler E, Gelbart T, West C, Lee P, Adams M, Blackstone $R$, Pockros P, Kosty M, Venditti CP, Phatak PD, Seese NK, R, Pockr KA, Te Ml, Chorney KA, Ten Elshof AE, Gerhard GS, Chorney M Mutation analysis in hereditary

13 Mura C, Nousbaum JB, Verger P, Moalic MT, Raguenes O, Mercier AY, Ferec C. Phenotype-genotype correlation in Mercier AY, Ferec C. Phenotype-genotype correlation

14 Risch N. Haemochromatosis, HFE and genetic complexity. Nat Genet 1997;17:375-6.

15 Beutler E. The significance of the $187 \mathrm{G}$ (H63D) mutation in hemochromatosis. Am f Hum Genet 1997;61:762-4.

16 Feder JN, Tsuchihashi Z, Irrinki A, Lee VK, Mapa FA, Morikang E, Prass CE, Starnes SM, Wolff RK, Parkkila S, Sly WS, Schatzman RC. The hemochromatosis founde mutation in HLA-H disrupts $\beta 2$-microglobulin interaction and cell surface expression. F Biol Chem 1997;272:14025-8.

17 Waheed A, Parkkila S, Zhou XY, Tomatsu S, Tsuchihashi Z, Feder JN, Schatzman RC, Britton RS, Bacon BR, Sly WS. Hereditary hemochromatosis: effects of C282Y and H63D mutations on association with $\beta 2$-microglobulin, intracellumutatons of the HFE protein in COS-7 cells. Proc Natl Acad Sci USA 1997;94: 12384-9.
18 Mura C, Raguenes O, Férec C. HFE mutations analysis in 711 hemochromatosis probands: evidence for S65C implication in mild form of hemochromatosis. Blood 1999;93: 2502-5.

19 Jouanolle AM, Gandon G, Jézéquel P, Blayau M, Campion ML, Yaouanq J, Mosser J, Fergelot P, Chauvel B, Bouric P, Carn G, Andrieux N, Gicquel I, Le Gall JY, David V. Haemochromatosis and HLA-H. Nat Genet 1996;14:2512.

20 Pinson S, Yaouanq J, Jouanolle AM, Turlin B, Plauchu H. Non-C282Y familial iron overload: evidence for locus 954-6.

21 Roetto A, Totaro A, Cazzola M, Cicilano M, Bosio S, D'Ascola G, Carela M, Zelante L, Kelly AL, Cox TM, Gasparini P, Camaschella C. Juvenile hemochromatosis locus maps to chromosome 1q. Am f Hum Genet 1999;64: 1388-93.

22 Crawford DHG, Jazwinska EC, Cullen LM, Powell LW. Expression of HLA-linked hemochromatosis in subjects homozygous or heterozygous for the $\mathrm{C} 282 \mathrm{Y}$ mutation. Gastroenterology 1998;114:1003-8.

23 Burt MJ, George PM, Upton JD, Collett JA, Frampton CMA, Chapman TM, Walmsley TA, Chapman BA. The significance of haemochromatosis gene mutations in the general population: implications for screening. Gut 1998; general po

24 Bulaj ZJ, Griffin LM, Jorde LB, Edwards CQ, Kushner JP. Clinical and biochemical abnormalities in people heterozygous for hemochromatosis. N Engl f Med 1996;335: 1799-805.

25 Borecki IB, Rao DC, Yaounq J, Lalouel JM. Serum ferritin as a marker of affection for genetic hemochromatosis. Hum Hered 1990;40:159-66.

26 Rhodes DA, Raha-Chowdhury R, Cox TM, Trowsdale J. Homozygosity for the predominant Cys282Tyr mutation and absence of disease expression in hereditary haemochromatosis. F Med Genet 1997;34:761-4.

\section{Haptoglobin genotype as a risk factor for postmenopausal osteoporosis}

7 Med Genet

2001;38:636-638

Department of

Genetic, Biology and

Biochemistry,

University of Torino,

Italy

G P Pescarmona

E Morra

Department of Internal Medicine, University of Torino,

Italy

P D'Amelio

G C Isaia

Correspondence to: Professor Isaia, UOADU Medicina Malattie Metaboliche dell'Osso, Dipartimento di Medicina Interna, Facoltà di Medicina e Chirurgia, Università di Torino, Corso Dogliotti 14 10126 Torino, Italy, isaia@molinette.unito.it

Gian Piero Pescarmona, Patrizia D’Amelio, Emanuella Morra, Gian Carlo Isaia

EDITOR-Some epidemiological and experimental data have shown a correlation between iron metabolism and calcium, phosphate, and magnesium turnover. ${ }^{12}$ In particular, previous reports have shown that iron availability can play a fundamental role in bone metabolism and that iron depletion can lead to bone demineralisation. For example, in patients who underwent gastrectomy $y^{3-5}$ or in rats treated similarly, ${ }^{6}$ osteoporosis was accompanied by laboratory and clinical signs of iron deficiency and was prevented by the administration of fructo-oligosaccharides, a substance that promotes iron absorption from the gut. In oophorectomised rats (a condition mimicking the oestrogen levels commonly found in the menopause), a wide range of cells, including osteoblasts, displayed a reduced number of transferrin receptors and hence a reduced iron uptake. ${ }^{7}$ In humans, it has been assessed that out of 14 nutrients tested (including calcium), iron was the best positive predictor of BMD in the femoral neck, ${ }^{8}$ and furthermore a negative correlation between ascorbic acid content of the diet and osteoporosis has been found ${ }^{9}{ }^{10}$; it is notable that ascorbic acid in the diet affects iron absorption increasing it by a factor of 2-3. A severe nutritional iron deficiency anaemia provokes significant alterations in the metabolism of calcium, phosphorus, and magnesium in rats with a noticeable degree of bone demineralisation, even in the presence of normal serum levels of calcium, phosphorus, and magnesium.

On the basis of the above evidence, we searched for a genetic marker of iron disposal (haptoglobin genotype) as a risk factor for postmenopausal osteoporosis.

Only about $5 \%$ of daily iron turnover comes from intestinal absorption, most of it coming from haemoglobin turnover, which requires three proteins, haemopexin, haptoglobin, and haem oxygenase. We focused our attention on haptoglobin since it is the only one with a well known polymorphism.

Haptoglobin (HP) is a serum $\alpha 2$ glycoprotein that exists as a tetramer, composed of two smaller identical alpha $(\alpha)$ and two larger identical beta $(\beta)$ chains. At present, three main different genotypes of haptoglobin in normal adult plasma have been identified. Differences among the three haptoglobin genotypes are given by light alpha subunit structures: type 1.1 , type 2.2 , which has homozygous $\alpha 1$ (9 $\mathrm{kDa})$ and $\alpha 2(18 \mathrm{kDa})$ subunits, and type 2.1, which has heterozygous $\alpha 1$ and $\alpha 2$ subunits, with a shared $\beta$ subunit in all three genotypes (38 $\mathrm{kDa})$. The $\beta$ chain is a glycoprotein which does not exhibit polymorphism but only some rare variants. 


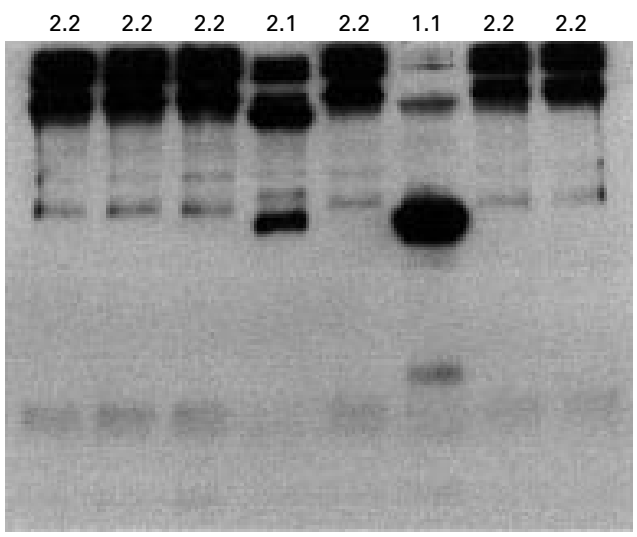

Figure 1 Electrophoretic runs of haptoglobin: type 1 appears as a single band furthest from the origin, while types $2.1(200 \mathrm{kDa})$ and $2.2(400 \mathrm{kDa})$ appear as a series of bands nearer to the origin.

The main function of haptoglobin is to bind free haemoglobin in a stable complex, which is later cleared from the plasma by the liver reticuloendothelial system. Haemoglobin binding capacity depends on the genetic haptoglobin type, on the amount of haptoglobin, and on the number of polymers. ${ }^{11} 12$

Functional differences between haptoglobin genotypes have been described ${ }^{12}$; type 1.1 has the highest haemoglobin carrying ability, while type 2.2 is almost unable to carry it because the $\mathrm{Hb}$ binding site is buried by the polymerisation process.

In European populations, the genotype distribution is as follows: about $16 \%$ has genotype 1.1 , about $48 \%$ genotype 2.1 , and the remaining $36 \%$ genotype $2.2 .{ }^{13}$ Several authors have studied the haptoglobin haplotype frequency in different populations and different pathologies ${ }^{1314}$ and various haptoglobin genotypes have also been correlated with the serum iron. ${ }^{12}$ In spite of the large number of published reports on the topic, no study has been performed to investigate a possible difference in the incidence of haptoglobin genotypes in osteoporotic patients and non-osteoporotic subjects.

In order to investigate the possible correlations between postmenopausal osteoporosis and frequencies of haptoglobin genotypes, we studied a group of women affected by postmenopausal osteoporosis and a control group of non-osteoporotic postmenopausal women.

\section{Methods}

The osteoporotic group consisted of 135 subjects (age range 40-73 years, postmenopausal age range 6 months-26 years) and the osteoporosis was diagnosed using the Double Emission $X$ ray Absorptiometry (DXA) technique

Table 1 Characteristics of the patients compared to the controls (age, postmenopausal age, $B M I, T$ score). Shown are the mean values, the standard deviation (SD), and the result of Student's $t$ test

\begin{tabular}{lcclllll}
\hline & \multicolumn{2}{l}{ Patients $(n=135)$} & & \multicolumn{2}{c}{ Controls $(n=65)$} & \\
\cline { 2 - 3 } & Mean & $S D$ & & Mean & $S D$ & $p$ \\
\hline Age & 57.7 & 5.4 & & 60 & 7.2 & 0.01 \\
Postmenopausal age & 8.7 & 6.5 & & 10.7 & 7.9 & 0.05 \\
BMI & 24 & 13.9 & & 24.6 & 4.2 & NS \\
$t$ score & -3.16 & 0.55 & & -0.76 & 0.56 & $<0.0001$ \\
\hline
\end{tabular}

with a Hologic QDR4500 densitometer (Hologic Inc, Waltam, MA, USA). In particular, we considered as osteoporotic patients with a $\mathrm{T}$ score value of $2.5 \mathrm{SD}$ or less, according to WHO (WHO Technical Report Series No 843 "Assessment of fracture risk and the application to screening for postmenopausal osteoporosis", 1994). Secondary osteoporosis was excluded by history, physical examination, and measurement of calcium, phosphorus, and bone alkaline phosphatase (BAP) in the blood.

The control group consisted of 65 nonosteoporotic women (age range 47-76 years, postmenopausal age range 6 months- 33 years) (T score $>-1 \mathrm{SD}$ ).

The HP genotypes of patients and controls were analysed with SDS-PAGE electrophoresis (fig 1). Data were analysed by the $\chi^{2}$ test using the Statistical Analysis System (SAS Institute Inc). The odds ratio and the corresponding confidence interval were also calculated for genotype 1.1 versus genotype 2.2 and 2.1 . To avoid possible selection bias, we compared the patients and the control group for age, postmenopausal age, body mass index (BMI), and $\mathrm{T}$ score (table 1 ). The controls were, on average, older than the patients $(\mathrm{p}=0.01)$ with a longer postmenopausal period $(\mathrm{p}=0.05)$.

\section{Results}

The frequencies of the three haptoglobin genotypes are $32.6 \%$ for $2.2,55.5 \%$ for 2.1 , and $11.9 \%$ for 1.1 in the patient group, while in the control group they are $47.7 \%, 50.8 \%$, and $1.5 \%$, respectively, with significant differences between the two groups $\left(p=0.0076, \chi^{2}\right.$ test). The odds ratio between genotype 1.1 and genotype 2.2 was 12 (confidence interval = 1.34-106.7). The odds ratio between genotype 1.1 and genotype 2.1 was 7.04 (confidence interval $=1.21-2.9$ )

\section{Discussion}

It is well known that advancing age, a prolonged period of amenorrhoea, and low BMI are risk factors for osteoporosis. Any possible bias in selection of subjects was excluded as the controls were on average significantly older and the BMI of the two groups was not significantly different.

Our data show that the presence of haptoglobin genotype 1.1 is an important risk factor for postmenopausal osteoporosis. The functional differences between haptoglobin genotypes, namely the fact that type 1.1 has the highest haemoglobin carrying ability and, hence, the highest elimination rate through the liver, while type 2.2 is almost unable to carry it to the liver, can account on a molecular basis for the increased risk for osteoporosis linked to the presence of haptoglobin genotype 1.1. In normal subjects, the amount of iron stores (namely ferritin) is significantly correlated with the HP genotype. ${ }^{12}$

The daily requirement of iron intake to keep the body iron store stable is therefore strongly dependent on the ability of the organism to store iron (HP 2.2) or to waste it (HP 1.1) through the liver. 
The finding that HP genotype may play an important role as a risk factor for osteoporosis may be useful in clinical practice to identify in advance the women who will probably develop postmenopausal osteoporosis and so allow primary prevention of the disease and reduce the social cost of its consequences.

f Med Genet

2001;38:638-643

Laboratoire de

Génétique

Moléculaire, Faculté

des Sciences

Pharmaceutiques et

Biologiques,

Université Paris V

René-Descartes, 4

Avenue de

l'Observatoire, 75006

Paris, France

$M$ Bahuau*

D Vidaud

$M$ Vidaud

Unité de Recherches sur les Handicaps Génétiques de

l'Enfant, INSERM

U-393, Hôpital Necker

Enfants-Malades,

Assistance

Publique-Hôpitaux de

Paris, 149 Rue de

Sèvres, 75743 Paris

Cedex 15, France

A Pelet

A Munnich

S Lyonnet

Service de Pédiatrie et Génétique Médicale,

Groupe Hospitalier

Pellegrin, Centre

Hospitalier

Universitaire de

Bordeaux, 33076

Bordeaux Cedex,

France

T Lamireau

D Lacombe

Laboratoire

d'Anatomie et

Cytologie

Pathologiques, Groupe

Hospitalier Pellegrin,

Centre Hospitalier

Universitaire de

Bordeaux, 33076

Bordeaux Cedex,

France

B Le Bail

Correspondence to: $\mathrm{Dr}$

Vidaud,

mvidaud@teaser.fr

or Dr Lyonnet,

lyonnet@necker.fr

${ }^{\star}$ Present address: Service de Biochimie et Biologie

Moléculaire, Hôpital

d'Enfants

Armand-Trousseau,

Assistance

Publique-Hôpitaux de Paris,

75571 Paris Cedex 12,

France
This work was supported by a grant from the Ministero dell'Università e della Ricerca Scientifica e Tecnologica (MURST, $60 \%$ ) of Italy.

1 Campos MS, Barrionuevo M, Alferez MJ, Gomez-Ayala AE, Rodriguez-Matas MC, Lopez O. Interactions among ally iron-deficient rat. Exp Physiol 1998;83:771-81.

2 Sinigaglia L, Fargion S, Fracanzani AL, Binelli L, Battafarano N, Varenna M, Piperno O, Fiorelli G. Bone and joint ano $\mathrm{N}$, Varenna $M$, Piperno $O$, Fiorelli $G$. Bone and joint involvement in genetic hemochromatosis: role of cirrhosis and iron overload. F Rheumatol 1997;24:1809-13. Lundberg PA, Obrant K, Schoon IM, Toss G, Ytterberg BO. Osteoporosis, metabolic aberrations, and increased risk for vertebral fractures after partial gastrectomy. Calcif Tissue Int 1993;53:370-7.

4 Maier GW, Kreis ME, Zittel TT, Becker HD. Calcium regulation and bone mass loss after total gastrectomy in pigs. Ann Surg 1997;225:181-92. iron, calcium, phosphorus and magnesium in the nutrition-

3 Mellstrom D, Johansson C, Johnell O, Lindstedt G,
EDITOR-Neurofibromatosis type $1(\mathrm{NF} 1)$ is a common human disorder (1/3500 live births) with neuroectodermal involvement primarily resulting in dermatological manifestations of café au lait spots, cutaneous/subcutaneous neurofibromas, and freckling of major skin folds. ${ }^{1}$ Owing to diagnostic uncertainties, especially in young patients, an international scoring system has been discussed and agreed upon. ${ }^{2}$ Half of the cases result from new mutations, while others show an autosomal dominant mode of inheritance. The encoded product, referred to as neurofibromin, is a member of the so called GTPase activating proteins (GAPs), and is an upstream downregulator of the RAS(p21)/RAF/MAPkinase ${ }^{3}$ and RAS/RAL ${ }^{4}$ signalling pathways. Although locus homogeneity is a hallmark of this condition, phenotypic heterogeneity has been exemplified by a wide spectrum of diversity ranging from malformation or malignant variants to virtually benign dermatological changes. ${ }^{1}$ In particular, and among the many causes of gastrointestinal involvement in NF1 patients, the association with intrinsic intestinal dysmotility, resulting from intestinal neuronal dysplasia type $\mathrm{B}$ (IND B) ${ }^{56}$ or aganglionic megacolon (Hirschsprung's disease, HSCR), ${ }^{7}$ has been documented and is now well established.

Interestingly, a substantial fraction of the phenotypic variability seen in NF1 patients
5 Tovey FI, Godfrey JE, Lewin MR. A gastrectomy population: $25-30$ years on. Postgrad Med f 1990;66:450-6. 6 Ohta A, Ohtsuki M, Uehara M, Hosono A, Hirayama M, Adachi T, Hara H. Dietary fructooligosaccharides prevent postgastrectomy anemia and osteopenia in rats. $\mathcal{F}$ Nutr 1998;128:485-90.

7 Idzerda RL, Huebers H, Finch CA, McKnight GS. Rat transferrin gene expression: tissue-specific regulation by
iron deficiency. Proc Natl Acad Sci USA 1986;83:3723-7.

8 Angus RM, Sambrook PN, Pocock NA, Eisman JA. Dietary Angus RM, Sambrook PN, Pocock NA, Eisman JA. Dietary
intake and bone mineral density. Bone Miner 1988;4:265intake

9 Falch JA, Mowe M, Bohmer T. Low levels of serum ascorbic acid in elderly patients with hip fracture. Scand $\mathcal{F}$ Clin Lab Invest 1998;58:225-8.

10 Melhus H, Michalsson K, Holmberg L, Wolk A, Ljunghall S. Smoking, antioxidant vitamins, and the risk of hip fracture. F Bone Miner Res 1999;14:129-35.

11 Langlois M, Delanghe J, Boelaert J. Haptoglobin polymorphism, a genetic marker of oxidative stress in HIV-infection. International Conference on HIV and Iron, Brugge, Belgium, 14-15 March 1997.

12 Delanghe J, Langlois M, Boelaert J, Van Acker J, Van Wanzeele F, van der Groen G, Hemmer R, Verhofstede C, De Buyzere M, De Bacquere D, Arendt V, Plum J. Haptoglobin polymorphism, iron metabolism and mortality in HIV infection. AIDS 1998;12:1027-32.

13 Teige B, Olaisen B, Teisberg P. Haptoglobin subtypes in Norway and a review of $\mathrm{Hp}$ subtypes in various population. Hum Hered 1992;42:93-106.

14 Subramanian VS, Krishnaswami CV, Damodaran C. HLA, ESD, GLOI, C3 and HP polymorphisms and juvenile insulin dependent diabetes mellitus in Tamil Nadu (south India). Diabetes Res Clin Pract 1994;25:51-9.

\section{$G D N F$ as a candidate modifier in a type 1 neurofibromatosis (NF1) enteric phenotype}

Michel Bahuau, Anna Pelet, Dominique Vidaud, Thierry Lamireau, Brigitte Le Bail, Arnold Munnich, Michel Vidaud, Stanislas Lyonnet, Didier Lacombe

might be governed by non-allelic, trait specific, "modifying" loci. ${ }^{8}$ Although the action of such modifying loci has been primarily shown in the number of café au lait spots or the number of cutaneous/subcutaneous neurofibromas, it can be speculated that such a genetic phenomenon might also be operative in other phenotypic traits, especially in individual or familial cases with an enteric phenotype.

The female proband from the family analysed here (fig 1A) had minor cutaneous manifestations of NF1, dysmorphic facial features (midface hypoplasia), congenital heart disease (ventricular septal defect, coarctation of the aorta), and congenital megacolon. She subsequently underwent a Duhamel abdominoperineal pull through and pathological examination of the whole colectomy specimen pointed to IND B (fig 2), because of findings of (1) abnormal submucosal plexuses showing focal hyperplasia (in terms of density and sizes), (2) occasional giant ganglia harbouring $>10$ neurones, and (3) nerve cell buds along afferent nerves. ${ }^{9}$ The older sister also had NF1 and congenital megacolon, while a brother was totally unaffected. NF1 was inherited from the mother and maternal grandmother, who both had a mainly cutaneous form of the condition. The father was healthy. ${ }^{10}$

Although IND B may segregate as a monogenic disorder, no specific locus has been 


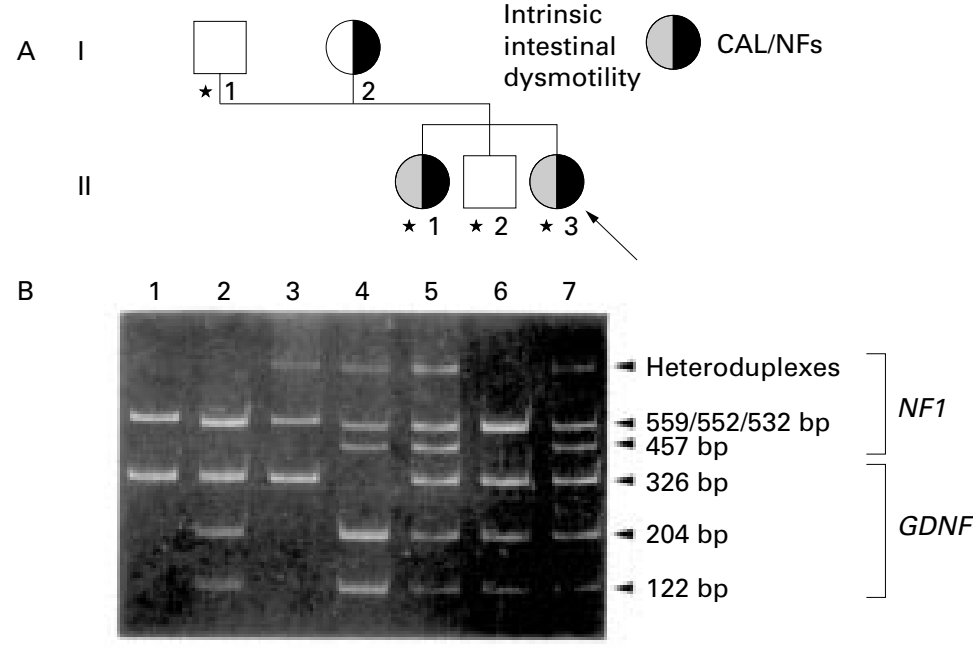

Figure 1 (A) Family pedigree. A miscarriage, which occurred between II. 2 and II.3, is not represented here. $C A L=$ café au lait spots, NFs=neurofibromas. $A$ cytogenetically balanced reciprocal $t(15 ; 16)(q 26.3 ; q 12.1)$ translocation is shared by I.1, II.1, II.2, and II. $3,{ }^{10}$ as indicated by asterisks. (B) NF1 and GDNF restriction. DNA from the proband and relatives was screened for the NF1 lesion with PCR primers and HphI enzyme cleavage as previously stated $d^{51}$ and for the GDNF mutation using the upper primer GDNFEx2F (5'-CAAATATGCCAGAGGATTATC-3') and lower primer GDNFEx2R (5'-TATTTTGTCGTACGTTGTCTC-3') with cycling conditions of $5^{\prime}$ at $94^{\circ} \mathrm{C}$ and 30 rounds of 20 seconds at $94^{\circ} \mathrm{C}, 20$ seconds at $55^{\circ} \mathrm{C}$, and 30 seconds at $72^{\circ} \mathrm{C}$ followed by restriction with HinfI endonuclease. Restriction products were size fractionated through a $8 \%$ polyacrylamide gel, stained with ethidium bromide, and visualised by ultraviolet transillumination. NF1 exon 16 and GDNF exon 2 amplimers are shown unrestricted and restricted for I. 1 (lanes 1 and 2) and I.2 (lanes 3 and 4) and restricted only for II.1, II.2, and II.3 (lanes 5, 6, and 7). Arrowheads indicate theoretical fragment sizes in base pairs $(b p) . H p h I$ restriction of the $552 b p$ wild type NF1 amplimer generates a 532 bp fragment, whereas restriction of the $559 \mathrm{bp}$ mutated amplimer generates a $457 \mathrm{bp}$ fragment. On the other hand, restriction with HinfI of the $326 \mathrm{bp}$ wild type GDNF amplimer generates a 204 $b p$ and a 122 bp fragment but leaves the (326 bp) mutated amplimer unaltered. Only II. 1 and II.3, sharing both the paternally derived GDNF lesion and the maternally inherited NF1 mutation, have megacolon. Note the presence of heteroduplexes in NF1 heterozygotes (lanes 3-5 and 7).

linked to this recognised Mendelian entity (MIM 601223). However, since $\sim 30 \%$ of IND $\mathrm{B}$ patients have accompanying aganglionosis, that is, HSCR, ${ }^{9}$ the RET proto-oncogene, ${ }^{11-13}$ the genes encoding endothelin receptor $\mathrm{B}$ $(E D N R B),{ }^{14-16}$ or its ligand endothelin 3 $(E D N 3)^{17}$ are candidate genes for isolated IND $\mathrm{B}^{18}$. Here, none of these genes was found to be mutated, suggesting that the NF1-IND B combination observed here was indeed an integral NF1 variant. ${ }^{10}$

However, the scarcity of this specific variant and the small family sizes has hindered the identification of modifying loci by phenotype and pedigree based analyses. ${ }^{8}$ The initial observation of an out of frame insertion within NF1 exon 16 (2424-2425insCCTTCAC, fig 1B) favoured a null lesion, that is, it did not support causal genotype-phenotype correlation. The fact that only those relatives with the NF1 mutation and a cytogenetically balanced reciprocal translocation $\mathrm{t}(15 ; 16)$ (q26.3; $\mathrm{q} 12.1)$ (fig 1A) had intrinsic intestinal dysmotility suggested that a modifier gene might have been altered at one of the translocation breakpoints. ${ }^{10}$ However, none of the breakpoint regions is known to harbour a gene involved in the development of the parasympathetic ganglion cells of the digestive tract and this family was investigated further for candidate genetic modifiers lying elsewhere in the genome.

As changes in $G D N F^{19-22}$ and the neurturin gene $(N R T N)^{23}$ suggested polygenic causation of anomalous neural crest cell derived structures, especially parasympathetic enteric neurones, these genes were good candidate modifiers. For this reason, GDNF and NRTN gene exons were analysed for DNA changes by SSCP and sequence analysis, as previously reported. ${ }^{19} 23$ While NRTN showed no sequence variation (data not shown), a missense mutation was found within GDNF exon 2, changing codon 93 from arginine (CGG) to tryptophan (TGG) (R93W, fig 1B). The R93W mutation could be regarded as potentially pathogenic, since (1) it resulted in a nonconservative amino acid change at an evolutionarily conserved residue in the direct vicinity of a putative propeptide cleavage site and transforming growth factor beta (TGFB) related cystein rich motifs, ${ }^{24}(2)$ it was found in other patients with distinct neural crest cell related anomalies such as HSCR (in addition to mutations of RET) ${ }^{21} 22$ or the CCHS-HSCR association, ${ }^{19}$ and (3) it was conspicuously absent from a large number of control DNAs. ${ }^{21}{ }^{25}$ Of interest, this is the first GDNF mutation seen in a patient with IND B without aganglionosis. The recurrence pattern of this mutation is probably explained by its relation to a $\mathrm{CpG}$ dinucleotide mutational hot spot. ${ }^{26}$

GDNF is probably the most powerful neurotrophin identified to date. It is the first identified member of a family of growth factors distantly related to $\mathrm{TGFBs}^{24}$ (see $B \mathrm{Bh}^{27}$ for a recent review and Ramer et $\mathrm{l}^{28}$ for an update on neurotrophic effects), whose action is mediated by binding to a multicomponent system composed of RET receptor tyrosine kinase (RTK) ${ }^{29}$ and glycosylphosphatidylinositol (GPI) linked cell surface adapter proteins (GFRA1, GFRA2). ${ }^{30}{ }^{31}$ Signalling through RET can trigger phosphatidylinositol-3 kinase (PI3K), leading to activation of either members of the RHO family of GTPases (RHO, RAC, and CDC42) with ensuing rearrangements of the actin cytoskeleton and axon outgrowth, or protein kinase $\mathrm{B}(\mathrm{PKB})$ mediated effects on metabolism or gene transcription. Interestingly, in both these pathways, PI3K requires functional RAS ${ }^{32}$ In addition, stimulation of RET leads to SHC-GRB2-SOS complex formation and RAS activation, the RAF and RAL families of GTPases acting as downstream effectors ${ }^{33}$ (fig 3). Although it is difficult to predict the exact outcome of the combination of mutations reported here for the subcellular signalling network, it can be speculated that certain pathways are markedly impaired while others are only mildly affected, especially since the NF1/GDNF double heterozygote infants depicted here have severe developmental alterations but only minor symptoms related to deregulated cell growth. ${ }^{10}$ Of special interest is that one might have expected functional recovery of the NF1 mutation by the GDNF lesion, since NF1 disruption generates activated, GTP bound RAS, whereas low GDNF maintains RAS in the GDP bound form. A possible rationale comes from the observation that RAF1 is able to induce growth arrest and differentiation of discrete human carcinoma 


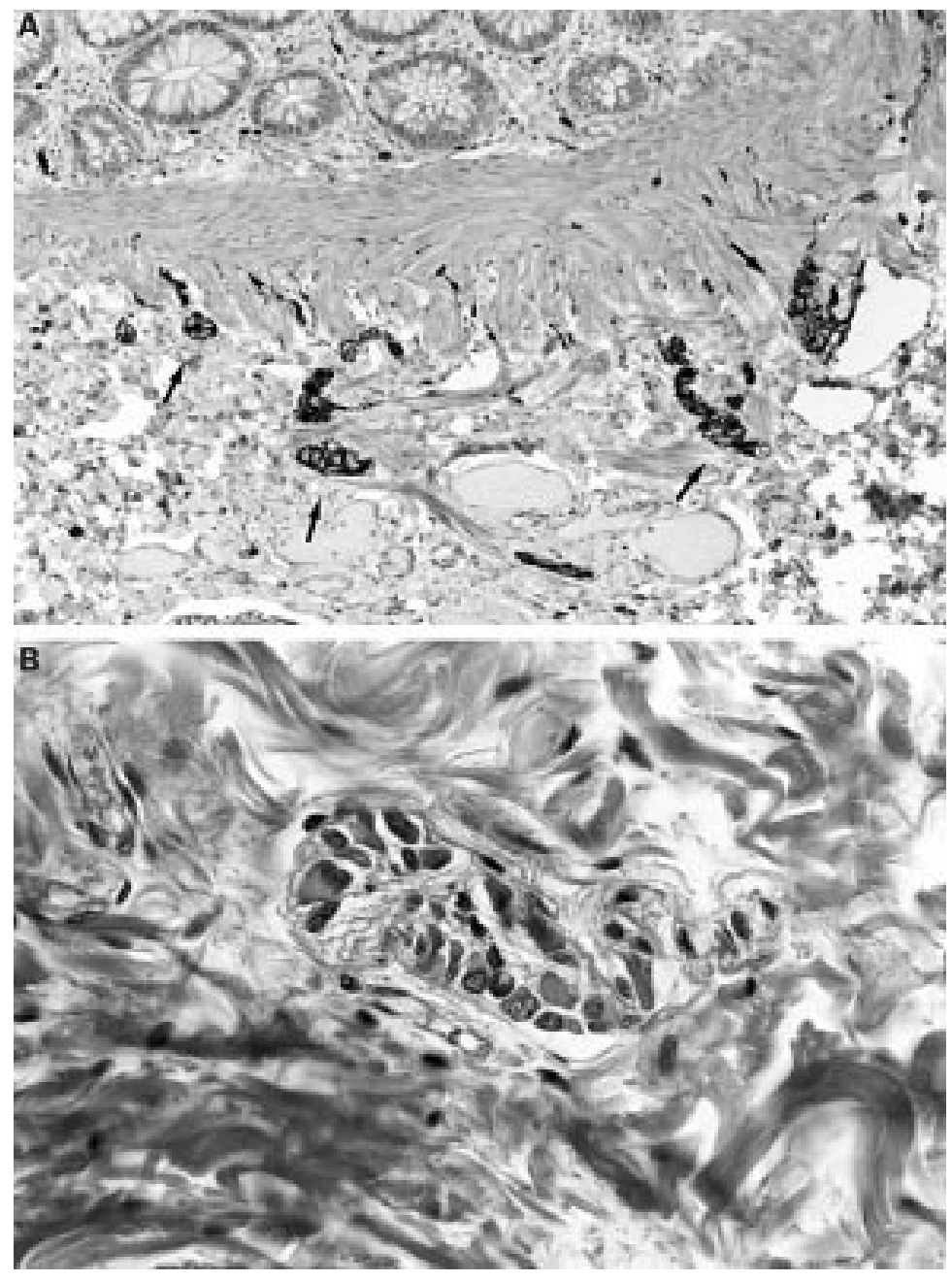

Figure 2 Intestinal neuronal dysplasia. The colectomy specimen was fixed in Bouin's reagent for 12 hours. Transverse sections were cut every centimetre, from both normal and pathological segments, and were routinely processed for histology. Four millimetre serial paraffin embedded sections were stained with haematoxylin-eosin-saffron (HES) for standard light microscopy. Immunodetection of protein S100, a marker of Schwann cells, was used to outline nerve structures. After microwaving for antigen retrieval, paraffin embedded sections were incubated with Dako Z311 anti-S100 antibody (diluted 1/800) in a Ventana ES 320 automated immunostainer, using appropriate immunoperoxidase LSAB detection and revelation kits (Ventana, Tucson, AZ). Sections from normal and pathological specimens were analysed for the presence and density of intramural plexuses, the thickness of nerve trunks, and the features of ganglion cells. (A) Hyperplasia of nerve structures in the lamina propria and muscularis mucosae. Numerous nerve fibres are stained with anti-S100 antibody. Four submucosal plexuses (arrows) contain numerous immunonegative ganglion cells (immunoperoxidase staining). (B) Giant submucosal ganglion containing $\geqslant 12$ distinctive neurones, as shown by characteristic vesicular nuclei and abundant amphophilic cytoplasm (HES).

cell lines, with downregulation of endogenous $R E T^{34}{ }^{35}$ and resistance to activated exogenous $R E T$ alleles. ${ }^{36}$ The bona fide enteric phenotype observed here is indeed consistent with a feedback loop of RAS/RAF downstream effectors upon RET, or at least with a relatively complex interplay of factors influencing cell growth and differentiation. An interesting alternative hypothesis comes from the so called downstream model in which RAS is regarded as a regulator of neurofibromin, the process of RAS conversion from the GTP bound to the GDP bound form inducing neurofibromin to transmit signal through its influences on microtubule organisation. ${ }^{37}$ In that model, both low GDNF and low neurofibromin concur to disrupt the downstream effects of neurofibromin upon cell proliferation or differentiation.
Murine models were generated for both NF1 and GDNF through disruption by homologous recombination in embryonic stem cells. Mice lacking $G d n f\left(G d n f^{\prime}\right)^{38-40}$ had total renal agenesis, resulting from defective induction of the ureteric bud and absent enteric neurones, also consistent with additional manifestations of pyloric stenosis, duodenal dilatation, and congenital megacolon. These models are highly reminiscent of Ret deficient mice $\left(\operatorname{Ret}^{-1 /}\right)$, providing a functional confirmation that GDNF is a ligand of RET. Heterozygotes $\left(G d n f^{+/}\right)$were indiscernible from wild type litter mates. However, heterozygous $N f 1 \mathrm{mu}-$ tants $\left(N f 1^{+/}\right)$do not replicate the human disorder (in particular, they do not develop obvious neurofibromas or pigmentation defects). ${ }^{4142}$ Conversely, these mice are prone to age related tumours, in addition to malignancies reminiscent of human NF1 (especially phaeochromocytomas and myeloid leukaemia). ${ }^{42}$ Interestingly, homozygotes $\left(\mathrm{Nf1}^{-/}\right)$die in utero from severe cardiac malformation, especially involving the neural crest cell derived conotruncus, ${ }^{41}{ }^{42}$ and show hyperplasia of the pre- and paravertebral sympathetic ganglia, ${ }^{41}$ indicating that the phenotype is both dosage sensitive, as in GDNF, and malformative rather than tumourous, eventually confirming the important role of neurofibromin during development. These models and the family presented here suggest murine $\mathrm{Nf1}^{+/-}$x $G d n f^{+/}$intercrosses for the phenotypic analysis of double mutants as an ultimate demonstration of a modifier gene effect. ${ }^{43}$

Modifying genes are not just hypothetical and HSCR families have provided particularly fruitful material for eliciting such entities. Two hitherto anonymous loci have been indicted in polygenic inheritance of HSCR. The first such example was illustrated by a large inbred Mennonite HSCR pedigree that segregated a missense mutation in $E D N R B^{44}$ and otherwise showed linkage disequilibrium with marker alleles mapped to $21 \mathrm{q} 22$. This finding was highly suggestive of a HSCR genetic modifier linked to this chromosomal region, which might elsewhere account for the high HSCR prevalence among trisomy 21 patients. More recently, genome wide non-parametric linkage was performed on a panel of HSCR pedigrees which selected a particular subgroup in the sense that these were either unlinked to $R E T$ or showed positive linkage but with no sequence alteration identified at that locus. From these families, significant linkage to a locus in $9 \mathrm{q} 31$ was found, suggesting that this genetic region contains a gene whose variation entails a specific susceptibility to HSCR, with or without concomitant linkage to $R E T .^{45}$ More straightforward evidence for a HSCR modifier is exemplified by the genes encoding glial cell line derived neurotrophic factor $(G D N F)^{20-22}$ and, more recently, neurturin (NRTN), ${ }^{23}$ two highly homologous natural ligands of the RET tyrosine kinase receptor protein. Indeed, since GDNF and NRTN were found to be mutated in families also segregating well characterised $R E T$ alleles, it was postulated that alterations of these genes were not sufficient in themselves to 


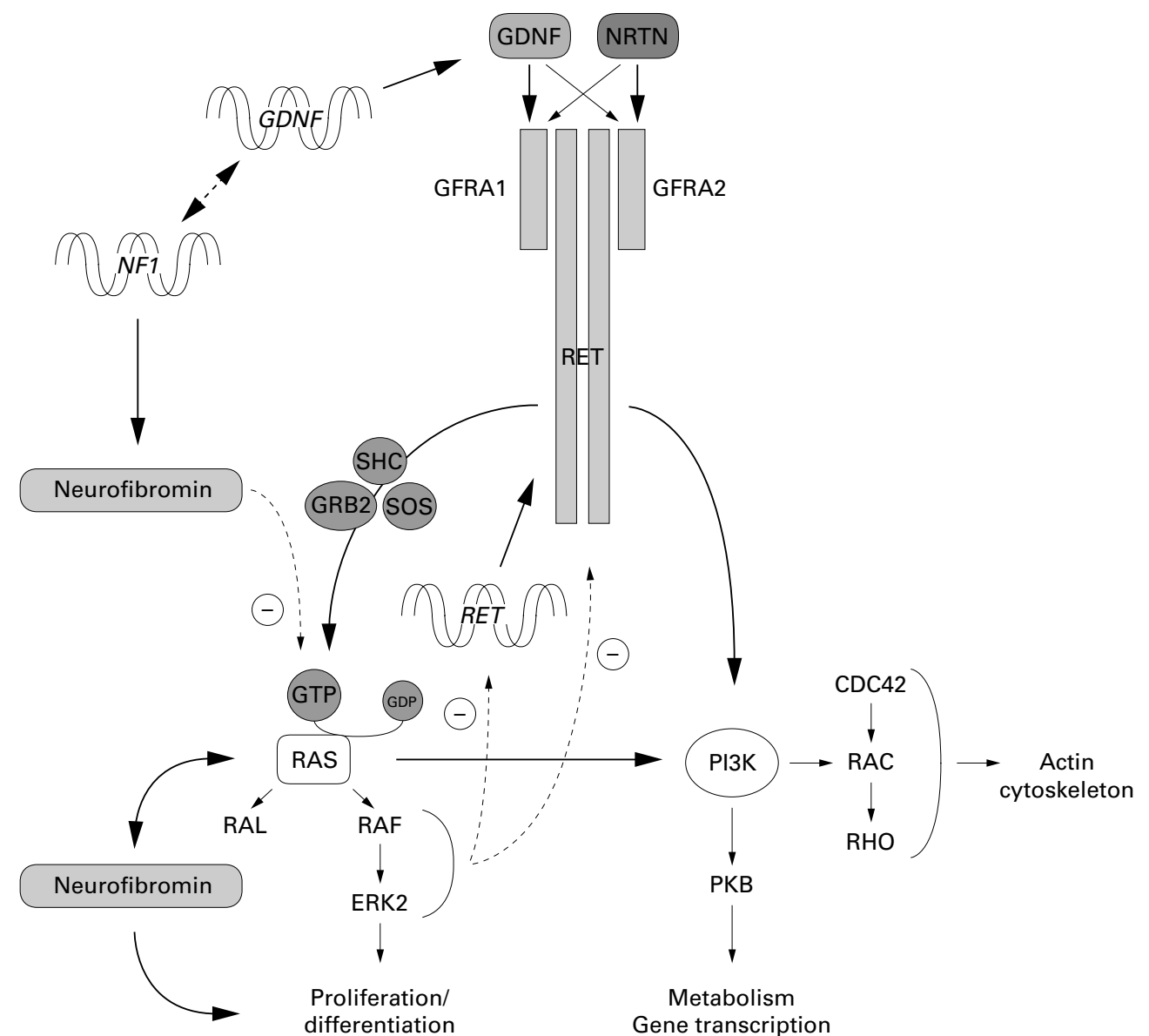

Figure $3 . N F 1$ (neurofibromin) and GDNF signalling partnership. Epistatic interaction of NF1 and GDNF is sustained by the signalling partnership of their respective products, neurofibromin and GDNF. Whereas alteration of GDNF is expected to balance the lack of inhibition of RAS owing to low neurofibromin, the effects on the PI3K dependent pathways are liable to aggravate the negative feedback loop of RAS/RAF on RET and RTK activity (adapted from van Weering and Bos $^{33}$ and others).

cause HSCR, but that they probably contributed to the severity of the phenotype or to higher penetrance of the RET mutations.

Although molecular evidence for modification proper in the pathogenesis of human NF1 has not been provided to date, the possibility of epistatic interaction of the NF1 (Nf1) gene with other discrete loci was recently illustrated both in man and in a murine model for human NF1.

Human pedigrees with hereditary nonpolyposis colorectal cancer (HNPCC) have been reported in which children homozygous (doubly heterozygous) for an $M L H 1$ mutation were shown to develop extracolonic malignancies of early onset and de novo NF1. ${ }^{46}{ }^{47}$ These observations suggest that the NF1 gene is prone to common replication errors during mitosis and/or meiosis, and that MLH1 plays a particular role in monitoring these types of DNA lesions. These very important observations point to mismatch repair (MMR) genes as possible targets during NF1 tumour advancement and shed new light onto the rather unexpected microsatellite instability observed in NF1 derived tumours. ${ }^{48}$

In mice, different combinations of mutations of Nf1 and/or Trp53 (homologous to TP53) were generated through intercrosses. ${ }^{49} 50$ The first remarkable observation was that, unlike their $N f 1^{+/}$or $N f 1^{-/}$congeners, mice that were haploinsufficient for both $N f 1$ and Trp53 developed benign or malignant peripheral nerve sheath tumours (MPNSTs) and malignant Triton tumours reminiscent of human NF1. In addition, permanent cell lines established from some of these mice showed a pattern of gene expression consistent with immortalisation of pluripotent neural crest stem cells, whether the original tumours were of seemingly mesodermal or of conspicuous neural crest origin. ${ }^{50}$ These data provide further evidence of linkage of RAS with the cell cycle machinery, especially with the pathways that are linked with the activation of TP53, and confirm the commonality of neural crest involvement in NF1 pathogenesis. In addition, these intercrosses clearly support the hypothesis that functional proteinprotein interaction is a strong substratum for epistasis or modification.

In the family presented here, especially in the two infants who are doubly heterozygous for the NF1/GDNF lesions, it is questionable whether GDNF modification accounts for wider involvement of neural crest cell derivatives, such as midface hypoplasia (through disruption of the cranial crest mesectoderm) or conotruncal heart disease (VSD and coarctation of the aorta), also observed in the proband. Whatever the case, our findings seemingly confirm the previous speculation 
that genes whose products interact functionally with RAS are potential NF1 modifiers. ${ }^{43}$ Once identified, these modifiers will provide tools to unravel interactions with the subcellular signalling network in NF1 patients and may lay the basis for new therapeutic approaches.

- A family with neurofibromatosis type 1 (NF1, MIM 162200) and congenital megacolon (intestinal neuronal dysplasia, IND B) was investigated for possible genetic modifiers. A germline mutation in the NF1 gene, c.2424InsCCTTCAC, and a germline GDNF variant R93W were found in this family.

- In this kindred, only members with both the paternally derived GDNF R93W and the maternally inherited NF1 mutation had megacolon.

- Such epistatic interaction between $N F 1$ and $G D N F$ is in keeping with functional cross talk of the RET and RAS pathways in a complex subcellular signalling network.

The first two authors contributed equally to this work. We are rateful to Drs L Taine, P Vergnes, S Gallet, and J-F Chateil for their contribution to investigating this family, to I Laurendeau and $\mathrm{M}$ Olivi for technical assistance, and to Dr D Récan and coworkers for establishing and maintaining lymphoblastoid cell lines. This work was supported by the Association pour la Recherche contre le Cancer (ARC) and the French Ministère de l'Enseignement Supérieur, de l'Education Nationale et de la Recherche, and the Association Française contre les Myopathies (AFM).

1 Riccardi VM. Neurofibromatosis - phenotype, natural history, and pathogenesis. 2nd ed. Baltimore: The Johns Hopkins University Press, 1992.

2 Stumpf DA, Alksne JF, Annegers JF, Brown SS, Conneally PM, Housman D, Leppert MF, Miller JP, Moss ML, Pileggi AJ, Rapin I, Strohman RC, Swanson LW, Zimmerman A, Drage JS, Elliott JM, Handelsman H, Martuza RL, Muenter MD, Mulvihill JJ, Myrianthopoulos NC, Rose M, Shakhashiri ZA, Stumpf DA, Bernstein MJ, Duncan P. Neurofibromatosis - conference statement. Arch Neurol 1988;45:575-8.

3 Martin GA, Viskochil D, Bollag G, McCabe PC, Crosier WJ, Haubruck H, Conroy L, Clark, R, O'Connell, P, Caw-
thon, RM. The GAP-related domain of the neurofibromathon, RM. The GAP-related domain of the neurofibromatosis type

4 Feig LA, Urano T, Cantor S. Evidence for a Ras/Ral signaling cascade. Trends Biochem Sci 1996;21:438-41.

5 Saul RA, Sturner RA, Burger PC. Hyperplasia of the myenteric plexus. Its association with early infantile megacolon and neurofibromatosis. Am f Dis Child 1982;136: 852-4.

6 Feinstat T, Tesluk H, Schuffler MD, Krishnamurthy S, Verlenden L, Gilles W, Frey C, Trudeau W. Megacolon and neurofibromatosis: a neuronal intestinal dysplasia - case report and review of the literature. Gastroenterology 1984;86:1573-9.

7 Clausen N, Andersson P, Tommerup N. Familial occurrence of neuroblastoma, von Recklinghausen's neurofibromatosis, Hirschsprung's aganglionosis and jaw-winking syndrome. Acta Paediatr Scand 1989;78:736-41.

8 Easton DF, Ponder MA, Huson SM, Ponder BAJ. An analysis of variation in expression of neurofibromatosis $(\mathrm{NF})$ type 1 (NF1): evidence for modifying genes. Am f Hum type 1 (NF1): evidence

9 Meier-Ruge WA, Brönnimann PB, Gambazzi F, Schmid PC, Schmidt CP, Stoss F. Histopathological criteria for intestinal neuronal dysplasia of the submucosal plexus (type B). Virchows Arch 1995;426:549-56

10 Bahuau M, Laurendeau I, Pelet A, Assouline B, Lamireau T, Taine L, Le Bail B, Vergnes P, Gallet S, Vidaud M, Lyonnet S, Lacombe D, Vidaud D. Tandem duplication within the neurofibromatosis type-1 gene (NF1) and reciprocal $\mathrm{t}(15 ; 16)(\mathrm{q} 26.3 ; \mathrm{q} 12.1)$ translocation in familial association of NF1 with intestinal neuronal dysplasia type B (IND B). F Med Genet 2000;37:146-50

11 Edery P, Lyonnet S, Mulligan LM, Pelet A, Dow E, Abel L, Holder S, Nihoul-Fékété C, Ponder BAJ, Munnich A Mutations of the RET proto-oncogene in Hirschsprung's disease. Nature 1994;367:378-80.

12 Romeo G, Ronchetto P, Luo Y, Barone V, Seri M, Ceccherini I, Pasini B, Bocciardi R, Lerone M, Kääriäinen $\mathrm{H}$, Martucciello G. Point mutations affecting the tyrosine kinase domain of the RET proto-oncogene in Hirschsprung's disease. Nature 1994;367:377-8.

13 Attié T, Pelet A, Edery P, Eng C, Mulligan LM, Amiel J, Boutrand L, Beldjord C, Nihoul-Fékété C, Munnich A, Ponder BAJ, Lyonnet S. Diversity of RET proto-oncogene mutations in familial and sporadic Hirschsprung disease. Hum Mol Genet 1995;4:1381-6.

14 Amiel J, Attié T, Jan D, Pelet A, Edery P, Bidaud C, Lacombe D, Tam P, Simeoni J, Flori E, Nihoul-Fékété C, Munnich A, Lyonnet S. Heterozygous endothelin receptor $\mathrm{B}$ (EDNRB) mutations in isolated Hirschsprung disease. Hum Mol Genet 1996;5:355-7.

15 Auricchio A, Casari G, Staiano A, Ballabio A. Endothelin-B receptor mutations in patients with isolated Hirschsprung disease from a non-inbred population. Hum Mol Genet 1996;5:351-4.

16 Kusafuka T, Wang Y, Puri P. Novel mutations of the endothelin-B receptor gene in isolated patients with Hirschsprung's disease. Hum Mol Genet 1996;5:347-9.

17 Bidaud C, Salomon R, Van Camp G, Pelet A, Attié T, Eng C, Bonduelle M, Amiel J, Nihoul-Fékété C, Willems PJ, Munnich A, Lyonnet S. Endothelin-3 gene mutations in isolated and syndromic Hirschsprung disease. Eur f Hum Genet 1997;5:247-51.

18 Barone V, Weber D, Luo Y, Brancolini V, Devoto M, Romeo $\mathrm{G}$. Exclusion of linkage between RET and neuronal intestinal dysplasia type B. Am 7 Med Genet 1996;62:195-8.

19 Amiel J, Salomon R, Attié T, Pelet A, Trang H, Mokhtari M, Gaultier C, Munnich A, Lyonnet S. Mutations of the RETGDNF signaling pathway in Ondine's curse. Am f Hum Genet 1998;62:715-17.

20 Angrist M, Bolk S, Halushka M, Lapchak PA, Chakravarti A. Germline mutations in glial cell line-derived neurotrophic factor (GDNF) and RET in a Hirschsprung disease patient. Nat Genet 1996;14:341-4.

21 Ivanchuk SM, Myers SM, Eng C, Mulligan LM. De novo mutation of GDNF, ligand of the RET/GDNFR-alpha receptor complex, in Hirschsprung disease. Hum Mol Genet 1996;5:2023-6.

22 Salomon R, Attié T, Pelet A, Bidaud C, Eng C, Amiel J, Sarnacki S, Goulet O, Ricour C, Nihoul-Fékété C, Munnich A, Lyonnet S. Germline mutations of the RET ligand GDNF are not sufficient to cause Hirschsprung disease. Nat Genet 1996;14:345-7.

23 Doray B, Salomon R, Amiel J, Pelet A, Touraine R, Billaud M, Attié T, Bachy B, Munnich A, Lyonnet S. Mutation of the RET ligand, neurturin, supports multigenic inheritance in Hirschsprung's disease. Hum Mol Genet 1998;7:144952.

24 Lin LFH, Doherty DH, Lile JD, Bektesh S, Collins F. GDNF: a glial cell line-derived neurotrophic factor for midbrain dopaminergic neurons. Science 1993;260:1130-2.

25 Woodward ER, Eng C, McMahon R, Voutilainen R, Affara NA, Ponder BA, Maher ER. Genetic predisposition to phaeochromocytoma: analysis of candidate genes GDNF, RET and VHL. Hum Mol Genet 1997;6:1051-6.

26 Krawczak M, Ball EV, Cooper DN. Neighboring-nucleotide effects on the rates of germ-line single-base-pair substitution in human genes. Am f Hum Genet 1998;63:474-88

27 Bohn MC. A commentary on glial cell line-derived neurotrophic factor (GDNF). From a glial secreted molecule to gene therapy. Biochem Pharmacol 1999;57:13542 .

28 Ramer MS, Priestly JV, McMahon SB. Functional regeneration of sensory axons into the adult spinal cord. Nature 2000;403:312-16.

29 Durbec P, Marcos-Gutierrez CV, Kilkenny C, Grigoriou M, Wartiowaara K, Suvanto P, Smith D, Ponder B, Costantini F, Saarma M, Sariola H, Pachnis V. GDNF signaling through the Ret receptor tyrosine kinase. Nature 1996;381: through

30 Treanor JJS, Goodman L, de Sauvage F, Stone DM, Poulsen KT, Beck CD, Gray C, Armanini MP, Pollock RA, Hefti F, Phillips HS, Goddard A, Moore MW, Buj-Bello A, Davies AM, Asai N, Takahashi M, Vandlen R, Henderson CE, Rosenthal A. Characterization of a multicomponent receptor for GDNF. Nature 1996;382:80-3.

31 Jing S, Wen D, Yu Y, Holst PL, Luo Y, Fang M, Tamir R, Antonio L, Hu Z, Cupples R, Louis JC, Hu S, Altrock BW, Fox GM. GDNF-induced activation of the Ret protein tyrosine kinase is mediated by GDNFR- $\alpha$, a novel receptor for GDNF. Cell 1996;85:1113-24.

32 van Weering DH, de Rooij J, Marte B, Downward J, Bos JL, Burgering BM. Protein kinase B activation and lamellipodium formation are independent phosphoinositide 3-kinase-mediated events differentially regulated by endogenous Ras. Mol Cell Biol 1998;18:1802-11.

33 Van Weering DHJ, Bos JL. Signal transduction by the tyrosine kinase Ret. Recent Results Cancer Res 1998;154:271-81.

4 Carson EB, McMahon M, Baylin SB, Nelkin BD. Ret gene silencing is associated with Raf-1-induced medullary thyroid carcinoma cell differentiation. Cancer Res 1995;55: 2048-52.

35 Chen H, Carson-Walter EB, Baylin SB, Nelkin BD, Ball DW. Differentiation of medullary thyroid cancer by C-Raf-1 silences expression of the neural transcription factor human achaete-scute homolog-1. Surgery 1996;120: 168-73.

36 Carson-Walter EB, Smith DP, Ponder BA, Baylin SB, Nelkin BD. Post-transcriptional silencing of RET occurs, but is not required, during raf-1 mediated differentiation of medullary thyroid carcinoma cells. Oncogene 1998;23:3676. 
7 Med Genet

2001;38:643-646

Biologia Generale e

Genetica Medica,

Università di Pavia,

Italy

R Clementi

C Danesino

Department of

Paediatric Haematology

and Oncology, University

Children Hospital,

Hamburg, Germany

U zur Stadt

G Janka

Istituto di Medicina

Molecolare, "Angelo

Nocivelli", Clinica

Pediatrica, Università

di Brescia, Italy

G Savoldi

L D Notarangelo

Clinica Pediatrica,

Università di Padova,

Italy

$S$ Varotto

Clinica Pediatrica, Università di Milano

Bicocca, Ospedale San

Gerardo, Monza, Italy

V Conter

Onco-Ematologia

Pediatrica, Ospedale

Pausilipon, Napoli, Italy

C De Fusco

Section of Experimental

Anaesthesiology,

University of Ulm,

Germany

M Schneider

Biometry and Clinical Epidemiology Service, IRCCS Policlinico San Matteo, Pavia, Italy

C Klersy

Clinica Pediatrica, IRCCS Policlinico San Matteo, Pavia, Italy

M Aricò

Correspondence to:

Dr Danesino, CP 217, 27100

Pavia, Italy

cidi@unipv.it

37 Gutmann DH, Collins FS. Von Recklinghausen neurofibromatosis. In: Scriver CR, Beaudet AL, Sly WS, Valle D, bromatosis. In. Scriver CR, Beaudet AL, Sly WS, Valle D, eds. The metabolic and molecular bases of inherited diseases.

38 Sánchez MP, Silos-Santiago I, Frisen J, He B, Lira SA, Barbacid $M$. Renal agenesis and the absence of enteric neurons in mice lacking GDNF. Nature 1996;382:70-3.

39 Pichel JG, Shen L, Sheng HZ, Granholm AC, Drago J, Grinberg A, Lee EJ, Huang SP, Saarma M, Hoffer BJ, Sariola H, Westphal $H$. Defects in enteric innervation and kidney development in mice lacking GDNF. Nature 1996;382:73-6.

40 Moore MW, Klein RD, Farinas I, Sauer H, Armanini M, Phillips H, Reichardt LF, Ryan AM, Carver-Moore K, Rosenthal A. Renal and neuronal abnormalities in mice lacking GDNF. Nature 1996;382:76-9.

41 Brannan CI, Perkins AS, Vogel KS, Ratner N, Nordlund ML, Reid SW, Buchberg AM, Jenkins NA, Parada LF, ML, Reid SW, Buchberg AM, Jenkins NA, Parada LF, Copeland NG. Targeted disruption of the neurofibromatois type-1 gene leads to developmental abnormalities in heart and various neural crest-derived tissues. Genes Dev

2 Jacks T, Shih TS, Schmitt EM, Bronson RT, Bernards A, Weinberg RA. Tumour predisposition in mice heterozygous for a targeted mutation in Nf1. Nat Genet 1994;7:353-61.

43 Houlston RS, Tomlinson IP. Modifier genes in humans: strategies for identification. Eur F Hum Genet 1998;6:80-8.

44 Puffenberger EG, Hosoda K, Washington SS, Nakao K, deWit D, Yanagisawa M, Chakravarti A. A missense mutation of the endothelin-B receptor gene in multigenic Hirschsprung's disease. Cell 1994;79:1257-66.

45 Bolk S, Pelet A, Hofstra RMW, Angrist M, Salomon R, Croaker D, Buys CHCM, Lyonnet S, Chakravarti A. A

human model for multigenic inheritance: phenotypic expression in Hirschsprung disease requires both the RET gene and a new 9q31 locus. Proc Natl Acad Sci USA 2000; 97:268-73.

46 Ricciardone MD, Özçelik T, Cevher B, Özdag H, Tuncer M, Gürgey A, Uzunalimoglu O, Çetinkaya H, Tanyeli A, Erken E, Ozturk M. Human MLH1 deficiency predisposes to hematological malignancy and neurofibromatosis type 1 . Cancer Res 1999;59:290-3.

47 Wang Q, Lasset C, Desseigne F, Frappaz D, Bergeron C, Navarro C, Ruano E, Puisieux A. Neurofibromatosis and early onset of cancers in hMLH1-deficient children. Cancer Res 1999;59:294-97.

48 Ottini L, Esposito DL, Richetta A, Carlesimo M, Palmirotta R, Veri MC, Battista P, Frati L, Caramia FG, Calvieri S, Cama A, Mariani-Costantini R. Alterations of microsatellites in neurofibromas of von Recklinghausen's disease. Cancer Res 1995;55:5677-80.

49 Cichowski K, Shih TS, Schmitt E, Santiago S, Reilly K, McLaughlin ME, Bronson RT, Jacks T. Mouse model of tumor development in neurofibromatosis type 1 . Science 1999;286:2172-6

50 Vogel KS, Klesse LJ, Velasco-Miguel S, Meyers K, Rushing EJ, Parada LF. Mouse tumor model for neurofibromatosis type 1. Science 1999;286:2176-9.

51 Bahuau M, Houdayer C, Assouline B, Blanchet-Bardon C, Le Merrer M, Lyonnet S, Giraud S, Récan D, Lakhdar H, Vidaud M, Vidaud D. Novel recurrent nonsense mutation causing neurofibromatosis type 1 (NF1) in a family segregating both NF1 and Noonan syndrome. Am f Med Genet $1998 ; 75: 265-72$

\section{Six novel mutations in the $P R F 1$ gene in children with haemophagocytic lymphohistiocytosis}

Rita Clementi, Udo zur Stadt, Gianfranco Savoldi, Stefania Varotto, Valentino Conter, Carmela De Fusco, Luigi D Notarangelo, Marion Schneider, Catherine Klersy, Gritta Janka, Cesare Danesino, Maurizio Aricò

EDITOR - The histiocytoses represent a heterogeneous group of disorders including both hereditary and sporadic forms. The familial form of haemophagocytic lymphohistiocytosis $(\mathrm{HLH})$ was originally described by Farquhar and Claireaux ${ }^{1}$ in 1952. The main features of this disease are fever, hepatosplenomegaly, cytopenia, hypertriglyceridaemia, hypofibrinogenaemia, and central nervous system involvement. ${ }^{23}$ Haemophagocytosis is observed at presentation or later during the course of the disease in most patients. In 1991, the Histiocyte Society defined its diagnostic criteria however, the differential diagnosis of HLH from other disorders may remain problematical, especially in patients without familial recurrence. Linkage of the disease gene to an approximately $7.8 \mathrm{cM}$ region between markers D9S1867 and D9S1790 at 9q21.3-22 was identified by homozygosity mapping in four inbred families with HLH of Pakistani descent. ${ }^{5}$ Also, linkage analysis of a group of 17 families with HLH indicated mapping of a locus linked to HLH to the proximal region of the long arm of chromosome 10 in the $10 \mathrm{q} 21-22$ region in 10 families but not in the remaining seven, providing evidence for genetic heterogeneity of this condition. ${ }^{6-9}$ While no further cases of HLH linked to the 9q21.3-22 locus have been reported, recently Stepp et $a l^{10}$ identified nine different mutations, three nonsense and six missense, in the two coding exons of the perforin 1 gene (PRF1) in a group of eight unrelated patients, providing the first evidence for a disease related to
PRF $1 .{ }^{10}$ Perforin is an important mediator of lymphocyte cytotoxicity in a pathway independent from the Fas mediated apoptotic machinery. Thus, PRF1 mutations may affect cellular cytotoxicity, resulting in impaired antiviral defence and dysregulation of the apoptotic mechanisms involved in regulation of the immune response. ${ }^{11}$

We report six novel mutations and also confirm three additional mutations which had been previously reported. They were observed in 10 patients of Italian, Turkish, and Ghanaian origin.

\section{Materials and methods}

We studied 10 families in which the index case fulfilled the diagnostic criteria for $\mathrm{HLH}^{4}$ and a careful family history was collected. Consanguinity was investigated and when not evident the parents were asked to obtain further information including the birth place of their ancestors. Clinical data were obtained from the attending physicians and from thorough evaluation of records.

Natural killer activity was determined in one of the two reference laboratories (Dr Rita Maccario, Pavia, Italy and Professor Marion Schneider, Ulm, Germany) as previously reported. ${ }^{12} 13$ Molecular analyses were performed as reported by Stepp et al, ${ }^{10}$ sequencing exons 2 and 3 of the PRF1 gene. The sequences obtained were compared to the reported gene structure (gene number 190339 NCBI) using the BLASTN program (http:// www.ncbi.nlm.nih.gov/BLAST). In order to 
Table 1 Details of mutations in the perforin 1 gene observed in 10 patients with HLH

\begin{tabular}{llllllll}
\hline Case & $\begin{array}{l}\text { Ethnic } \\
\text { origin }\end{array}$ & $\star \star \star$ & Nucleotide & Exon & Mutation & Predicted effect & Domain \\
\hline 1 & Ghana & $\star \star$ & 50 & 2 & del t $\neq$ & L 17 Fs and stop & \\
2 & Italy & $\star \star$ & 283 & 2 & t $>$ c & W 94 R & \\
3 & Italy & $\star \star$ & 657 & 3 & c $>$ a & Y 219 stop & 2nd TM \\
4 & Italy & $\star \star$ & 658 & 3 & $\mathrm{~g}>\mathrm{a}$ & G 220 S & 2nd TM \\
5 & Italy & $\star$ & 662 & 3 & $\mathrm{c}>\mathrm{t}$ & T221I & 2nd TM \\
& & $\star$ & 673 & 3 & $\mathrm{c}>\mathrm{t} \neq$ & R225W & 2nd TM \\
6 & Italy & $\star$ & 694 & 3 & $\mathrm{c}>\mathrm{t}$ & R 232 C & \\
& & $\star$ & 1182 & 3 & ins t & G 394 Fs and stop & EGF-like \\
7 & Turkey & $\star \star$ & 1122 & 3 & $\mathrm{~g}>\mathrm{a} \neq$ & W 374 stop & EGF-like \\
8 & Turkey & $\star \star$ & 1122 & 3 & $\mathrm{~g}>\mathrm{a}$ & W 374 stop & EGF-like \\
$9 \dagger$ & Turkey & $\star \star$ & 1122 & 3 & $\mathrm{~g}>\mathrm{a}$ & W 374 stop & EGF-like \\
10 & Turkey & $\star \star$ & 1122 & 3 & $\mathrm{~g}>\mathrm{a}$ & W 374 stop & EGF-like \\
\hline
\end{tabular}

$\star / \star \star=$ heterozygous/homozygous mutation.

$\dagger$ The same mutation was also observed in his brother with an identical clinical picture.

$\ddagger$ These mutations have been previously described by Stepp et al. ${ }^{10}$

2nd $\mathrm{TM}=$ second transmembrane domain.

EGF-like $=$ epidermal growth factor-like domain

Fs $=$ frameshift. parental consanguinity. Thus, eight of the 10 patients had related (or very probably related) parents. In 231 cases enrolled in the International HLH Registry ${ }^{3}$ (M Aricò, unpublished data) with information on this, 56 $(23.2 \%)$ had related parents. Among the 10 patients with PRF1 mutations, seven had one or more sibs. Of a total of 21 sibs, six were affected. Four of 10 patients had one or more affected sib.

The clinical and laboratory features of the 10 patients with PRF1 mutations fit the diagnostic criteria for HLH (fever, splenomegaly, cytopenia, hypertriglyceridaemia or hypofibrinogenaemia, and haemophagocytosis). ${ }^{4}$ Additional features, like CNS alterations, skin rash, lymphadenomegaly, and oedema, were also present in some cases (table 2). Eight of the 10 patients with PRF1 defects developed HLH by the third month of life (median 2.2 months). This age was lower than that of our additional 21 patients in whom no PRF1 mutations were found (median 5 months, range 0.5-86). In 209 cases enrolled in the Registry with information on this, the median age at diagnosis was 5.3 months (range $0-254$ months) $(\mathrm{p}=0.05) ; 32 \%$ were diagnosed within three months and $80 \%$ within two years. One of our patients with PRF1 mutations remained asymptomatic until the age of 6 years when he developed full blown HLH. Among the Registry patients, $17(8.1 \%)$ presented when older than 5 years, with an estimated risk of being diagnosed when older than 5 years of $8.1 \%$ (SE 1.8).

Although difficult to quantify, all patients had a very severe presentation and clinical course. They had to be aggressively treated and showed early relapse after disease control was initially achieved. All six patients who underwent BMT remain asymptomatic.

\section{Results}

We have identified six novel mutations in the PRF1 gene; three additional mutations that we observed had been previously reported by Stepp et al. ${ }^{10}$ Two novel mutations (C657A in case 3 and 1182 ins $T$ in case 6) (table 1) introduced a stop codon in the sequence which resulted in a truncated protein. The other novel mutations (T283C in case 2, G658A in case 4, $\mathrm{C} 662 \mathrm{~T}$ in case 5 , and $\mathrm{C} 694 \mathrm{~T}$ in case 6) caused an amino acid change. The mutations we observed are scattered along exons 2 and 3 without any obvious clustering. Four mutations were located in the second transmembrane domain while two occurred within or close to the EGF-like domain of the protein. ${ }^{14}$ It is remarkable that all the four patients of Turkish origin had the same mutation, G1122A. In 21 additional caucasian patients with HLH a mutation was not found. In particular, none of the patients of German origin from this group harboured the mutation ${ }^{9}$ (zur Stadt et al, manuscript in preparation).

Parental consanguinity was documented in five families and was very likely in three additional families, in which the ancestors originated from the same small villages or geographical regions. These patients (cases 1, 2 , and 4 , tables 1 and 2) were homozygous for loci D10S537 and D10S676, thus supporting

\section{Discussion}

We have described six novel mutations in the PRF1 gene in children with HLH; two introduced a premature stop codon in the sequence which resulted in a truncated protein, while the other four caused an amino acid change. Caution should be exercised in interpreting a missense mutation which causes an amino acid change to be responsible for the phism. In our cases, these mutations modified a conserved amino acid and were never found in other subjects tested. These mutations were scattered along exons 2 and 3 without any obvious clustering, in keeping with the previous report by Stepp et al..$^{10}$

The same mutation, G1122A, was observed in the four patients of Turkish origin. This mutation had been observed twice by Stepp et $a l^{10}$ in patients of unspecified origin and was also reported in patients of Turkish origin. ${ }^{15}$ Altogether these data indicate that, at least in a subset of patients of Turkish origin with HLH, a founder effect is possible. Further analysis of affected children from the same geographical region should be undertaken to confirm this. No founder effect can be hypothesised in patients of Italian origin. disease and is not just a population polymor- 


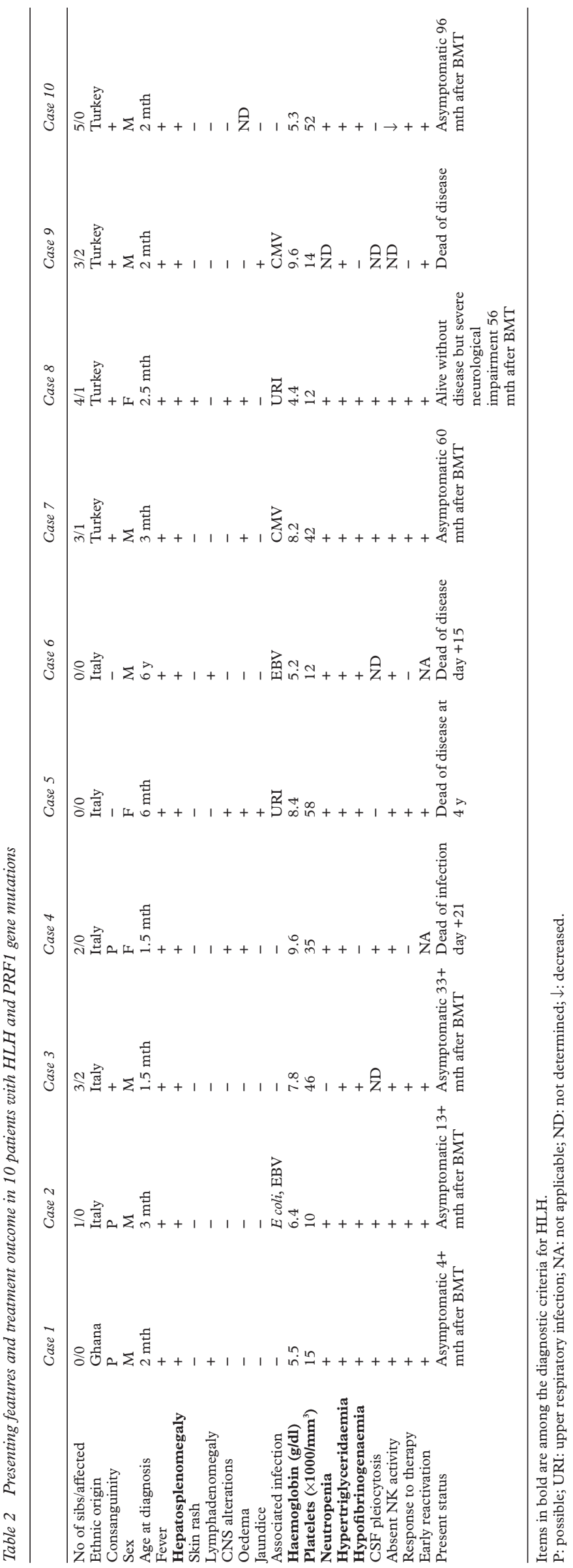

In this small series of patients with HLH and PRF1 mutations, each patient presented the symptoms which form the diagnostic criteria for HLH, as well as some of the less frequent abnormalities (table 2). Comparison with the additional 21 patients in whom PRF1 mutations were not found confirms that no striking difference based on clinical grounds is evident between the two groups. The presence of an associated infection emphasises the triggering role of common pathogens and confirms that infection associated with HLH is common in patients with PRF1 mutations. All these mutations are very likely to cause a severe impairment of perforin function and in fact NK activity was severely impaired or absent in all of these patients.

Delayed onset of HLH, beyond five years, was reported in $8 \%$ of the Registry patients and was also documented in one of our patients with PRF1 mutations (case 6), who remained asymptomatic until the age of 6 years. Since patients of relatively older age, although fitting the diagnostic criteria, have often been thought to be potentially misdiagnosed, this information is relevant in that it confirms that, at least in a minority of cases, HLH should be suspected even beyond the usual age range. ${ }^{16}$ Whether HLH resulting from PRF1 mutation may present during adulthood remains an issue to be addressed.

All 10 patients with PRF1 mutations had a very severe presentation and clinical course. In some cases, HLH, either apparently sporadic or familial, may present with an incomplete picture and/or a mild course, including repeated episodes of remission, which may be controlled with minimal or intermittent treatment, and may even undergo spontaneous remission at least for a certain time, occasionally up to some years. This was not the case in our patients, all of whom had to be treated aggressively, showed early relapse after control of the disease was initially achieved, and were considered candidates for early BMT. All six patients who underwent BMT remain asymptomatic, confirming the unique potential of $\mathrm{BMT}$ for long lasting remission and even cure in HLH patients with PRF1 mutations. ${ }^{17-19}$

Our findings underline the need to redefine the diagnostic approach to HLH in children. In particular, evaluation of NK activity, which was severely impaired in all but one (low-normal) case with PRF1 mutations, should be included in the clinical diagnostic work up of HLH.

In conclusion, our data confirm that PRF1 mutations can occur throughout the coding region of exons 2 and 3 and suggest a founder effect for HLH in Turkey but not in Italy. HLH resulting from PRF1 mutation usually presents in infancy but occasionally may occur in older patients. Identification of a genetic defect in patients with HLH has diagnostic, prognostic, and therapeutic implications and should be pursued whenever possible. Despite frequent concordance of the age at onset within each family, asymptomatic sibs (including potential stem cells donors) cannot be safely defined as unaffected, unless their genetic status for HLH is assessed. Lack of this information may risk 
BMT from an affected donor in a presymptomatic phase. $^{18}$ Identification of PRF1 gene mutations allows diagnostic confirmation, correct genotype determination in the family, confirmed indication for BMT even from alternative donors, proper genetic counselling, and prenatal diagnosis. A detailed genotypephenotype correlation cannot be performed until a much larger number of patients with and without PRF1 mutations are identified.

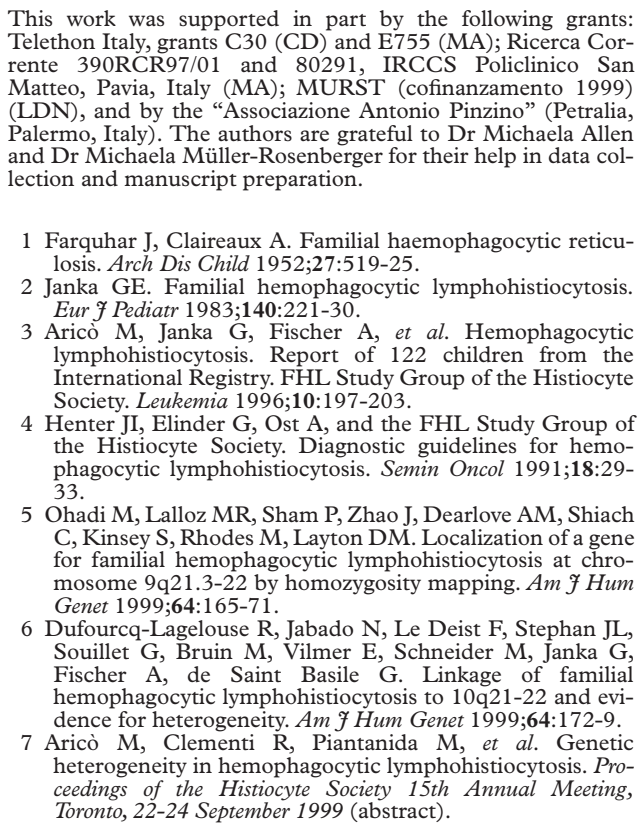

Farquhar J, Claireaux A. Familial haemophagocytic reticulosis. Arch Dis Child 1952;27:519-25.

2 Janka GE. Familial hemophagocytic lymphohistiocytosis. Eur 7 Pediatr 1983;140:221-30.

3 Aricò M, Janka G, Fischer A, et al. Hemophagocytic lymphohistiocytosis. Report of 122 children from the International Registry. FHL Study Group of the Histiocyte Society. Leukemia 1996;10:197-203.

4 Henter JI, Elinder G, Ost A, and the FHL Study Group of the Histiocyte Society. Diagnostic guidelines for hemophagocytic lymphohistiocytosis. Semin Oncol 1991;18:29 33.

5 Ohadi M, Lalloz MR, Sham P, Zhao J, Dearlove AM, Shiach C, Kinsey S, Rhodes M, Layton DM. Localization of a gene for familial hemophagocytic lymphohistiocytosis at chromosome 9q21.3-22 by homozygosity mapping. Am f Hum Genet 1999;64:165-71.

6 Dufourcq-Lagelouse R, Jabado N, Le Deist F, Stephan JL, Souillet G, Bruin M, Vilmer E, Schneider M, Janka G, Fischer A, de Saint Basile G. Linkage of familial hemophagocytic lymphohistiocytosis to 10q21-22 and evidence for heterogeneity. Am f Hum Genet 1999;64:172-9.

7 Aricò M, Clementi R, Piantanida M, et al. Genetic Arico M, Clementi R, Piantanida M, et al. Genetic
heterogeneity in hemophagocytic lymphohistiocytosis. Proceedings of the Histiocyte Society 15th Annual Meeting, ceedings of the Histiocyte Society 15th
Toronto, 22-24 September 1999 (abstract).

8 Graham GE, Graham LM, Bridge PJ, Maclaren LD, Wolff JEA, Coppes MJ, Egeler RM. Further evidence for genetic heterogeneity in familial hemophagocytic lymphohistiocytosis. Pediatr Res 2000;48:227-32.

9 zur Stadt U, Kabisch H, Janka G, Schneider M. Mutational analysis of the perforin gene and NK-cell function in hemophagocytic lymphohistiocytosis. Proceedings of the Histiocyte Society 16th Anmul Meting, Amsterdam, 29 September-2 October 20 000 (abstract)

10 Stepp SE, Dufourcq-Lagelouse R, Le Deist F, Bhawan S, Certain S, Mathew PA, Henter JI, Bennett M, Fischer A, de Saint Basile G, Kumar V. Perforin gene defects in familial hemophagocytic lymphohistiocytosis. Science 1999;286: 1957-9.

11 Aricò M, Nespoli L, Maccario R, Montagna D, Bonetti F, Caselli D, Burgio GR. Natural cytotoxicity impairment in familial haemophagocytic lymphohistiocytosis. Arch Dis Child 1988;63:292-6.

12 Schneider EM, Pawelec G, Shi LR, Wernet P. A novel type of human $\mathrm{T}$ cell clones with highly potent natural killer-like cytotoxicity divorced from large granular lymphocyte morphology. F Immunol 1984;133:173-9.

13 Ericson K, Petterson T, Nordenmskjold M, Henter JI. Spectrum of mutations in the perforin gene in familial hemophagocytic lymphohistiocytosis. Proceedings of the Histiocyte Society 16th Annual Meeting, Amsterdam, 29 September-2 October 2000 (abstract)

14 Liu CC, Walsh CM, Young JDE. Perforin: structure and function. Immunol Today 1995;16:194-201.

15 Allen M, De Fusco C, Vilmer E, Clementi R, Conter V, Danesino C, Janka G, Aricò M. Familial hemophagocytic lymphohistiocytosis: how late can the onset be? Hematologica $2001 ; 86: 455-9$.

6 Fischer A, Cerf Bensussan N, Blanche S, LeDeist F, Bremard-Oury C, Leverger G, Schaison G, Durandy A, Griscelli C. Allogeneic bone marrow transplantation for erythrophagocytic lymphohistiocytosis. F Pediatr 1986;108: 267-70.

17 Blanche S, Caniglia M, Girault D, Landman J, Griscelli C, Fischer A. Treatment of hemophagocytic lymphohistiocytosis with chemotherapy and bone marrow transplantation: a single-center study of 22 patients. Blood 1991;78:51-4

18 Durken M, Horstmann M, Bieling P, Erttmann R, Kabisch H, Loliger C, Schneider EM, Hellwege HH, Kruger W, Kroger N, Zander AR, Janka GE. Improved outcome in haemophagocytic lymphohistiocytosis after bone marrow transplantation from related and unrelated donors: a sinstantation from . $1999 ; 106: 1052-8$
7 Med Genet

2001;38:646-647

\section{Department of \\ Paediatrics and \\ Paediatric Surgery, \\ Hammersmith \\ Hospital, Du Cane \\ Road, London \\ W12 0HS, UK \\ J P Boardman \\ N J Robertson \\ K Lakhoo}

Medical Genetics Unit, St George's Hospital Medical School,

Cranmer Terrace, London SW17 0RE, UK P Syrris

N Carter

Kennedy-Galton Centre, Medical and Community Genetics,

North West London Hospitals NHS Trust, Watford Road, Harrow

HA1 3UJ, UK

S E Holder

Correspondence to:

Dr Holder, s.holder@ic.ac.uk

\title{
A novel mutation in the endothelin $B$ receptor gene in a patient with Shah-Waardenburg syndrome and Down syndrome
}

\author{
J P Boardman, P Syrris, S E Holder, N J Robertson, N Carter, K Lakhoo
}

EDITOR-A case of Down syndrome, total gut Hirschsprung disease (HSCR), and segmental hypopigmentation is described in a neonate presenting with bowel obstruction. In addition to having trisomy 21 , this patient was homozygous for a novel mutation in the endothelin $\mathrm{B}$ receptor $(E D N R B)$ gene.

A term female infant with karyotype $47, \mathrm{XX},+21$ presented on day 3 of life with bowel obstruction. She was of Somali origin and had large areas of segmental hypopigmentation affecting the left side of the face and trunk, the left upper limb, including the hair follicles, and had white scalp hair. At laparotomy she had an annular pancreas, duodenal web, and inspissated meconium in the ileum and colon, for which she underwent a duodenoduodenostomy. Histology of the rectal biopsy and appendix was inconclusive at this stage. Intestinal obstruction persisted and on day 20 she underwent a further laparotomy, which showed breakdown of the original anastomosis. Intraoperative frozen sections showed complete aganglionosis throughout the entire large and small bowel, sparing only the stomach and oesophagus; this is incompatible with life. An ileostomy was fashioned, intensive care was withdrawn, and the baby died the following morning. Necropsy confirmed total bowel aganglionosis. Her parents are not known to be consanguineous and there is no history of pigmentary disturbance or bowel disease in either them or her five sibs. Family genetic studies and clinical photographs were declined; a hearing assessment was precluded by her being ventilated and sedated for the duration of her life.

Shah-Waardenburg syndrome describes the association of HSCR with Waardenburg syndrome, and consists of deafness, pigmentary disturbance, and aganglionic megacolon. It is the result of defective development of two neural 


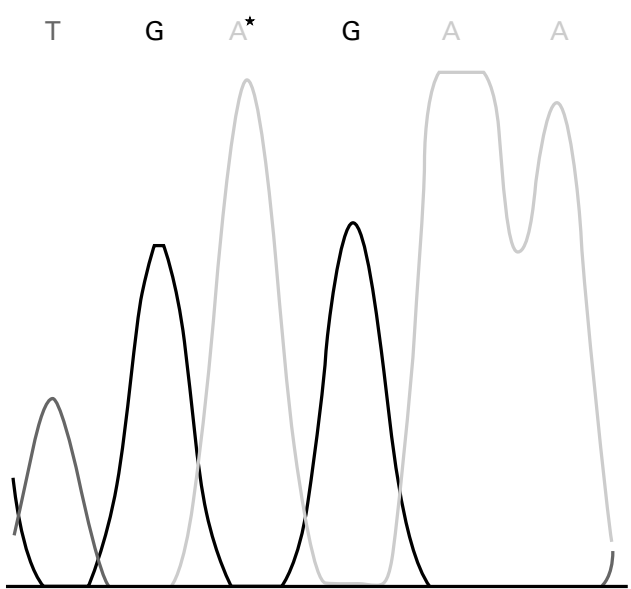

Figure 1 Sequence analysis showing nucleotides corresponding to codon 186 of the EDNRB gene. A DNA sample from the infant was used as a template in a PCR reaction in order to amplify exon 2 of the EDNRB gene. The resulting product was subsequently sequenced using standard methods. The electropherogram shows the presence of the Gly/Arg mutation at codon 186. The mutated nucleotide at codon $186\left(A^{\star} G A\right)$ is marked with $\left(^{\star}\right)$ to distinguish it from the wild type sequence $(G G A)$.

crest derived cell lineages: epidermal melanocytes and enterocytes.

A number of susceptibility genes for HSCR alone have been identified from the $5 \%$ of HSCR cases in whom there is an associated chromosomal or hereditary disorder and from HSCR affected kindreds. ${ }^{1}$ Susceptibility to Shah-Waardenburg syndrome is conferred by mutations in three genes, the endothelin B receptor $(E D N R B)$ gene at $13 \mathrm{q} 22$, its ligand the endothelin-3 gene (EDN3) at 20q13.2$13.3,{ }^{2}$ and in the SOX10 gene at $22 \mathrm{q} 13 .{ }^{3}$

All exons of the EDNRB gene were amplified by polymerase chain reaction (PCR), and PCR products were sequenced using standard methods on a ABI PRISM 377 DNA sequencer. ${ }^{24}$ This infant appeared to be homozygous for a novel missense mutation in exon 2 (codon 186, GGA-AGA) of the EDNRB gene, a mutation that leads to the substitution of glycine with arginine (fig 1). As the family declined further genetic studies, it is not possible to rule out hemizygosity or disomy in this patient.

The EDNRB gene codes for a $\mathrm{G}$ protein coupled transmembrane receptor protein which is necessary for the development of enteric neurones and epidermal melanocytes. The receptor ligand is endothelin-3, and mutations in this axis in both rodent models and humans result in a phenotypic spectrum comprising HSCR and pigmentary abnormalities. $^{56}$ The Gly186Arg mutation is located in the third transmembrane domain of the endothelin-B receptor and disrupts receptor function, suggested by the finding that several other mutations in the transmembrane domains of the protein are known to cause a phenotype of aganglionosis and hypopigmentation; the human manifestations are the spectrum of Shah-Waardenburg phenotypes. ${ }^{7}$ The exact position of the mutation in the homozygous state is likely to produce the pleiotropic features observed in these patients.

There are case reports of patients with Down syndrome in association with both HSCR and/or Shah-Waardenburg determining genes. ${ }^{8}{ }^{9}$ However, this patient had the coexistence of Down syndrome and a novel homozygous mutation of the EDNRB gene. This case emphasises that although HSCR has a well recognised association with Down syndrome, other causes of HSCR should be considered. Mutation analysis of known susceptibility genes might be helpful in cases of long segment HSCR, especially in those patients with pigmentary abnormalities and those with a positive family history of bowel dysfunction.

1 Kusafuka T, Puri P. Genetic aspects of Hirschsprung's disease. Semin Pediatr Surg 1998;7:148-55.

2 Kusafuka T, Wang Y, Puri P. Mutation analysis of the RET, the endothelin-B receptor, and the endothelin-3 genes in sporadic cases of Hirschsprung's disease. 7 Pediatr Surg 1997;32:501-4.

3 Pingault V, Bondurand N, Kuhlbrodt K, Goerich D, Préhu M, Puliti A, Herbarth B, Hermans-Borgmeyer I, Legius E, Matthijs G, Amiel J, Lyonnet S, Ceccherini R, ClaytonSmith J, Read A, Wegner M, Goossens M. SOX10 Smith J, Read A, Wegner M, Goossens M. SOX10
mutations in patients with Waardenburg-Hirschsprung mutations in patients with Waa
disease. Nat Genet 1998; 18:171-3.

4 Spritz RA, Giebel LB, Holmes SA. Dominant negative and loss of function mutations of the c-kit (mast/stem cell growth factor receptor) proto-oncogene in human piebaldism. Am f Hum Genet 1992;50:261-9.

5 Moore SW, Johnson AG. Hirschsprung's disease: genetic and functional associations of Down's and Waardenburg syndromes. Semin Pediatr Surg 1998;7:156-61.

6 Chakravarti A. Endothelin receptor mediated signalling in Hirschsprung disease. Hum Mol Genet 1996;5:303-7.

7 Attié T, Till M, Pelet A, Amiel J, Edery P, Boutrand L, Munnich A, Lyonnet S. Mutation of the endothelinreceptor B gene in Waardenburg-Hirschsprung disease. receptor B gene in Waarden

8 Sakai T, Wakizaka A, Nirasawa Y, Ito Y. Point nucleotide changes in both the RET proto-oncogene and the endothelin B receptor gene in a Hirschsprung disease patient associated with Down syndrome. Tohoku F Exp Med 1999;187: 43-7.

9 Salomon R, Attié T, Pelet A, Bidaud C, Eng C, Amiel J, Sarnacki S, Goulet O, Ricour C, Nihoul-Fékété C, Munnich A, Lyonnet S. Germline mutations of the RET ligand GDNF are not sufficient to cause Hirschsprung disease. Nat Genet 1996;14:345-7.

\section{Standing Committee on Human Cytogenetic Nomenclature 2001-2006}

Elections for the Standing Committee on Human Cytogenetic Nomenclature were held at the 10th International Congress of Human Genetics in Vienna, Austria, on 16 June 2001. The following members were elected for the period 2001-2006: Niels Tommerup (Denmark) (Chairman), Lynda Campbell (Australia), Christine Harrison (UK), David Ledbetter (USA), Albert Schinzel (Switzerland), Lisa Shaffer (USA), Angela Vianna-Morgante (Brazil). Issues regarding human cytogenetic nomenclature can be addressed to any member of the Committee. 